Portland State University

PDXScholar

Spring 6-2-2014

\title{
Understanding Biliteracy: Exploring the Lived Experiences of Bilingual Reading Specialists
}

Tatiana Margarita Cevallos

Portland State University

Follow this and additional works at: https://pdxscholar.library.pdx.edu/open_access_etds

Part of the Bilingual, Multilingual, and Multicultural Education Commons, and the Pre-Elementary, Early Childhood, Kindergarten Teacher Education Commons

Let us know how access to this document benefits you.

\section{Recommended Citation}

Cevallos, Tatiana Margarita, "Understanding Biliteracy: Exploring the Lived Experiences of Bilingual Reading Specialists" (2014). Dissertations and Theses. Paper 1790.

https://doi.org/10.15760/etd.1789

This Dissertation is brought to you for free and open access. It has been accepted for inclusion in Dissertations and Theses by an authorized administrator of PDXScholar. Please contact us if we can make this document more accessible: pdxscholar@pdx.edu. 
Understanding Biliteracy: Exploring the Lived Experiences of Bilingual Reading Specialists

by

Tatiana Margarita Cevallos

A dissertation submitted in partial fulfillment of the requirements for the degree of

\title{
Doctor of Education
}

in

Educational Leadership: Curriculum \& Instruction

\begin{abstract}
Dissertation Committee: Emily de la Cruz, Chair Esperanza De La Vega

Samuel Henry

Susan Conrad
\end{abstract}

Portland State University 2014 
(C) 2014 Tatiana Margarita Cevallos 


\begin{abstract}
Over the past 20 years, the United States has seen a rapid increase in school age students entering PK-12 schools for whom English is not their primary home language. These students are known as English learners (ELs). In Oregon, 77\% of ELs speak Spanish and constitute the largest minority group, $21 \%$ of the total K-12 student enrollment in 2011-2012. With such potential for bilingualism in schools, bilingual teachers should be prepared to teach biliteracy effectively, especially in the early school years when students learn to read. There is an increasing demand for bilingual teachers in Oregon each year to teach in bilingual programs, particularly at the primary grade levels. However, for the most part, the emphasis of instruction and teacher preparation is on developing student English skills rather than supporting bilingualism (Flores, Sheets, \& Clark, 2011; Macedo, Dendrinos, \& Gounari, 2003; Wink, 2005).

There is a need in Oregon to effectively prepare bilingual teachers who can help Spanish-speaking students develop biliteracy skills in the early grades. The purpose of this qualitative phenomenological study was to explore in depth the lived experiences among Oregon bilingual reading specialists in relation to biliteracy. The research question was "How do bilingual reading specialists understand the phenomena of teaching biliteracy to bilingual students?" Three themes emerged from the interviews conducted: collaboration, language and caring. The insights gained from the lived experiences of bilingual reading specialists can allow teacher educators, school district personnel, and state policy makers to better understand the phenomenon of developing biliteracy and change the way we prepare bilingual teachers in Oregon regarding
\end{abstract}


biliteracy pedagogy. Recommendations are offered for stakeholders, such as the need to include courses in biliteracy as part of the initial teaching license, deliver courses in Spanish, and provide practicum experiences that prepare bilingual teachers and reading specialists to collaborate with colleagues and families. Also, it is important that some of the strategies identified at the state level as part of the English Learner Strategic Plan specifically focus on biliteracy and dual language programs. 
Dedication

A mi hijo Isaac.

To my son Isaac. 


\section{Acknowledgments}

This journey has been filled with learning, joy, challenges and long days. I first want to thank God for opening every door for my studies and work. Dios guided me and steered me into a learning journey, both as student and teacher.

Next, I want to thank my family for always supporting and encouraging me.

I would also like to thank my advisor, Dr. Emily de la Cruz, and my dissertation committee: Dr. Esperanza de la Vega, Dr. Samuel Henry, and Dr. Susan Conrad. Thank you for challenging me, guiding me and encouraging me to explore qualitative research.

I also want to thank the participants in this study. I am honored to have worked with you and learned from you as you openly and honestly shared your experiences. I am excited and inspired to continue researching in this area.

I want to thank my friends and colleagues, Carol, Becky, Brenda, Susanna, Ginny, Linda, Terry, David and Paulina who have encouraged me and supported me in so many ways along this journey.

Last, but not least, I want to thank my husband, Derek, for his support and for teaching me to write in English. 
Table of Contents

Page

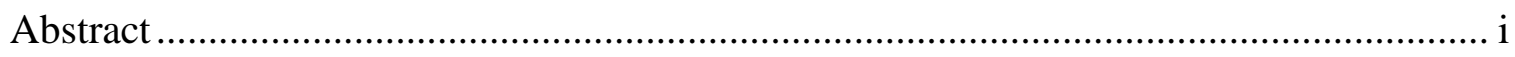

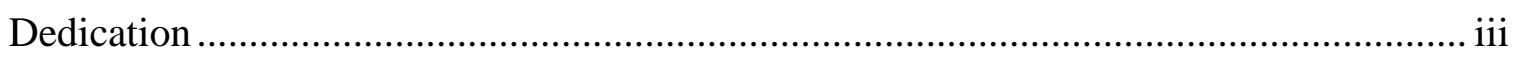

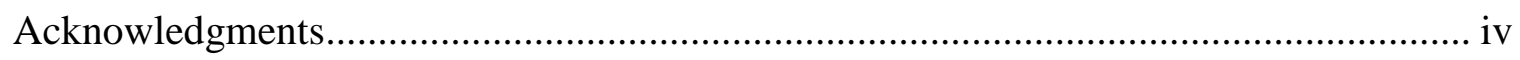

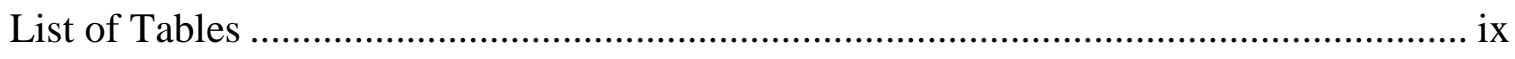

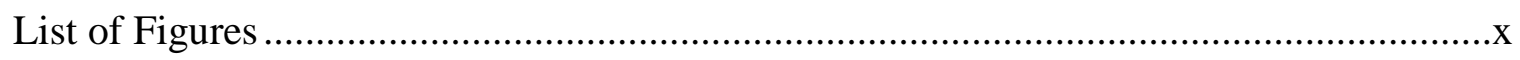

Chapter One

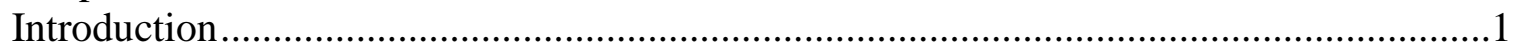

Definition of Terms.....................................................................................

Demographic Trends in Schools ............................................................

Schools' Approach to Bilingualism ...........................................................

- Personal Interest in Biliteracy Teacher Preparation...........................................11

Reading Endorsement Program With Emphasis in Biliteracy ............................12

Statement of Problem............................................................................. 13

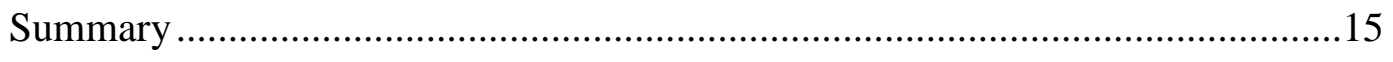

Chapter Two

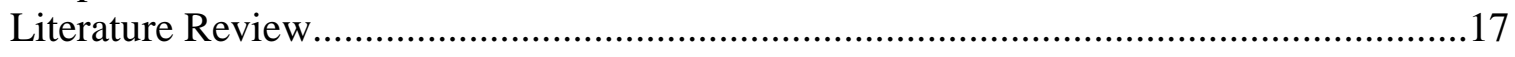

Education of Minority Populations From a Critical Pedagogy Perspective ..........18

Subtractive Bilingualism Frames Teacher Preparation in Oregon ......................21

Critical Pedagogy Approach to Bilingual Teacher Preparation...........................25

Preparation of Bilingual Reading Specialists .............................................29

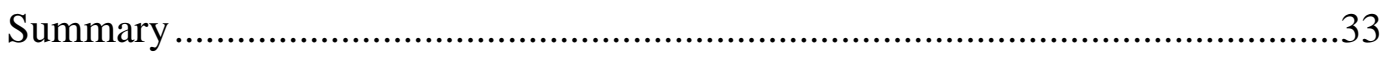


Chapter Three

Methodology

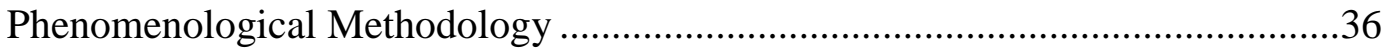

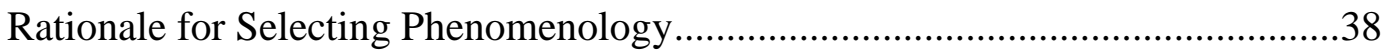

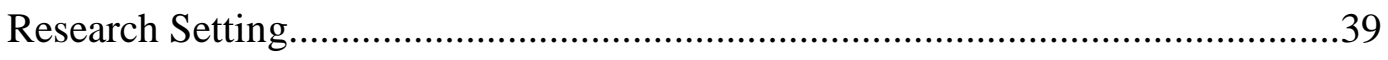

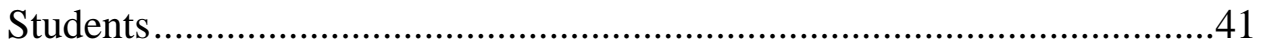

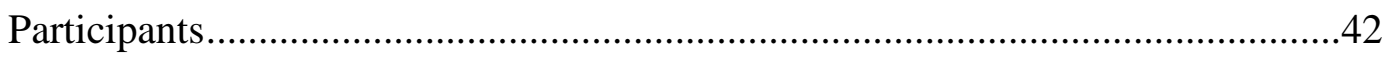

Bilingual Reading Specialists .....................................................43

Participant Selection ....................................................................44

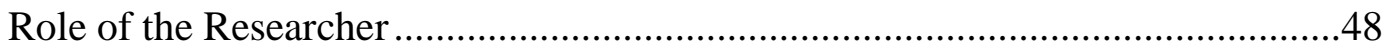

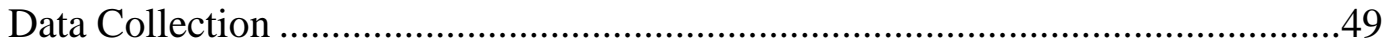

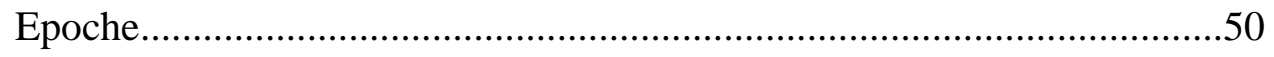

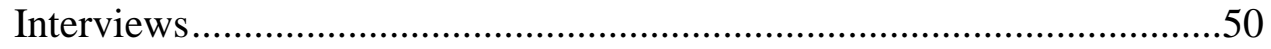

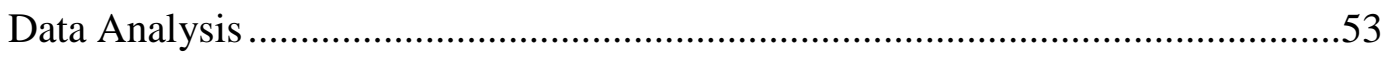

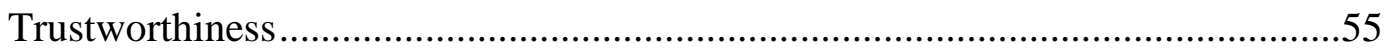

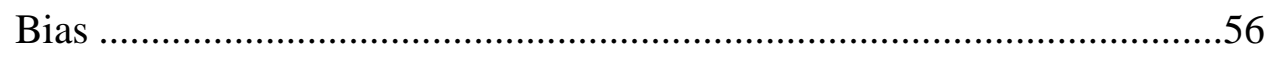

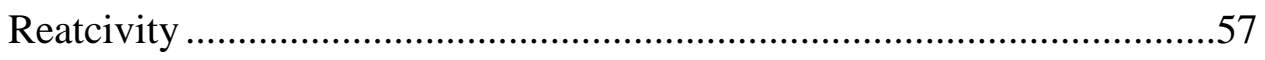

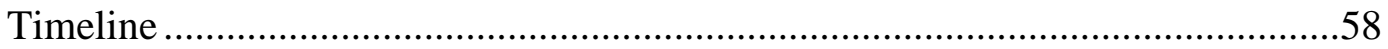

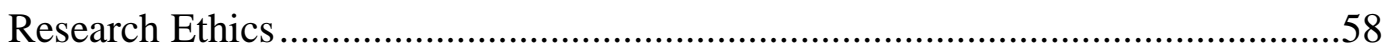

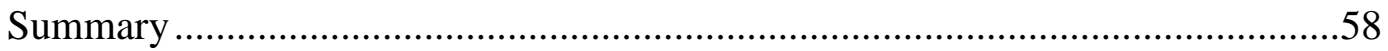

Chapter Four

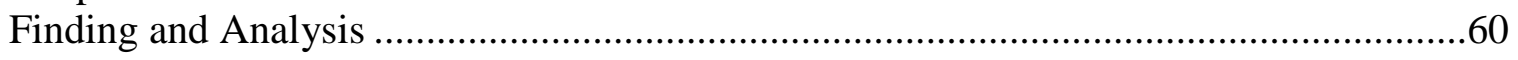

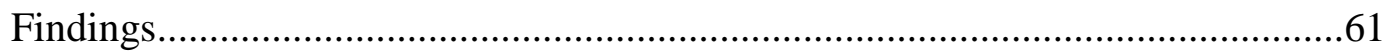


Essence of Being a Bilingual Reading Specialist ..........................................62

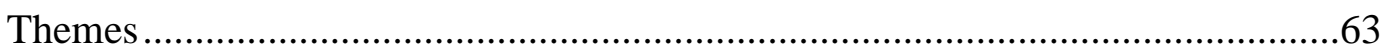

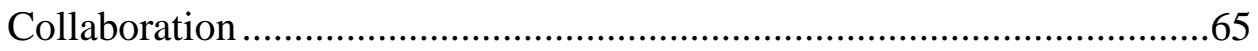

Collaboration with Teachers ........................................................66

Collaboration with Patents ........................................................... 72

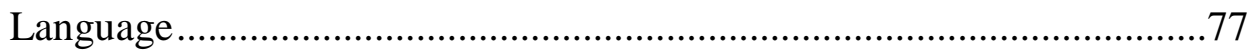

Professional Development is not Focused in Spanish ..........................79

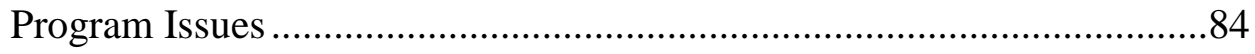

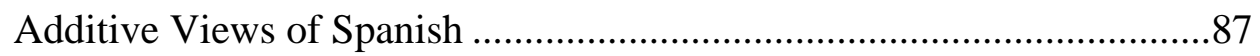

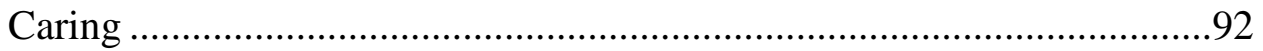

Engaging Students to Read ........................................................93

Motivating Students to Read ........................................................97

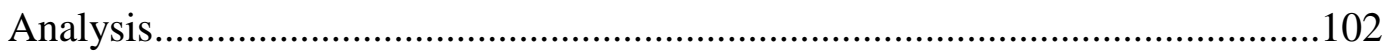

Analysis of Distinct Experiences ..................................................103

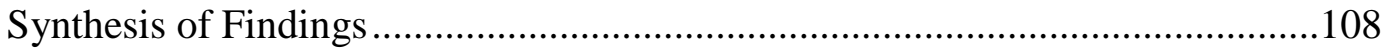

Composite Description.................................................................109

Epoche and its Role ................................................................110

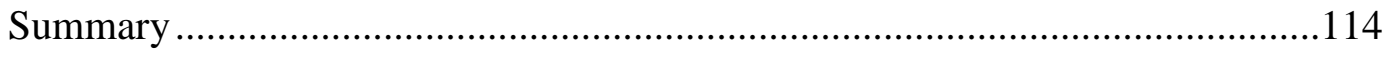

\section{Chapter Five}

Discussion, Recommendations, and Future Research .............................................115

Findings and Their Connections to the Literature ........................................116

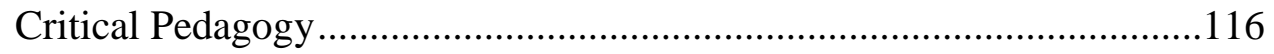

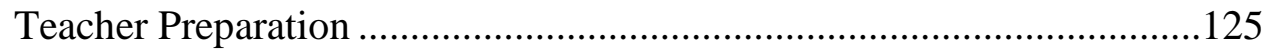


Recommendations for Stakeholders ………………....................................139

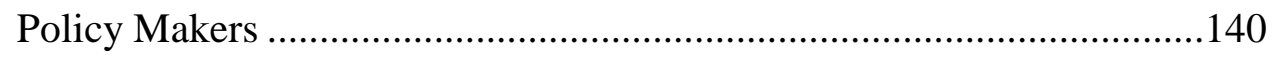

School District Administrators ..............................................................143

Teacher Preparation Ptograms …………………………………….......146

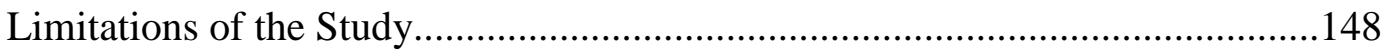

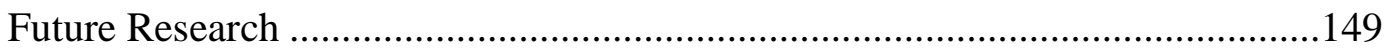

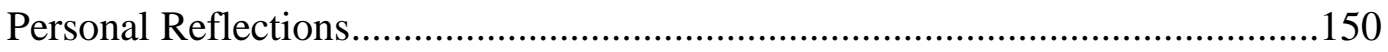

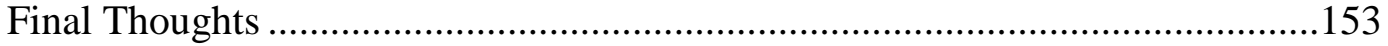

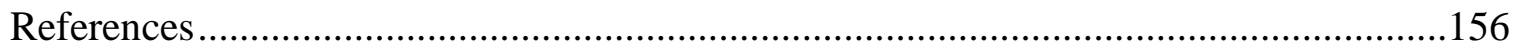

Appendices

A International Reading Association-Standard 4: Diversity .................................167

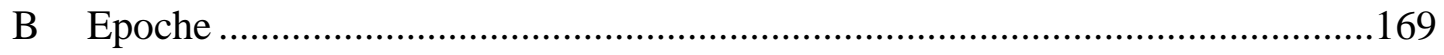

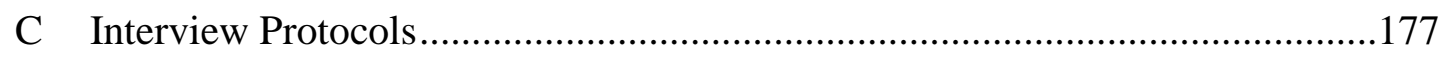

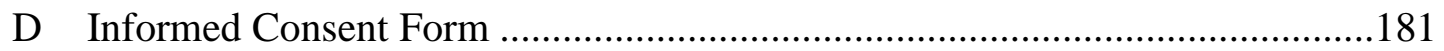


List of Tables

Table

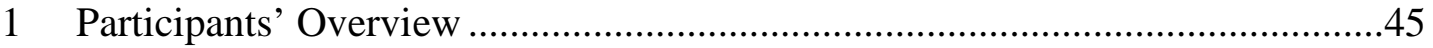

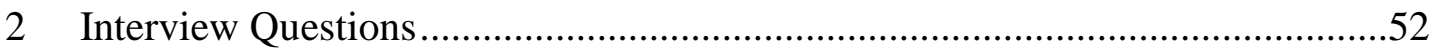

3 Frequency of Themes Represented in Significant Statements ........................102

4 Frequency of Themes and Subcategories Represented in Significant

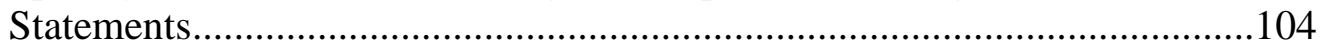

$5 \quad$ Participants and Researcher Thematic Comparison .....................................111 
List of Figures

Figure Page

1 Educar para Transformar. Dar Luz-Illuminates Transformative Ways of Thinking, Knowing, and Being ............................................................28

2 Essence of the Phenomenon of Being a Bilingual Reading Specialist...............53

3 Example of Significant Statements Organized in Excel Sheet...........................55

4 Essence of Being a Bilingual Reading Specialist.........................................62

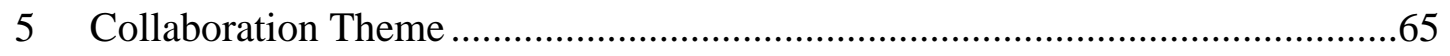

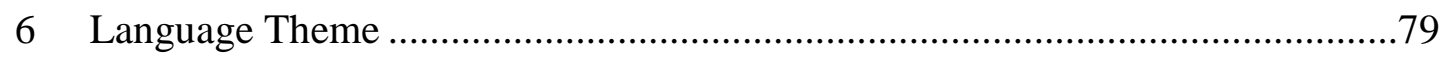

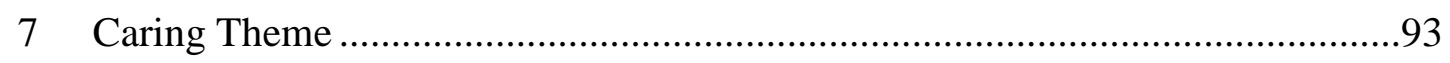

8 Critical Pedagogy View of Schools as Either a Place for Liberation or

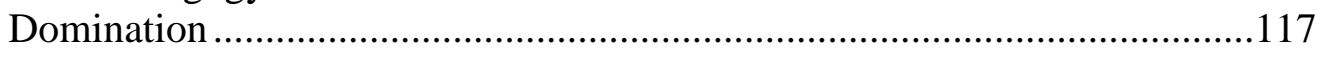

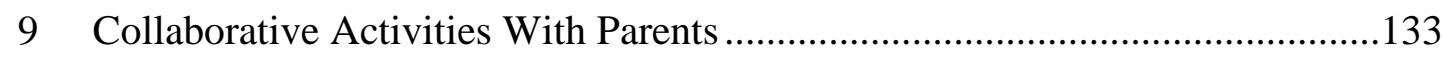




\section{CHAPTER ONE INTRODUCTION}

As the United States becomes more diverse in the $21^{\text {st }}$ century and it is impacted by global economies, "language diversity should become increasingly appreciated and bilingualism-biliteracy more widely embraced" (Fitzgerald, 2000, p. 520). Our school system should prepare world citizens, able to communicate in more than one language and able to engage and establish relationships with people from other backgrounds and countries. Speaking more than one language should be considered an asset and language viewed as a resource.

The PK-12 school population of the United States has a growing number of minority language students for whom English is an additional language that they learn once schooling starts. With such potential for bilingualism in schools, bilingual teachers should be prepared to teach biliteracy effectively, especially in the early school years when students learn to read. Unfortunately, for the most part, the students' language diversity is not being valued as an asset in the classroom and the emphasis of instruction is on acquiring English skills rather than supporting bilingualism (Macedo, Dendrinos, \& Gournari, 2003; Shannon, 1995; Wink, 2005). Consequently, the emphasis is on preparing teachers to support student English development and not biliteracy (Flores, Sheets, \& Clark, 2011).

This dissertation focuses on Spanish-English bilingual reading specialists, who are among the few in Oregon who have received biliteracy preparation offered as part of 
a reading endorsement program. They were part of a district-sponsored reading endorsement with courses delivered in English and Spanish. The courses focused on biliteracy pedagogy to ensure that teachers have the skills and credentials required to teach reading instruction in Spanish under Title I services.

In order to provide context for this study and understanding the phenomenon of biliteracy as experienced by bilingual reading specialists in Oregon, the next section provides a definition of bilingual education terms, including models of bilingual education, terms used in this dissertation to refer to bilingual students, and bilingual teachers. The definition of terms is then followed by: (a) demographic trends in school; (b) schools' approach to bilingualism; (c) personal interest in biliteracy teacher preparation; (d) reading endorsement programs with emphasis in biliteracy; and (e) a statement of the research problem and question.

\section{Definition of Terms}

Definitions of the terms used during this study to frame biliteracy and bilingual education concepts follow.

Bilingual education. Bilingual education has traditionally been designed to support English learners in acquiring English proficiency. English learners are placed in programs that vary from mainstream instruction with ESL pull-out classes, transitional bilingual programs and two-way bilingual programs. In the United States, the majority of education programs for English learners tend to assimilate English learner students in mainstream classes and emphasize proficiency in English as the main goal. Programs that do not support the development of students" first language are "subtractive" in nature 
(Valenzuela, 1999). Students most often lose their native language at the expense of acquiring English. The "additive" bilingual programs, in contrast, emphasize maintaining or developing students' native languages to foster the development of English proficiency. Bilingual programs empower English learners with the capacity to attain higher education and language competency (Lindholm-Leary, 2012; Thomas \& Collier, 2002). In recent years, Oregon has seen an increase in the number of two-way bilingual programs that provide bilingual education to ELs and native-English speakers who study side-by-side.

A short description of each type of bilingual education program according to the National Clearinghouse for English Language Acquisition (NCELA) follows. It is important to identify the program models in which bilingual teachers work with ELs and where there is a need to develop students' biliteracy skills.

Additive bilingualism. This approach to bilingual education aims to develop skills and proficiency in the students' native language as well as in English. The students' first language and culture are promoted and developed. Two-way bilingual programs and developmental bilingual education programs are part of this category.

Subtractive bilingualism. This approach to bilingual education aims at replacing the first language and culture with the second language and culture. "Instructional programs such as immersion and transitional bilingual education have subtractive bilingualism as their goal" (NCELA, 2009, p. 29).

ESL pull-out programs. English Learner students in these programs receive content instruction in English and attend an English as a second language class for one 
period of the day. This model allows schools to serve students from various linguistic and cultural backgrounds. The goal is to develop fluency in English and students do not receive instruction in their first language.

Transitional bilingual programs. These programs provide content instruction in the students' first language and then move students to instruction only in English. All students in these programs come from the same linguistic background. In early exit bilingual programs, ELs are moved to English instruction rapidly, within one to three years. In late exit transitional programs, native language instruction is maintained for at least six years.

One-way bilingual programs. These programs provide content instruction in the first language and serve students who speak the same home-language.

Two-way bilingual programs. These programs are also known as dual language programs and develop skills and proficiency in the students' native language and in English. Content classes are taught in both languages and both native English speakers and students from another language, often ELs, study side-by-side.

Bilingual students. Once students receive instruction in two languages and develop literacy in the target language of instruction or in two languages, they can be considered as bilingual students. In Oregon schools, there are two main groups of bilingual students who benefit from bilingual instruction. The former group can be placed in either One-way or Two-way bilingual programs and are usually identified as ELs upon school entry. 
English learners. English learners (ELs) are "students who are not yet proficient in English and who require instructional support in order to fully access academic content in their classes" (Ballantyne, Sanderman, \& Levy, 2008, p. 2). These students are placed in a variety of school programs and receive additional funding from the federal government to ensure their academic success after they are identified as English language learners. Their success is measured annually through State mandated tests in English. Academic success and language proficiency of ELs is measured by the norms and standards designed for mainstream students.

Emergent bilinguals. ELs are acquiring English in addition to their home language. They continue to function at home with a language other than English while at the same time are developing English proficiency to function at school. The term emergent bilingual recognizes the student's use of their home language and culture. It also recognizes that the educational needs of these students are not the same as those of monolinguals (García, Kleifgen \& Falchi, 2008).

Minority students. The term refers to Hispanic students. In this dissertation, it is used to highlight the students' sociopolitical status within the dominant language -English- and culture in the United States (Macedo et al., 2003).

Native-English speakers. Among native-English speakers in dual language programs, Freeman, Freeman, and Mercuri (2005) identified three groups: (a) nativeEnglish speakers whose parents are Anglos and come from middle-class or upper-middle class; (b) second- or third-generation Latino children who speak English upon school entry; and (c) native English speakers from other ethnic backgrounds. Parents of these 
groups are normally in support of bilingualism and see language as an asset. Students from the first group usually have families that value education and create conditions at home to support literacy development. Students in the second group come from Hispanic parents that most likely received instruction in English and while they may speak Spanish they may not be literate in this language.

Bilingual teachers. Freeman et al. (2005) classify bilingual teachers working in bilingual two-way immersion programs in subgroups based on the teachers' first language and academic preparation. Among the native-Spanish bilingual teachers, the first group of teachers speaks Spanish well and received their academic preparation in Spanish. These teachers' English proficiency level varies from developing to fluent and they are most often recent immigrants to the U.S. who grew up in a Spanish-speaking country. The second group consists of native-Spanish speakers with limited or no academic preparation in Spanish. These teachers most often grew up in the U.S. and were schooled in English. The last group is comprised of native-English teachers who have varying degrees of proficiency in Spanish, from receptive skills to college majors or minors in Spanish.

Biliteracy. At its simplest definition, biliteracy is the ability to both read and write in two languages (Escamilla, Ruiz-Figueroa, Hopewell, Butvilofsky, \& Sparrow, 2010). Pérez and Huerta (2011) defined biliteracy as "the use of or creation of text, written or oral, for thinking, reflecting, and problem-solving within a sociocultural, and bilingual context" (p. 116). They contrast the view of bilingual education as compensatory in the U.S. to a more purposeful view of biliteracy in other countries as an 
"intentional educational outcome linked to the social elite or to global commerce" (Pérez \& Huerta, 2001, p. 116). In this paper, I refer to biliteracy as the development and achievement of reading and writing in two languages, namely Spanish and English.

\section{Demographic Trends in Schools}

Demographic trends in the US show an increase in the number of minority language students who enter public education each year. Minority language students "whose first language is not English and who are in the process of learning English" (NCELA, 2009, p. 11) are considered ELs. In 1990, 1 in every 20 students in public schools in the United States was classified as an EL (Goldenberg, 2008). In 2008, one in every nine students was an EL and it was projected that in 20 years it will be one in four (Goldenberg, 2008). The majority of these students—approximately 80\%-come from Spanish-speaking families (Goldenberg, 2008). The Oregon Department of Education (ODE, 2011) reported that the percentage of ELs enrolled in Oregon schools has increased by 378\% from 1998 to 2011. In Oregon, 77\% of ELs speak Spanish. Hispanic students constitute the largest minority group, with $21 \%$ of the total K-12 student enrollment in 2011-2012 in Oregon (ODE, 2012).

ELs lag significantly behind their English peers in academic achievement in school (Caaps, Fix, Murray, Ost, Passel, \& Herwantoro, 2005; Dias-Rico \& Weed, 2010; Echevarria, Vogt, \& Short, 2010; Goldenberg, 2008). According to the 2012 ODE Statewide Annual Report Card, ELs and Hispanic students are behind their peers in reading skills in English. Hispanic students also have the largest dropout rate in the state with $23 \%$ of the total state dropouts (ODE, 2012). 
Given this growing demographic and the academic concerns that ELs-and Hispanic students in particular-have not kept pace with their peers, it is necessary to address the achievement gap with effective instruction (Diaz-Rico \& Weed, 2010; Echevarria et al., 2010; Goldenberg, 2008). Providing ELs with instruction that values their language and culture prevents students from feeling alienated and being prone to dropout school (Lindholm-Leary, 2004; Wink, 2005). The education ELs receives needs to value their culture and provide an anchor for learning while at the same time enrich the learning of all students (Gay, 2002; González, Moll, \& Amanti, 2005; McIntyre, Rosebery, \& González, 2001; Wink, 2005). Furthermore, given the linguistic and cultural diversity that Spanish-speaking students bring to their classrooms, it is important that the school curriculum capitalize on the native language of EL students. Teachers need to be prepared to address the linguistic and cultural diversity in their classrooms (Quezada \& Alfaro, 2012). Teachers with biliteracy skills are in a strong position to develop biliteracy skills in students and support them in becoming bilingual and bicultural (Flores et al., 2011; Freeman et al., 2005).

\section{Schools' Approach to Bilingualism}

Since 1974, the Supreme Court decision in Lau v. Nichols required school districts to implement the education of language minority students in a way that ensures equal access to the content delivered in English (Crawford, 1996; Mora, 2009). This meant that the responsibility of educating children fell on the school districts and they had the obligation to have a system in place to develop both English language proficiency and content mastery simultaneously and effectively. There are several ways to support 
student English language and academic development, ranging from pull-out English classes to two-way bilingual programs. While complicated and with much variety, these different programs were described under the definition of terms section. Overall, bilingual programs give students the opportunity to learn academic content in their native language while gaining competence in English (Mora, 2009). Below, I elaborate on subtractive and additive approaches to bilingual instruction in the United States.

Upon entering school, ELs receive English developmental classes and other academic support; the goal of our current school system and the No Child Left Behind Act of 2001 (NCLB) is to support English acquisition so that students move out of nonEnglish-speaker status. However, such a subtractive approach to bilingualism means that students' native languages are neglected and that an opportunity to support bilingual students in schools to become world citizens is lost (Macedo et al., 2003).

It is important to note that additive bilingual programs have been identified as the most effective way to educate ELs (Diaz-Rico \& Weed, 2010; Guerrero, 1997; Lindholm-Leary, 2012; Ramirez as cited in Cloud, Genesee, \& Hamayan, 2000; Thomas \& Collier, 2002). Bilingual education provides instruction for learners in their native language first in order to develop literacy in their native language. English is introduced by developing English oral proficiency skills and literacy skills through content classes and English language development classes. Research supports instruction and development of students' native languages to facilitate the acquisition of English language proficiency and academic content knowledge (Cloud et al., 2000; Cummins, 1991; Lindholm-Leary, 2012; Ramirez et al. as cited in Cloud et al., 2000; Shin, 2013; 
Thomas \& Collier, 2002). Students who develop literacy in their native language have an easier transition to developing literacy in a second language. They also develop cognitive academic language proficiency (CALP) in their second language faster which allows them to be successful in content classes taught in English (Cummins, 1991). EL students who develop strong literacy in their first language (L1) will do better than their peers who do not receive literacy instruction in L1 in achieving literacy in the second language, in this case English (Goldenberg, 2008).

Despite national trends of subtractive bilingualism, there are school districts in Oregon that are implementing research based practices that support bilingualism. These school districts are considering the needs of ELs in a progressive way by implementing additive bilingual programs. These programs are known as Two-Way Immersion or Dual Language programs and are effective in equipping students to become bilingual and biliterate (Cloud et al., 2000; Freeman et al., 2005; Lindholm-Leary, 2012; Thomas \& Collier, 2002). The majority of two-way immersion programs target Spanish instruction. Students develop biliteracy skills, that is, they learn to read and write in Spanish and English. Moreover, these programs benefit both ELs-minority language speakers and native-English speakers.

Therefore, there is an increasing demand for bilingual teachers in Oregon each year to teach in bilingual programs, especially at the primary grade levels. Consequently, there is a need in Oregon to effectively prepare bilingual teachers who can help Spanishspeaking students develop biliteracy skills in the early grades. Unfortunately, teacher preparation programs in Oregon are not fully preparing bilingual teachers in biliteracy 
pedagogy. Thus, there are a few school districts that are filling the void of teacher preparation in the state by providing appropriate professional development in biliteracy pedagogy.

\section{Personal Interest in Biliteracy Teacher Preparation}

As a former bilingual teacher I was fortunate to be part of a school district that in the span of eight years moved from a subtractive bilingual program to an additive bilingual program. The district now offers two-way immersion programs to minority language speakers as well as native-English speakers from K-12 grades. At the time I started teaching in the public school system, I had a master's degree in Bilingual Education and one year teaching experience in a Spanish immersion program at a private school. Because of the shortage of bilingual teachers, I was hired with a provisional license and started teaching second grade in a bilingual program. I completed an initial teaching license program and within three years I was authorized to teach Early Childhood and Elementary levels and had an ESOL/Bilingual endorsement. I was considered as a highly qualified teacher by NCLB standards. However, all the literacy pedagogy courses I took at the university during my teacher preparation program focused on literacy strategies to teach monolingual English students. This was also the case of the professional development I received during my tenure in the school district. Although I knew the basics on how to teach literacy I felt that there was more that I needed to know to improve the development of biliteracy skills in students. It did not seem that anyone around me had the answers on how to effectively teach biliteracy or the approaches that were more effective when developing Spanish literacy. 
The literacy instruction pedagogy I received during my studies and teaching in Oregon focused on research based on monolingual English populations. I was often told by the school district staff and by the people providing the professional development to translate and use these strategies in Spanish. I perceived this as either a lack of understanding of bilingual processes and instruction or as an universalist approach (Bruner, 1996) where the dominant culture establishes policies and procedures for instruction in the public school system that do understand or value the perspective of Spanish-speaking teachers in the pursuit of developing biliteracy instruction.

\section{Reading Endorsement Program With Emphasis in Biliteracy}

In 2007, a highly diverse and progressive school district partnered with a local university to provide a reading endorsement that addressed the needs of their bilingual staff. Teachers in this bilingual program had consistently expressed to administrators their need to receive instruction in how to teach literacy in Spanish. The teachers' frustrations were similar to the ones found by Escamilla (2006), where bilingual teachers expressed frustration with the lack of preparation in Spanish reading and writing pedagogy as well as their lack of Spanish academic language knowledge.

These teachers wanted to be prepared to teach biliteracy to their students. At the request of teachers, the district asked the partner university to include courses taught in Spanish that address the pedagogical issue of Spanish literacy development and biliteracy. Twenty-one teachers signed up for the endorsement program, including 17 Spanish-English bilingual teachers, one Russian-English bilingual teacher and three monolingual English speakers. The Spanish-English bilingual teachers did not want to 
take classes that presented literacy research and strategies only in English that they in turn had to adapt and translate to Spanish. They wanted specific pedagogy that supported literacy instruction in a bilingual program and would help students transfer literacy skills from Spanish to English successfully. In addition, the teachers requested that the instructors be native Spanish speakers with knowledge and practice of teaching literacy in Spanish. This was the first time in Oregon that reading endorsement courses were offered in Spanish and included a biliteracy component.

This district was not only leading the State in additive bilingual education but it was also breaking ground in teacher preparation by providing bilingual teachers with biliteracy professional development. This reading endorsement program, that included biliteracy pedagogy courses, was a significant step to advance the professional development of bilingual teachers in the State. This endorsement was an example of commitment to bilingual education with a social justice position by the school district and its partner university.

\section{Statement of Problem}

There is little research in the area of biliteracy among Spanish-English bilinguals and a need for professional development for bilingual teachers in the area of Spanish literacy for bilingual children (Beeman \& Urow, 2013; Bialystok, 2007; Escamilla, 2006; Lindholm-Leary, 2012; Flores et al., 2011). Escamilla (2006) pointed out the lack of specific research that addressed the literacy experience of bilingual students in the United States who grow up in a bilingual environment and that differs from the experience of monolingual Spanish-speaking students who grow up in Latin America or other countries 
where Spanish is the dominant language. Furthermore, Escamilla insisted on the need for research to understand the literacy development of Spanish-English bilingual students in the United States. There are recent studies about biliteracy and literacy transfer that focus on students (August \& Shanahan, 2008; August et al., 2006; Bialystok, 2007; CárdenasHagan, Carlson, \& Pollard-Durodola, 2007; Escamilla, 2006; Escamilla, Ruiz-Figueroa et al., 2010; Goldenberg et al., in press; Vaughn, Cirino, \& Linan-Thompson, 2006) but not enough studies focusing on bilingual teachers or bilingual reading specialists and their experience with biliteracy.

Although an initial examination of the reading endorsement program with courses in English and Spanish was conducted (LaForce, Cevallos, \& Torres, 2009), the study did not find out how the teachers who took these courses perceive their experiences of teaching biliteracy. The purpose of this dissertation was to study how bilingual reading specialists who received this endorsement perceive and live their experiences teaching biliteracy.

The purpose of this research is to explore the lived experiences among Oregon bilingual reading specialists. The research question is "How do bilingual reading specialists understand the phenomenon of teaching biliteracy to bilingual students?"

This study was situated within a critical pedagogy framework and aimed at exploring the lived experiences of Spanish-English bilingual reading specialists about biliteracy instruction and their work with bilingual students. The study focused on teachers who work in the bilingual school district where the reading endorsement with 
emphasis on biliteracy pedagogy courses took place. These teachers teach both nativeEnglish and native-Spanish students in One-Way or Two-Way bilingual programs.

The teachers' insights can help teacher educators to better understand the nature or essence of biliteracy in order to better understand what this particular experience is for bilingual reading specialists. Teacher educators could then evaluate their current practices and revise their curriculum to better serve the needs of bilingual teachers. In 2013, a group of school districts and universities partnered to form the Oregon Dual Language Teacher Preparation and Licensing Working Group, where they identified specific competencies required for teachers in dual language and bilingual settings and create a dual language specialty at the district and state level (G. Garcia, personal communication, April 17, 2013). These competencies were adopted by the Teacher Standards and Practices Commission (TSPC) on March 6, 2014. This study gives voice to bilingual reading specialists and informs school districts, universities and state policy makers about the experiences of those practicing in the field. Moreover, teacher educators, school districts and state policy makers can identify and put forward an agenda for change in the way bilingual teachers and reading specialists are being prepared in regards to biliteracy pedagogy.

\section{Summary}

Bilingual education has been proven to be an enriching experience for both minority language students and native-English speakers (Beeman \& Urow, 2013; Cloud et al., 2000; Lindholm-Leary, 2012; Thomas \& Collier, 2002). Especially in the context of two-way immersion programs, Spanish-speakers assume a positive attitude toward 
their language and culture as it is validated within their schooling and interactions with native-English peers (Freeman et al., 2005; Lindholm-Leary, 2004). It is important that bilingual teachers are effectively prepared to teach bilingual students and support biliteracy development in this educational context. This could not only help close the achievement gap that currently exists among Hispanic and Anglo students (LindholmLeary, 2012) but it would also help foster positive attitudes toward minority-language speakers and cultures (Freeman et al., 2005). As more two-way bilingual programs in Oregon require effective bilingual teachers who can help students develop biliteracy, researching the lived experiences of Spanish-English bilingual reading specialists who work with bilingual populations would be a useful piece to understand how to effectively design bilingual teacher preparation programs to best serve bilingual students. 


\section{CHAPTER TWO}

\section{LITERATURE REVIEW}

The United States has experienced a shortage of bilingual teachers for more than 20 years (Flores et al., 2011; Freeman et al., 2005). This shortage was exacerbated by the federal and state requirements for teacher licensing, teacher attrition and low number of bilingual candidates entering teaching preparation programs. Olivos and Sarmiento (2006) reported a critical need for bilingual qualified teachers who can "promote student competency at high academic levels in two languages" (p. 71). There is also a need for specific preparation for bilingual teachers to effectively teach biliteracy (Beeman \& Urow, 2013; Escamilla, 2006; Flores et al., 2011; Lindholm-Leary, 2012; Pérez \& Huerta, 2011). The Teachers Standards and Practices Commission (TSPC) in Oregon adopted dual language competencies for teachers in Two-way Immersion programs. School districts and universities can devise immediate responses to the gap in teacher preparation that addresses biliteracy. It is important to bring the voice of bilingual reading specialists to the conversation and planning of teacher preparation while understanding the national trends that have created this gap due to subtractive bilingualism policies.

The following literature review focused on four fields of research regarding the preparation of bilingual teachers who are prepared to teach biliteracy: (a) education of minority populations from a critical pedagogy perspective; (b) how subtractive bilingualism frames teacher preparation in Oregon; (c) critical pedagogy approach to bilingual teacher preparation; and (d) preparation of bilingual reading specialists. With 
few studies focusing on preparing bilingual reading specialists, the literature review in this area is reflective of that gap.

\section{Education of Minority Populations From a Critical Pedagogy Perspective}

According to Giroux (2002), critical theory is both a school of thought and a process of critique. The former is a legacy from a philosophy articulated by the school of Frankfurt that examined emerging capitalism along with the forms of domination that developed with it. The latter, provides the basis for a theory of radical pedagogy that "refers to the nature of SELF CONSCIOUS CRITIQUE and to the need to develop a discourse of social transformation" (p. 27, emphasis on the original). This radical pedagogy is also known as critical pedagogy (Freire \& Macedo, 2002). According to McLaren (2002), critical educators "recognize the problems of society as more than simply isolated events of individuals of deficiencies in the societal structure" (p. 69). Critical educators look at history in order to understand contextual influences for present circumstances; the present is analyzed for its potential to change current structures of domination. Critical educators aim at creating conditions for a society based on nonexploitative relations and social justice (McLaren, 2002; Wink, 2005). In analyzing power relations and ways in which the dominant culture maintains current societal structures, McLaren described hegemony as the use of consensual social practices and structures. He said that

Hegemony is not a process of active domination as much as an active structuring of the culture and experiences of the subordinate class by the dominant class. The dominant culture is able to "frame" the ways in which subordinate groups live and respond to their own cultural system and lived experiences. (p. 77) 
The current education policies in the United States emphasize the hegemony of English as a language of power and consequently influence teaching preparation programs. Macedo et al. (2003) stated that "in view of lack of criticism in most ESL teacher training programs, due to their emphasis on the technical acquisition of English, most ESL teachers ... fall prey to a paternalistic zeal to save their students from 'nonEnglish-speaker' status" (p. 10). The emphasis is on assimilation and subtractive bilingualism practices. Freire saw education helping individuals to "understand themselves and their world with a view toward transforming it" (Oldenski, 1997, p. 64). However, he recognized the limitation of education as a system that is controlled by the groups in power and perpetuates the current societal structure (Shor \& Freire, 1987). Although the United States is home to the fourth largest Latino population in the worldafter Mexico, Spain and Colombia (Flores et al., 2011), minority interests are not considered as an additive value in society and are therefore ignored. Language use and policies reflect the societal structures of the groups in power (Macedo, 2000; Macedo et al., 2003; Shannon, 1995) and thus place Spanish as a lower status language in the United States.

Despite the increasing number of language minority students who enter public school, minority populations do not hold a power status in society (Crawford, 2001, 2004a; Macedo, 2000; Macedo et al., 2003; Wink, 2005). Speaking a language other than English upon school entrance is perceived as a deficit (Bruner, 1996) that needs to be overcome through English instruction and assimilation. Current educational policies are subtractive in nature when they support English instruction at the expense of native 
language development. In 2001, the former Office of Bilingual and Minority Language Education changed its name to Office of English Language Acquisition, Language Enhancement, and Academic Achievement for Limited English Proficiency Students (OELA), reflecting the emphasis in English acquisition rather than on bilingualism. ELs' academic progress is measured in English, regardless of their English proficiency. ELs need to demonstrate academic competency, by taking content exams, in a language that they haven't fully mastered. Failure of students is perceived as confirmation of the deficit hypothesis and aggravates the situation of ELs in schools (Abedi, 2004; Crawford, 2004b; Wright, 2006).

From a critical pedagogy perspective, schools are seen as sites of both domination and liberation (Freire, 2000; McLaren, 2002). As a site for liberation, schools can help the dominated class to liberate itself from current oppressive situations as they aim for the possibilities of transforming their present conditions (Freire \& Macedo, 2002). Such schools will frame the education of ELs to create the conditions for social justice, equality and empowerment (Wink, 2005). This transformative or liberatory education of language minorities includes the recognition and value of the students' native languages as assets (Flores et al., 2011; Macedo, 2000). It would also empower minority students by respecting and dignifying their own histories and cultural traditions (Macedo et al., 2003).

Additive bilingual programs can facilitate this process; these programs aim to develop skills and proficiency in the students' native language as well as in English. The students' first languages and cultures are promoted and developed (Freeman et al., 2005; 
Lindholm-Leary, 2004; NCELA, 2009). In the case of two-way bilingual programs, ELs native languages are seen as valuable as they serve as linguistic models for nativeEnglish speakers who learn the non-English language (Cloud et al., 2000; Diaz-Rico \& Weed, 2010; Freeman et al., 2005).

\section{Subtractive Bilingualism Frames Teacher Preparation in Oregon}

In the United States, the majority of education programs for ELs assimilate EL students in mainstream classes and emphasize proficiency in English as the main goal (Fitzgerald, 2000). In fact, "two-thirds of all bilingual students (BLs) enrolled in Englishonly classes are quickly mainstreamed into traditional content classes" (Hopstock \& Stephenson, as cited in Rios \& Van Olpen, 2011, p. 164). Bilingual students are perceived as lacking English and bilingual education is mainly seen as compensatory. Few Latino bilinguals achieve biliteracy (Pérez \& Huerta, 2011). Unfortunately, in subtractive programs, ELs lose their native language at the expense of acquiring English.

It is within this national context that the preparation of bilingual teachers in Oregon is framed. TSPC policies influence the requirements and curricula set by teacher preparation programs. Teacher preparation is currently geared to supporting the development of English in transitional bilingual programs rather than developing biliteracy. Rios and Van Olphen (2011) posited that teacher preparation for ESL endorsed teachers "must assure that candidates place high value on bilingual students' primary language development" (p. 165).

While other states, such as Colorado or California, offer biliteracy pedagogy courses and Texas has a pedagogy exam for bilingual teachers (Mercuri \& Rodriguez, 
2013), the only distinction that Oregon makes between an English for Speakers of Other Languages (ESOL) endorsement and a bilingual endorsement is documented Spanish language proficiency (TSPC, n.d.). The ESOL/Bilingual requirements were put into place in 1999 and the only revisions made so far required teachers to complete an academic program to obtain an ESOL endorsement whereas before a competency exam was sufficient (TSPC, 2009). The educational context has changed dramatically and TSPC requirements are not enough to ensure that teachers are effectively prepared to teach biliteracy. Darling-Hammond and Bransford (2005) asserted that effective teachers are crucial contributors to student learning. Teachers not only need to be prepared to teach diverse students but to also address the increasing demands of complexity in curriculum and skills necessary to succeed in our changing society. Teacher preparation programs aim to prepare teachers to effectively work with a diverse body of students, providing appropriate and differentiated instruction (Bartolomé, 2000; Darling-Hammond, 2006; Nieto, 2000b). Quezada and Alfaro (2012) suggested that future teachers need to be prepared to address the linguistic and cultural diversity in their classrooms. Teachers need to have both subject matter and pedagogical preparation.

In a study conducted by Escamilla (2006), bilingual teachers expressed frustration with the lack of training in Spanish reading and writing pedagogy, and their lack of Spanish academic language knowledge. Escamilla pointed out teachers' lack of understanding on how to instruct biliteracy to Spanish-English bilingual students. There is a reliance on using literacy, assessment strategies and methods researched in monolingual English-speaking populations. These same methods are perceived as "good 
teaching" and applied to teaching Spanish literacy to Spanish-English bilingual students in bilingual programs in the United States. This practice derives from the assumption that reading in a second language is similar to reading in a first language (Escamilla, 2006; Fitzgerald, 2000). Although learning to read a second language has some similarities to reading in the first language, the process requires an additional set of skills and strategies (Pérez \& Huerta, 2011).

TSPC established the ESOL/Bilingual endorsement in Oregon in 1996, which became effective in 1999, in response to the needs of school districts that had bilingual programs in place. The ESOL/Bilingual endorsement was intended to support the acquisition of English by ELs in transitional bilingual programs (TSPC personal communication, January 2011). In this sense, the endorsement followed national trends in which bilingual programs, specifically early-transition programs, are intended to mainstream and assimilate students into the educational system in English (BernalEnríquez in Guerrero \& Guerrero, 2009).

Having the requirements for the ESOL/Bilingual endorsement in Oregon constitutes an important step in securing qualified teachers who are competent in the target language. Fifteen years ago, only $10 \%$ of teachers serving ELs were certified in bilingual education (August \& Hakuta in Guerrero, 1997). However, as Guerrero (1997; Guerrero \& Guerrero, 2009) pointed out, bilingual teachers need to have sufficient academic language proficiency in Spanish to educate students in content areas and promote high levels of academic Spanish proficiency. Besides language competency, 
biliteracy skill development for teachers is also an important step in preparing qualified teachers (Beeman \& Urow, 2013; Blum Martinez \& Baker, 2010; Flores et al., 2011).

In addition to academic language proficiency in Spanish, specific knowledge in biliteracy pedagogy and transfer skills from Spanish to English literacy are also important to effectively teach literacy in students' native language that will better prepare them to acquire English literacy skills (Bialystok, 2007; Escamilla, 2006; Escamilla, RuizFigueroa et al., 2010). Unfortunately, there are no current requirements listed by TSPC for this specific content knowledge. The requirements are only listed for teaching English literacy to ELs as part of the ESOL endorsement competencies.

Teacher preparation programs also follow standards and recommendations by national certifying bodies such as the National Council for Accreditation of Teacher Education (NCATE) and the Interstate Teacher Assessment and Support Consortium (InTASC) which also emphasizes English instruction rather than bilingual education. NCATE and InTASC standards address the need for teachers and teacher candidates to teach diverse students and to address ELs' academic and linguistic needs. InTASC (Council of Chief State School Officers, 2011) has specific standards about understanding language development and scaffolding teaching to the student's language proficiency. InTASC standards also highlight the need to incorporate student culture into the curriculum to support learning.

InTASC and NCATE descriptors for teacher preparation programs emphasize the importance of culturally competent teachers that can meet the needs of the increasing number of ELs that enroll in PK-12 schools. However, the emphasis of knowledge, skills 
and dispositions required is for English instruction only. InTASC and NCATE do not explicitly address the needs of biliteracy knowledge and skills to support bilingual instruction. Thus, the policies and requirements currently in place in Oregon influence the curriculum that teacher preparation programs put in place when preparing bilingual teachers. Currently, the emphasis of teacher preparation programs in Oregon is on covering important concepts related to English instruction for ELs such as cultural proficiency, second language development and sheltered instruction. Although these concepts are essential for bilingual teachers, there is no mention or coverage of biliteracy pedagogy per se (TSPC, n.d.). The lack of specific requirements from TSPC regarding biliteracy pedagogy courses in bilingual teacher preparation programs leaves a gap in the knowledge and skills of bilingual teachers who do not receive these courses as part of their professional preparation program at the University (Blum Martinez, \& Baker, 2010).

\section{Critical Pedagogy Approach to Bilingual Teacher Preparation}

Macedo (2000) argued that the English hegemony prevalent in the United States places minority languages, and thus Spanish, in a subordinate role. This reality is perceived in political, economic, social, cultural and educational areas. Macedo defended bilingual education and the use of minority languages as a democratic practice that provides minorities a voice toward cultural identity in a pluralistic society. Macedo pointed out the dangers of an education that does not value the native languages of minority groups. He posited that a critical pedagogy approach to education not only questions oppressive educational practices, but also presents alternatives that value the native languages of minority groups, in this case Spanish. This approach to bilingual 
education cannot be limited to pedagogical techniques without taking into account the historical, social and economic context in which minority students are immersed (DíazSoto, 2011; Macedo, 2000). For McLaren (2002), it was important to "understand who has power and how it is reproduced and manifested in the social relations that link schooling to the wider social order" (p. 74). Díaz-Soto (2011) emphasized how critical pedagogy makes educators aware of issues of power and the constant decisions they make concerning social justice issues. Moreover, Díaz-Soto (2011) stated that:

One goal as liberatory and emancipatory bilingual/bicultural educators is to reach bilingual learners (BLs) and their families so that a basic premise of work in schools engages BLs in "reading the word and reading the world" (Freire, 1985). This work becomes critical bilingual/bicultural pedagogy. A critical bilingual/bicultural pedagogy ensures home language maintenance, soundlanguage learning, biliteracy and biculturalism. (p. 240)

Alvarez (2010) encouraged university faculty to become more socially just by informing their teaching in social justice pedagogy. She defines social justice pedagogy as pedagogy that is "aware of its positionality within the power structures of academic institutions and makes this positionality transparent and thus open to inquiry and change" (p. ix). Thus, in examining their positionality toward preparing teachers to work with minority populations, teacher preparation programs need to ask themselves what their role is in assuring that teacher candidates are prepared to meet the needs of bilingual students.

Flores et al. (2011) pointed out the responsibility of teacher preparation programs to respond to the increasing demand of bilingual teachers. They proposed a model rooted in critical pedagogy that takes into account the sociocultural perspective of learning and the political context in which bilingual education is situated. They started by questioning 
the differences in power relations that language minorities experience in the United States. As a response to this inequity, they proposed a shift in the conceptualization of teacher preparation programs framed in social justice goals. They began by referring to ELs as Bilinguals to capitalize the use of two languages as an asset. They also propose a teacher preparation model that supports bilingual programs and its emphasis in maintaining or developing biliteracy.

The model that Flores et al. (2011) proposed in the book Teacher Preparation for Bilingual Student Population follows a critical pedagogy approach. Teacher preparation programs are invited to go beyond preparing teacher candidates with the skills and knowledge suggested by NCATE and InTASC standards. They are asked to think critically about their own programs and take steps to implement a program that encompasses three dimensions. These dimensions aim to strengthen the role programs have in taking action "against oppression, within the context of a liberatory educational model" (Díaz-Soto, 2011, p. 239). Figure 1 includes the components of each dimension. In this model, faculty would prepare candidates to think critically, using a sociocultural learning model to teach, and providing opportunities for candidates to examine sociopolitical and legal influences of schooling in the education of bilingual students. The purpose is that in addition for teacher candidates to be effectively prepared to teach biliteracy and enhance bilingual students' cognitive and language skills, they also need to become advocates and agents of change. 


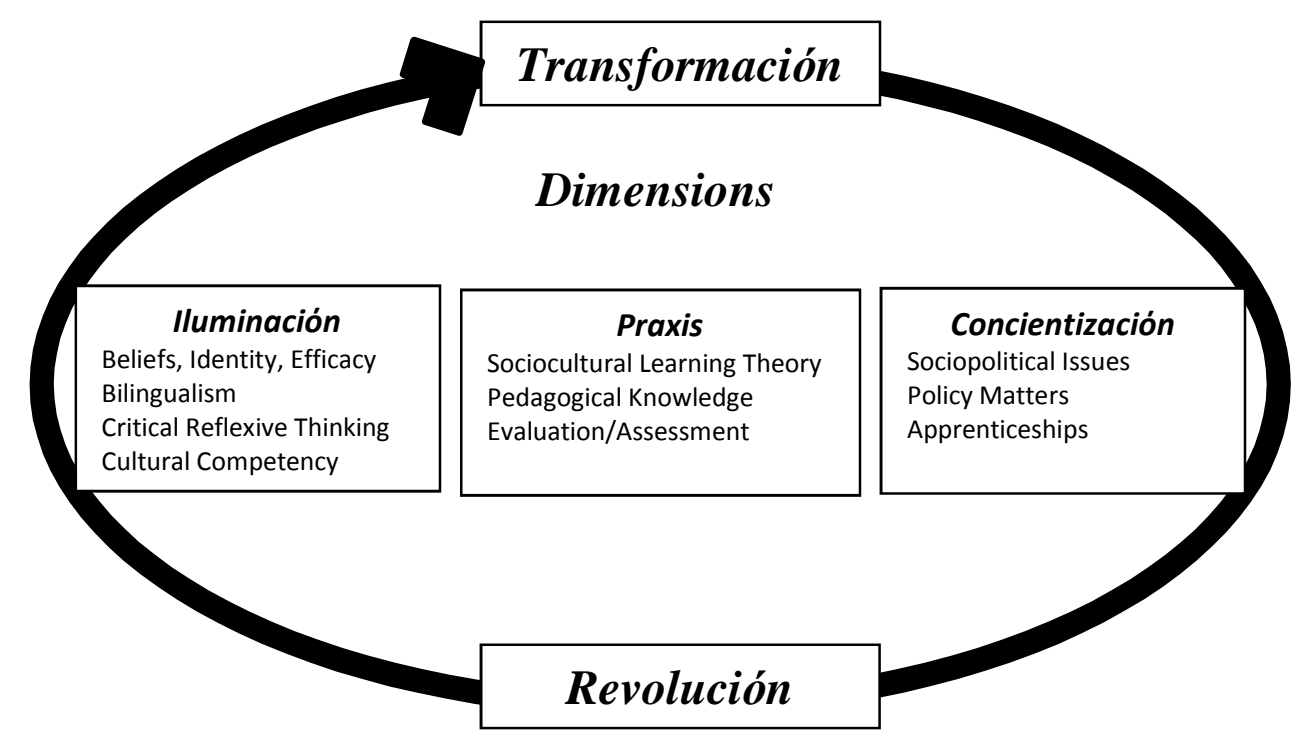

Figure 1. Educar para transformar. Dar luz-illuminates Transformative ways of thinking, knowing, and being. From Teacher Preparation for Bilingual Student Populations: Educar Para Transformar by Flores, Sheets, and Clark (2011, p. 15).

Other areas Flores et al. (2011) examined to effectively prepare bilingual teachers are: bilingual teacher identity, cultural competence, Spanish academic development, pedagogical knowledge to teach different subject areas, assessment of language and content for bilingual students, working with diverse students, parent communication, and legal policies that effect bilingual students. Special attention is placed in developing students' biliteracy and supporting maintenance or additive bilingualism. Also, teacher preparation programs are urged to address the use of academic Spanish as part of the biliteracy development for candidates (Guerrero, 1997; Guerrero \& Guerrero, 2009). Bilingual teachers need to have high levels of academic Spanish, yet there are few opportunities for them to use Spanish academically in the current teacher preparation context (Guerrero \& Valadez, 2011; Olivos \& Sarmiento, 2006). 


\section{Preparation of Bilingual Reading Specialists}

The Standards for Reading Professionals-Revised in 2010 by the International Reading Association (IRA) highlight the role of the reading specialist as teacher leader and expert teacher (Kern, 2011). Reading specialists need to be prepared to work with struggling readers and also support classroom teachers through coaching, either formally or informally (Kern, 2011).

The IRA added a diversity standard (Appendix A) to prepare teachers to work with students from diverse backgrounds, including language minority students who are considered ELs. This standard states that "candidates create and engage their students in literacy practices that develop awareness, understanding, respect, and a valuing of differences in our society" (IRA, 2010, Diversity section, para. 1). Diversity is presented as a source of strength for society. The standard values different forms of diversity; encourages teachers to "use literacy curriculum and instructional practices that positively impact students; and develops and implements strategies to advocate for equity" (Kern, 2011, p. 71).

Although, the diversity standard recognizes the need for curriculum and instruction to be appropriately adapted to meet the needs of ELs, there is no explicit mention of support in the student's native language or biliteracy. The closest position regarding literacy in the student's first language came from Vogt (IRA 2010), the subcommittee on language diversity chair, when she pointed out that being an EL does not automatically equate to being a struggling reader:

... it is incorrect to group English learners with struggling readers. Some English learners are struggling readers, in both their first and second language. Other 
English learners are very competent readers in their first language, but they struggle to read in English because of their particular level of English proficiency. (Issues section, p. 12)

IRA (n.d.) pointed out the growth in attention to reading that colleges and universities are placing now when preparing teachers. This has been in part fueled by the increasing research on acquisition of reading skills and effective teaching practices. In a study conducted by Maloch et al. (2013), first-year teachers feel better prepared to teach reading upon graduation when they are able to make instructional decisions based on context, content and student needs.

Even though the findings from Maloch et al. (2013) are encouraging, there is a lack of teacher preparation in biliteracy pedagogy (Blum Martinez \& Baker, 2010; Escamilla, 2014; Escamilla, Ruiz-Figueroa et al., 2010; Flores et al., 2011). Blum Martinez and Baker (2010) pointed out the need for specific courses in teacher preparation programs that address biliteracy pedagogy,

In the area of biliteracy, several scholars have acknowledged that most bilingual teachers lack information and skills in the methodologies of teaching literacy in the native language. There is an implicit assumption that what one has learned about reading in English can be used in the other language despite differences in script, language structure, and cultural traditions. (p. 327)

There is very little research on the Spanish literacy development of Spanish bilingual students in terms of second language writing and biliteracy development (Hedgcock, 2005; Escamilla, 2006, 2014). In terms of instructional practices, bilingual teachers need to foster literacy in both languages. August et al. (2006) and Gersten and Brengelman (1994) suggested teachers explicitly teach the transfer of literacy skills from Spanish to English. Teachers need to teach literacy in both languages and facilitate the 
connections necessary for transferring literacy skills. The suggestions in the literature are broad and not specific to transferability of biliteracy skills (Hudson \& Smith, 2001). The current research of Escamilla, Hopewell et al. (2014) and Escamilla, Ruiz-Figueroa et al. (2010) with Spanish-English emergent bilingual students in the United States pointed out that simultaneously teaching literacy in both languages supports the development of biliteracy.

Teacher preparation programs need to expand the content of their curriculum to reflect this knowledge base and capitalize the knowledge of the EL's first language. Blum Martinez and Baker (2010) pointed out the need for teacher preparation programs to specifically prepare teachers to "be knowledgeable about the methodologies used in teaching native-language literacy and how these differ from those used in teaching English literacy because of differences in language structure and script" (p. 339). It is important to acknowledge linguistic differences in both languages and make connections and differences between the two languages explicit to ELs (Goldenberg, 2008).

Olivos and Sarmiento (2006) discussed how in an era of standardized testing required as part of becoming a licensed teacher, what is not included in those tests conveys a hidden message. They illustrated this point with the Reading Instruction Competence Assessment used in California. Despite the large number of Hispanic students in that state, the Reading Instruction Competence Assessment does not assess biliteracy knowledge; the use of the heritage language in reading instruction is left out even though it has been shown to be an effective instructional practice for ELs. Olivos and Sarmiento questioned whether this omission was an oversight or rather a reflection of 
the underlying English-only ideology prevalent in that state. Through critical pedagogy lenses, the lack of specific assessment of biliteracy pedagogy competence in teaching licensure exams exemplifies the English hegemony prevalent in the U.S. (Macedo, 2000). Not surprisingly, the literature on preparing bilingual reading specialists is scarce.

Articles related to biliteracy and preparation of reading specialists mainly discuss teacher perceptions (Maloch et al., 2013) and program instructional strategies to support English literacy (Risko et al., 2008). The preparation of bilingual reading specialists in biliteracy is discussed within the general preparation of bilingual teachers and points out the need for teacher preparation programs to be deliberate and purposeful in creating the necessary conditions for teachers to become knowledgeable and skilled at teaching biliteracy (Olivos \& Sarmiento, 2006; Pérez \& Huerta, 2011) and attain high levels of bilingualism and biliteracy (Guerrero \& Valadez, 2011).

More than a decade ago, Jimenez, Moll, Rodríguez-Brown, and Barrera (1999) pointed out that Latino authors were not widely included in scholarly publications. They also questioned the lack of research in Spanish literacy despite the increasing number of native-Spanish speaker students in public schools. Jimenez et al. (1999) posited that in "the mainstream literacy arena [there were] powerful gatekeepers to the various professional journals, with ethnocentric perspectives on reading/literacy learning and teaching" (p. 271) who maintained English language literacy were the only lenses to look at literacy. Unfortunately, this situation does not seem to have changed much overtime. While addressing policymakers, administrators and bilingual teachers at the English Learners Alliance Conference in Oregon, Escamilla (2014) noted that there were no 
federally funded research projects to study biliteracy despite the growing number of emerging bilinguals in the United States.

\section{Summary}

The education of language minority students in the United States is influenced by a movement toward immersion where ELs assimilate to English education, culture and norms. Critical pedagogy theorists view this movement as a continuation of oppressive forms of domination by the groups in power that devalues minority students' language (Macedo et al., 2003; McLaren, 2002; Wink, 2005). This emphasis on assimilation and subtractive bilingualism impacts not only PK-12 schools but also teacher preparation programs.

Schools are viewed as sites for domination or liberation (Freire, 2000; McLaren, 2002). Critical pedagogy educators can use schools to empower minority students and create education conditions that reflect and address social justice. From a critical pedagogy view, two-way bilingual programs value ELs and empower students by dignifying their language, history and cultural traditions. Two-way immersion programs have the potential to prepare students for a global market and to close the achievement gap between native English-speakers and English language-learning students (LindlohmLeary, 2004).

Teacher preparation programs aim at preparing teachers to effectively work with diverse students, providing effective instruction and differentiation. The emphasis, however, is on supporting students' English acquisition and not bilingual education. InTASC, NCATE and IRA have diversity standards that support effective instructional 
practices and incorporate the student's culture in the learning process but they fall short when addressing the biliteracy skills that teachers need in order to effectively prepare bilingual students. These national accreditation bodies and professional organizations shape teacher education. Research and educators that support additive bilingual education emphasize the need to effectively prepare teachers to develop students' bilingualism and biliteracy. With few studies in biliteracy and teacher preparation for bilingual reading specialists, this is an area in need of further research. 


\section{CHAPTER THREE}

\section{METHODOLOGY}

The lack of specific requirements from TSPC in Oregon regarding biliteracy pedagogy courses in bilingual teacher preparation programs leaves a gap in the knowledge and skills of bilingual teachers who do not receive these courses as part of their professional preparation program at the university level (Blum Martinez, \& Baker, 2010). The need for this essential knowledge was voiced by teachers who serve a large number of bilingual students in the Pacific Northwest. The bilingual school district mentioned in the introduction recognized and acknowledged this gap and acted proactively by providing biliteracy courses for its bilingual staff through a reading endorsement program.

The reading endorsement offered in 2007 in this school district is the only one that has included courses in English and Spanish purposefully addressing biliteracy pedagogy in the state of Oregon. The purpose of this qualitative research study was to explore in depth the lived experiences among Oregon bilingual reading specialists in relation to biliteracy. The research question was "How does a bilingual reading specialist understand the phenomenon of teaching biliteracy to bilingual students?" An exploration of the lived experiences of bilingual reading specialists who took these courses can allow teacher educators and school district personnel to better understand the phenomenon of biliteracy as lived by these teachers, thus, informing teacher educators, school districts 
and policy makers about necessary changes in teacher preparation to support biliteracy pedagogy.

According to Creswell (2007), "a phenomenological study describes the meaning for several individuals of their lived experiences of a concept or a phenomenon" (p. 57, emphasis in the original). Thus, the purpose of this study was to describe individual experiences of biliteracy pedagogy to develop a composite description of the essence of biliteracy from the teachers' experiences and perceptions. Moustakas (1994) pointed out that such phenomenological description includes not only the "what" but also "how" a phenomenon, in this case biliteracy, is experienced.

In the following section, I provide the rationale for selecting the phenomenological methodology for this study. I then explain the setting for the study, the criteria for selecting participants and the data collection.

\section{Phenomenological Methodology}

Phenomenology is a human science that studies persons and aims to uncover a specific phenomenon in order to articulate and explain its meaning and essence as we live this phenomenon in our daily lives (Van Manen, 1990). Phenomenological studies research phenomena as experienced by a group of individuals; Creswell (2007) recommends studying between 3 and 10 participants. Phenomenological design uses retrospective reflection from the individuals who have experienced this phenomenon based on the question, "what is the nature of the phenomenon as meaningfully experienced?" (Van Manen, 1990, p. 40). 
The exploration of the phenomenon starts with a reflexive re-living of situations that embodies the phenomenon and goes beyond a simple recollection of events. The study participants sharing the lived experiences must go beyond mere recall by keeping essential aspects of this experience as it was originally lived through. For Van Manen (1990), phenomenology aims at understanding both the concreteness and essential nature of lived experiences, which he refers to as the ontic and ontological character of the phenomenon, respectively. Essence, Van Manen (1990) posited, is "that what makes a thing what it is (and without which it would not be what it is); that what makes a thing what it is rather than its being or becoming something else" (p. 177).

Creswell (2007) identified phenomenology as research activities oriented toward lived experiences. Research takes place as a dynamic interplay among these activities: (a) researcher turn to a phenomenon for study; (b) researchers reflect on themes that constitute the essence of the phenomenon; (c) researchers write a description of the phenomenon; and (d) researchers make an interpretation of the phenomenon.

I chose to use phenomenology and interview participants to engage with them in a meaning-making process (Seidman, 2006) through the stories they chose to share during the interviews. Participants engaged in a dialogue where interviews were used to (a) gather experiential narrative data to better understand the human phenomenon, and (b) as a vehicle to converse with the participants about the meaning of an experience (Van Manen, 1990). Seidman (2006) suggested using open-ended questions to have the participants reconstruct the experience; the researcher then builds upon the interviewees' responses. I followed Seidman's proposed model of three-interview series where the 
interviewer and interviewee discuss the experiences and place them in context. During the first interview, the interviewer establishes the context of the participants' experiences. The second interview allows participants to elaborate on the details of their experiences. The third interview allows participants to reflect on their experiences and their meaning. Van Manen (1990) said that it is easier to stay close to the personal experience as it was lived when people talk about it. An adequate amount of stories, anecdotes and examples related to the phenomenon provide material for the researcher to unveil the essence of the phenomenon without being tempted to over-interpret or rely on personal opinions and experiences.

\section{Rationale for Selecting Phenomenology}

As stated in the literature review, teacher preparation programs need to purposefully address biliteracy pedagogy in their curriculum in order to effectively prepare bilingual teachers (Blum Martinez \& Baker, 2010; Flores et al., 2011; Escamilla, 2006). Also, with the increasing number of Latino students in the public school system and the expansion of two-way immersion programs in Oregon, there is an increasing demand for bilingual teachers in the state. This was a timely study given that last year the Oregon Dual Language Teacher Preparation and Licensing Working Group identified specific competencies required for teachers in dual language and bilingual settings and TSPC adopted these competencies for a dual language specialty at the state level in March 2014.

Furthermore, while current research studies on Spanish-English biliteracy have focused on transference of literacy skills among students (August \& Shanahan, 2008; 
August et al., 2006; Bialystok, 2007; Cárdenas-Hagan et al., 2007; Escamilla, 2006; Escamilla, Ruiz-Figueroa et al., 2010; Vaughn et al., 2006), there is very little research about bilingual teachers and biliteracy in the United States (Escamilla, 2006; Flores et al., 2011). A phenomenological study on biliteracy could help teacher educators to interpret the lived experiences of bilingual reading specialists and go beyond its pedagogic significance of situations and relations of working with children. This deep understanding of the phenomenon of biliteracy pedagogy can urge teacher educators and licensure bodies to better address the needs of bilingual teachers and reading specialists through practices and policy changes regarding the preparation of teachers to develop biliteracy pedagogy. Teacher education programs have a critical role to play in advancing the agenda for social justice and equity in our schools (Alvarez, 2010; Flores et al., 2011; Nieto, 2000a, 2000b; Macedo et al., 2003; Wink, 2005). It is the responsibility of teacher preparation programs to prepare bilingual teachers who are able to address biliteracy development and support bilingual students to meet state standards while embracing two languages and becoming bicultural. Bilingual students who are able to navigate the school system and cross linguistic and cultural borders will be better equipped to contribute to a more democratic society with their voice being heard.

\section{Research Setting}

The study took placed in a small culturally and linguistically diverse school district in the Pacific Northwest that serves approximately 5,000 students. There are four elementary schools, two middle schools and one high school. The main languages represented in this district are English, Spanish and Russian. Latino students comprise 
$78 \%$ of the district's population and the majority of these students are U.S. born. Seventy-five percent of students qualify for free or reduced lunch which qualifies the schools for Title I funds.

The district has had some form of bilingual education since the late 1960s. In 1996, the district implemented a late-exit bilingual program in two languages, Spanish and Russian, in order to serve Hispanic and Russian students who were considered English language learners. Students in grades kindergarten through 5 received instruction in their native language first and then gradually received more instruction in English as they moved to higher grades. Under the leadership of a former bilingual program director, this district moved from a transitional program to an additive model of bilingual education over the span of eight years. In 2003-2004 the district started offering a twoway bilingual program to native-English speakers who study side-by-side with ELs and develop biliteracy in English and Spanish. Bilingual programs now extend from kindergarten to grade 12 . For the purpose of this study, I limit my discussion of bilingual programs in this district to the Spanish and English offerings at the elementary level.

The bilingual programs offered in this district where teachers experience biliteracy aim to develop biliteracy competence for their students. Currently, the district offers parents three program options from which to choose when they enroll their children at the elementary level. The three different options are briefly explained below. The first is the one-way bilingual program, known as One-Way Dual language, where native-Spanish speakers receive bilingual education in an 80/20 model. This means that when students start kindergarten $80 \%$ of the instruction is in Spanish and $20 \%$ in English. 
The amount of English instruction increases every year until reaching 50\% in grades 4 and 5. Literacy is first formally introduced in Spanish.

The second option is a two-way bilingual program, known as Two-Way Dual Language, open for native-Spanish and native-English speakers. In two of the elementary schools this program follows the same $80 / 20$ model mentioned above; the difference is that these classes are comprised of students from two different native languages. In the other two elementary schools the Two-Way Dual Language program follows a 50/50 model; instruction is divided for half of the time in English and half of the time in Spanish from Kindergarten through grade 5. The dual language program is in higher demand due to availability of space, so students enter it through a lottery process. There is also a waiting list for students who were not able to start Kindergarten within the lottery system. In one of the elementary schools, this is the only option offered to nativeEnglish students.

The third option is the mainstream program with Spanish as foreign language for elementary students (FLES). Students take classes delivered only in English. Both nativeEnglish and native-Spanish students are in this program, the latter in smaller numbers. However, students in this program also receive 30 to 40 minutes of daily instruction in Spanish since one of the strategic goals of the district is that all students will achieve biliteracy.

\section{Students}

Students in this district come from a variety of socioeconomic levels. Seventyfive percent of students at the district qualify for free or reduced lunch. Among the 
native-Spanish speakers there are U.S. born students who are second and third generation as well as recent immigrants; both groups come mainly from Mexico. There is also a small percentage (12\%) of students whose first language is an indigenous language; Spanish is their second language and English their third language. The students come from families with varying degrees of education completion, including parents who have not finished high school and work in the agricultural or service related fields. These students have a variety of exposure to literacy in the home.

Among the native-English speaking students, a variety of socioeconomic levels are represented ranging from low income families to more affluent families. There is also diversity in the degree of parental education for these students. However, this group has more parents who have completed a college-level education. There are also a few families that have moved to this district in order for their children to receive bilingual education.

\section{Participants}

Oregon had 114 teachers at the elementary level that have both an ESOL/Bilingual endorsement and a Reading endorsement (Director of TSPC's Teacher Education Programs, personal communication, March 18, 2014). There was only one cohort of 17 bilingual teachers in Oregon who took the reading endorsement courses in English and Spanish, as the courses in Spanish were only offered once during the 20072008 school year. Bilingual reading specialists in this district were native-Spanish speakers-with or without academic preparation in Spanish; and native-English-speakers who learned Spanish in college. I taught in this district earlier in my teaching career and 
knew the bilingual teachers who took these courses as I had worked with them in the past.

\section{Bilingual Reading Specialists}

The bilingual teachers were native-Spanish speakers and native-English teachers. Among the teachers who completed the bilingual reading endorsement, however, the Spanish-speaking teachers were all immigrants who were educated in Spanish in their home countries. Some of these teachers were teaching in Mexico prior to coming to the United States with a teacher exchange program. Some of these teachers went through alternative teaching licensing programs because they already had education degrees in Mexico. Other teachers had earned degrees in fields other than education in their home countries and went through a teacher preparation program in Oregon once they were hired to teach in public schools with a provisional license. The native-English speaker teachers learned Spanish in college and had majors in education or pursued a master's degree in teaching. They received their teaching licenses through traditional teacher preparation programs in the United States.

Teachers who took the reading endorsement courses ranged in age from late twenties to mid-fifties and had at least six years of teaching experience. At the time the reading endorsement courses were offered, teachers had been working at the district from 1 year to 22 years. While all of the bilingual teachers had taught in bilingual classrooms, some of them had also worked as reading specialists. Reading specialists work with small reading groups of students, from K-5 grades, who receive additional reading instruction under Title I services. 


\section{Participant Selection}

I used purposeful sampling to select bilingual reading specialists to participate in this study. Out of the 17 Spanish-English bilingual teachers who took the reading endorsement with courses in English and Spanish, 10 remained in the district teaching at the elementary level. I decided to limit my sample and invite only bilingual teachers who met the following criteria:

- They held an ESOL/Bilingual endorsement,

- They held a reading endorsement, and

- They were currently working in the district in either of the following capacities:

○ Reading specialists providing Title I services.

- Classroom teachers teaching in one-way or two-way immersion programs.

○ Instructional coaches.

Out of the 10 teachers who completed the study and were teaching in the district, at the time of the study, six ESOL/Bilingual endorsed teachers also held a reading endorsement and met the criteria. I invited all six bilingual readings specialists to participate in the study; they were all female. Five bilingual reading specialists agreed to participate. However, only four completed the study. There was a balanced representation of native-Spanish and native-English bilingual reading specialists. In order to protect the participants' identities, I used pseudonyms. Table 1 shows general information for participants and is followed by a short description of each participant. 
Table 1

Participants' Overview

\begin{tabular}{|l|l|l|l|l|l|}
\hline Pseudonym & $\begin{array}{c}\text { Native } \\
\text { Language }\end{array}$ & \multicolumn{1}{|c|}{$\begin{array}{c}\text { Country of } \\
\text { Origin }\end{array}$} & \multicolumn{1}{|c|}{$\begin{array}{c}\text { \# Years } \\
\text { Teaching }\end{array}$} & $\begin{array}{l}\text { Undergraduate } \\
\text { Degree }\end{array}$ & $\begin{array}{l}\text { Teaching Licensing } \\
\text { Program }\end{array}$ \\
\hline Marie & English & United States & $\begin{array}{l}\text { Between } 15 \text { and } \\
20 \text { years }\end{array}$ & $\begin{array}{l}\text { Other than } \\
\text { education }\end{array}$ & $\begin{array}{l}\text { Fifth year teaching } \\
\text { program }\end{array}$ \\
\hline Sally & English & United States & $\begin{array}{l}\text { Between } 10 \text { and } \\
15 \text { years }\end{array}$ & Education & Undergraduate \\
\hline Diana & Spanish & Latin America & Over 30 years & Education & $\begin{array}{l}\text { Alternative pathway } \\
\text { to licensure }\end{array}$ \\
\hline Gema & Spanish & Latin America & $\begin{array}{l}\text { Between } 15 \text { and } \\
20 \text { years }\end{array}$ & $\begin{array}{l}\text { Other than } \\
\text { education }\end{array}$ & $\begin{array}{l}\text { Master's teaching } \\
\text { program }\end{array}$ \\
\hline
\end{tabular}

Marie. Marie was interested in education and wanted to become a teacher but she first studied social sciences and Spanish during her undergraduate program. She then joined a fifth year teaching program at a public university in Oregon and obtained her teaching license. She worked in a district in central Oregon for a few years. This district had some diversity but did not have a bilingual program. Marie used her Spanish skills to support students but remembered that her Hispanic students did not want to speak Spanish at school.

Marie interviewed at the district where she currently teaches and was interested in its cultural and linguistic diversity. For her, the district provided the opportunity to work with minority students using Spanish and being immersed in the Hispanic culture represented in the community. She joined the district as a reading specialist 13 years ago, 
and whereas at the time she was one of three teachers in this role, she is now the only reading specialist at her school of around 500.

Marie studied in Mexico and lived in this country as part of an exchange program. She uses Spanish on daily basis, enjoys reading literature in Spanish and shared that this language was an important part of her life.

Sally. Sally always wanted to be a teacher. She studied education and Spanish during her undergraduate program at a public university in Oregon. She was encouraged by a faculty member to use her Spanish skills in teaching and one of her student teaching experiences was in a bilingual classroom where she taught in Spanish. Sally's first teaching assignment was in an English classroom in the district where she currently teaches. She then taught in the bilingual program and has been a classroom teacher, reading specialist, and instructional coach.

Sally applied to work in this district, motivated by the bilingual program so she could teach in Spanish. She has traveled to Central America. She was an avid reader and remembered watching television in Spanish as a way to increase her oral fluency in Spanish and learn different words and expressions from Latin America.

Sally enjoys other cultures and languages and married into a Hispanic family. She is raising her daughters as bilingual and bicultural. They attend the dual language program at the district where she teaches. She is one of three instructional coaches at her school of over 500 students.

Diana. Diana studied to be a teacher in Latin America. She was a normalista, studying to become a teacher since high-school, and pursued an undergraduate degree in 
education. She also obtained a master's degree in education, with a specialty in learning disabilities. Her thesis research focused on the role parents play at facilitating learning for children with learning disabilities.

Diana taught in her home county in preschools, early childhood development centers, schools for the deaf and blind, and at a school for children with physical disabilities. When she moved to the United States, she taught at Head Start, preschools and private elementary schools. Once she was hired by a school district, she obtained her initial teaching license through an alternative pathway program at a private university.

She has taught at this school district for 14 years at the elementary level in oneway and two-way bilingual classes. She is now one of two reading specialists in her school of around 900 students.

Diana studied French and Esperanto before she learned English. She would like to pursue a doctoral degree in education but would like those studies to be in a Spanishspeaking country, perhaps Spain or Mexico.

Gema. Gema obtained her undergraduate degree in Latin America in a field other than education. She continued with her graduate studies in the same field in Spain. She then worked at a university, in the audiovisual department, designing instructional materials for high school for a national education program in her country. She also developed programs for mathematics and provided professional development to teachers on how to use those materials and programs.

When Gema moved to the United States, she worked as an instructional assistant at a migrant summer school and then at a high school. She was the only person who 
spoke Spanish at the high school and became a liaison between school and Spanishspeaking families. She also supported students who needed help in high school to earn credits toward graduation. This work motivated her to learn English faster.

Gema taught at an immersion Spanish program at a private school in Oregon and was recruited by the school district where she currently teaches. She obtained her teaching license through a graduate teaching program at a public university. She has been in the district teaching primary grades in one-way and two-way bilingual classes for the past 12 years. In all the schools where she has taught, she has started and directed traditional Mexican dance groups. She has encouraged parents, students and teachers to join the groups. This initiative has always been well received by school administrators, teachers, parents, students and the community.

\section{Role of the Researcher}

I taught in bilingual programs at the elementary level for nine years. My first year of teaching was at an immersion Spanish school with native-English and secondgeneration Spanish speakers. The rest of my time teaching elementary school, I taught in a bilingual program where native-Spanish speakers first learned to read in Spanish first and subsequently acquired literacy in English. I also helped start a two-way immersion program and worked as bilingual coordinator for two elementary schools. For this latter role, I read research on dual language instruction, modeled lessons in Spanish and acted as an instructional coach mentoring teachers.

All the literacy pedagogy courses I took at the university-during my initial teaching licenses program and ESOL/Bilingual endorsement-as well as the professional 
development I had during my teaching career in public school focused on literacy strategies to teach monolingual English students. Although I knew the basics on how to teach literacy I felt that there was more that I needed to know to better teach biliteracy. When I first started teaching biliteracy, the emphasis was on teaching literacy formally in Spanish and developing students' oral skills in English. It was assumed that students will make the transition from reading in Spanish to English naturally. Research (August \& Shanahan, 2008) later showed that some students need explicit instruction in transferring their reading skills from one language to the other and that teaching literacy simultaneously in Spanish and English (Escamilla, Ruiz-Figueroa et al., 2010) was beneficial for ELs .

I shared my personal experience with biliteracy because in phenomenological studies the researcher needs to be transparent about her personal experiences with the phenomenon under study. It was important that I had a clear "phenomenon" to study and that I be reflexive throughout the study (Creswell, 2007). In the next section, I mention that I wrote an Epoche to restrain from judgment and have a fresh approach to the experiences shared by the participants.

\section{Data Collection}

Two data sources were collected for this study: an Epoche written by the research, and a series of three interviews completed with each participant. 


\section{Epoche}

As the researcher, I wrote an Epoche (Appendix B), describing personal experiences with the phenomenon being studied-biliteracy-and answering the questions I asked to participants. In the Epoche, the researcher brackets or sets aside her experiences to have a fresh perspective and an open mind toward the phenomenon under study (Creswell, 2007). The goal was to set aside my beliefs, assumptions, understandings and preconceived ideas of the phenomenon by first making them explicit (Van Manen, 1990). This allowed me, as researcher, to be conscious about my assumptions in order to examine them and contrast them against the experiences collected from the participants.

I started my Epoche by doing a free write and a conceptual map of the experiences that I had with biliteracy. I then narrowed in on some of the ideas captured in my initial writing and explored and wrote more about my experiences with teaching biliteracy, focusing on particular situations or events. I wanted to describe and capture how I made sense of the phenomenon in concrete ways. I also answered the questions that I used during the interview protocols and analyzed my beliefs, assumptions and preconceived ideas from my own responses.

\section{Interviews}

The participant sample consisted of four bilingual reading specialists who fit the selection criteria. Data collection included three interviews with each participant to collect stories of their lived experiences with biliteracy and a brief demographic questionnaire. Each interview lasted approximately 60 minutes. I used an interview protocol to keep notes during the interview (Appendix C). I also recorded the audio of the 
interviews using a digital recorder and a computer program called Audacity. Recording the interviews in two places allowed me to have a backup copy, should one of the recordings not be clear. I transcribed the entire audio from the interviews conducted in Spanish, keeping literal statements and noting spaces where there was silence, pauses and specific intonations or nonverbal communication. I hired a professional transcriber to follow the same procedure with the interviews conducted in English. I left large margins on the page to allow space for notes and coding later on. I transcribed the audio within two days of the interview, trying to remain familiar with the data. I conducted the interviews individually at times and locations convenient for the participants; interviews took place after school hours at the participant's classroom.

The series of three interviews for each participant spanned between two to six weeks, depending on their availability. I emailed the questions to participants ahead of our scheduled meeting time. During the second and third interviews, I first incorporated member checking by asking the participants' views on the credibility of the findings and my interpretation of what they shared during the previous interview (Creswell, 2007). I brought my notes capturing what each participant shared and allowed the participant to read them. This provided an opportunity to make corrections if necessary (Van Manen, 1990). As participants read their draft, it became a starting point to share more about their lived experiences. Each interview continued by asking participants to elaborate on something that was identified as relevant from the first analysis and then proceeded with the questions identified in the interview protocol. 
Interview questions. I adapted Seidman's (2006) model of three interviews, focusing each interview in: (a) participant's life history, (b) details of their experience with the phenomenon being studied, and (c) reflections of the meaning of those experiences. Table 2 shows the interviews questions I used during the interviews. The follow-up questions varied for each interview, depending on the responses from participants as we engaged in a dialogue that explored their experiences and understanding of teaching biliteracy. I used the participants' responses to determine the next question asked rather than moving through the interview protocols without deviation.

Table 2

\section{Interview Questions}

Interview One (focused on life history):

1. Tell me about your teaching path. How did you get here, as a teacher?

2. How did you first start teaching biliteracy? Can you describe your experience when you first started teaching biliteracy? What happened?

3. What have you experienced in terms of your preparation to teaching biliteracy?

Interview Two (details of the experience with biliteracy):

1. Tell me more about the context of your experiences with biliteracy in the classroom and/or as a reading specialist.

2. Reconstruct a typical literacy period. What do you do in your classroom?

3. Describe a memorable event in teaching biliteracy.

4. Share an anecdote that exemplifies a key value or core belief about teaching bilitearcy.

5. Tell me what you do as a bilingual reading specialists.

6. Could you talk about your relationship with your students? With other teachers? With parents? With administrators?

Interview Three (reflection on the meaning of their experiences):

1. Given what you have shared in our previous conversations, how do you view teaching biliteracy in your life?

2. If time and money were not an issue, what and how would you like to further learn about biliteracy?

3. You are in front of a panel that includes principals, district administrators, people from TSPC, legislatures and professors. You are talking on behalf of bilingual reading specialists. What would you like them to know?

4. What else would you like to add regarding teaching biliteracy? 


\section{Data Analysis}

I followed Creswell's (2007) method for analysis of interview data in

phenomenological studies. Figure 2 presents Creswell's visual for the template for coding a phenomenological study (p. 170).

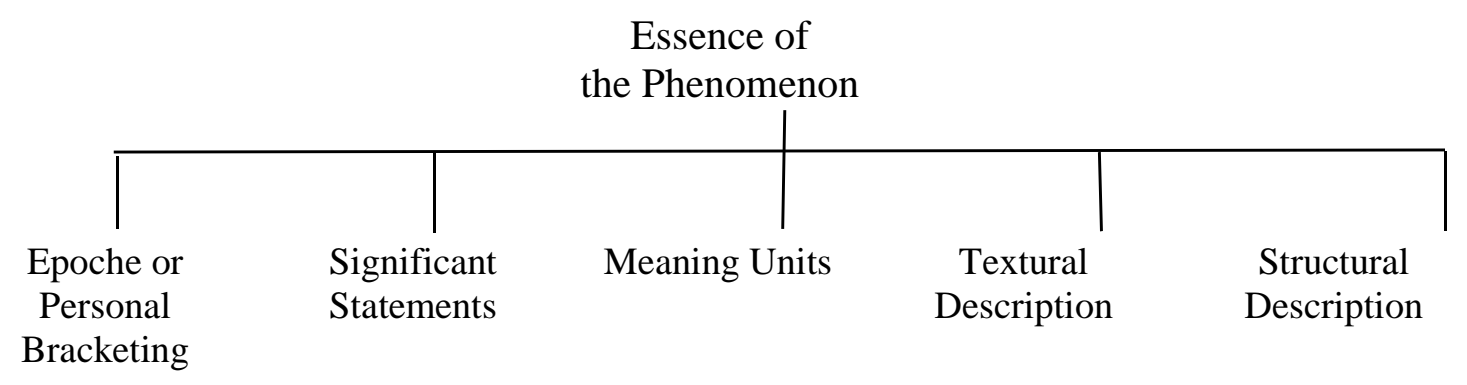

Figure 2. Essence of the phenomenon of being a bilingual reading specialist. From Qualitative Inquiry and Research Design: Choosing Among Five Approaches by John W. Creswell (2007, p. 170).

I describe below how I followed and adjusted Creswell's (2007) method for coding. There were six steps:

1. Read through the text, making margin notes and form initial codes;

2. Create a listing of significant statements for each interview, treating each statement as having equal worth;

3. Group the significant statements into meaning units or themes;

4. Write a textural description: this is a description of what the participants experienced;

5. Write a structural description: this is a description of how the experienced happened, reflecting the setting and context where the experiences took place; and

6. Write a composite description of the phenomenon being studied, based on the textural and structural descriptions. 
In the coding and analysis process, I followed Creswell's (2007) definition for identifying significant statements and followed Van Manen's (1997) suggestion of using a selective or highlighting approach to isolate thematic aspects of the phenomenon under study.

I listened to the interview transcripts several times and manually coded the transcripts on paper. I wrote notes on the margins and underlined or highlighted statements, phrases or words that seemed essential about the phenomenon being studied. I did this within a week of each interview.

After all the interviews were completed and coded, I revisited the coding once again and copied and pasted significant statements into an Excel document. These significant statements included phrases, sentences or paragraphs to which I assigned equal value. On the Excel document, I captured the participant's quote, interview and line number where the quote came from and the coding I was using. This allowed me to revisit the entire section of the interview from where quotes came in case I needed to obtain additional context for the quotes. Also, organizing the significant statements on the Excel sheet allowed me to sort them by participants, codes and themes as they emerged in the analysis. An example of the significant statements organized in Excel is shown in Figure 3.

I then grouped the significant statements into meaning units or themes. Using Excel, I was able to obtain frequency counts on the themes and subcategories identified. I also found how participants brought up the same themes in several interviews and which themes had more or less significant statements for each participant. Once I identified the 
themes, I wrote the textural and structural descriptions together and presented and discussed the similarities among participants as to how they understand the phenomenon of teaching biliteracy to bilingual students.

\begin{tabular}{|c|c|c|c|}
\hline$\frac{A}{\text { Participantv }}$ & B & c & 0 \\
\hline \multicolumn{2}{|c|}{ Participantr Quote } & coding1 & r codinge \\
\hline Engl1 & 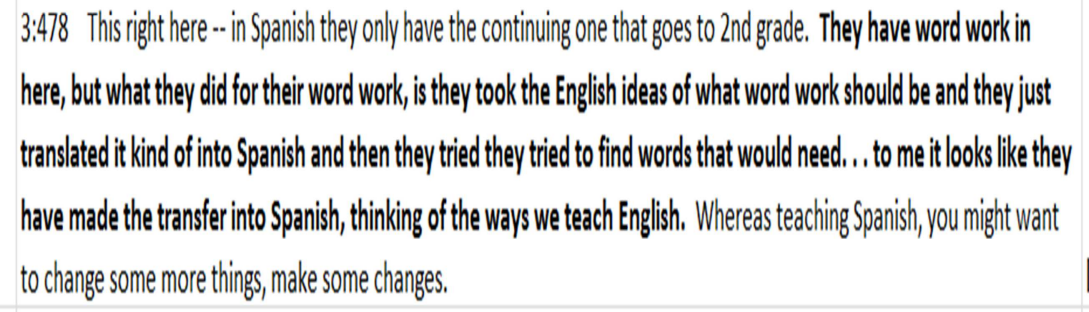 & language & materials \\
\hline SpanR1 & 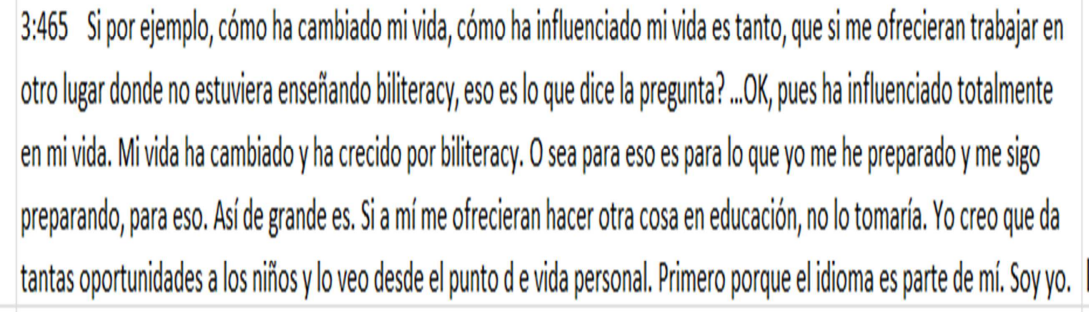 & language & supportBE \\
\hline Engl1 & 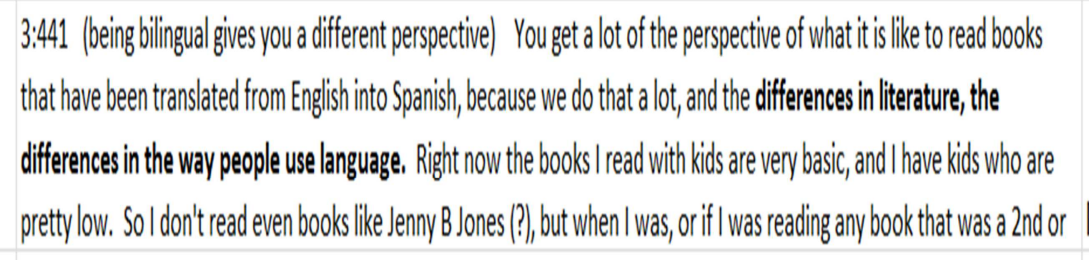 & language & materials \\
\hline SpanR1 & 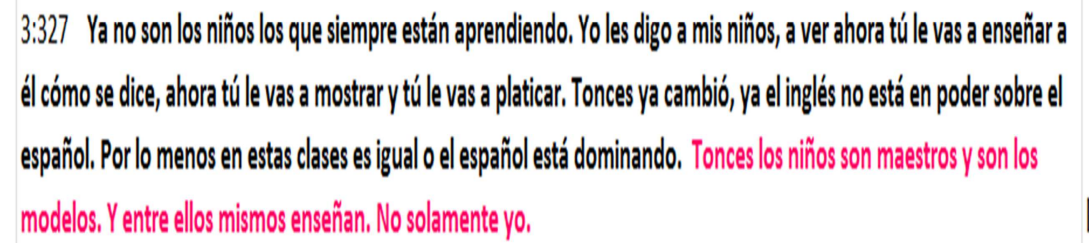 & language & value of Spanish \\
\hline
\end{tabular}

Figure 3. Example of significant statements organized in Excel sheet.

\section{Trusthworthiness}

In qualitative research, the term trustworthiness is used to convey the credibility of a study as it represents a true picture of the phenomenon being studied where the 
findings emerge from the data and not the researcher's predisposition (Lincoln \& Guba, 2000; Shenton, 2004). Maxwell (2009) emphasized how in qualitative research "the correctness or credibility of a description, conclusion, explanation, interpretation, or other sort of account" (p. 106) made the findings credible in a study. In this research, I used several strategies, listed below, to identify and address possible threats to a credible interpretation of the phenomenon being studied. I needed to ensure that the findings emerged from the data and not from my own predispositions. Maxwell (2009) cautioned researchers about two potential threats to the credibility of a study, namely bias and reactivity.

\section{Bias}

Bias is created when the researcher distorts the data and analysis with her own theory, values, or preconceptions. In order to minimize bias, I used the following.

Epoche. Before I started the interviews, I wrote an Epoche (Creswell, 2007) to bracket personal experiences and preconceived ideas and assumptions about biliteracy. I taught in bilingual programs at the elementary level for 9 years. However, in contrast to the participants of this study, I have not pursued a reading endorsement, taken classes that specifically address biliteracy, or taught in two-way immersion programs. As suggested by Van Manen (1990), I made explicit in the Epoche my understanding, beliefs, assumptions and biases about biliteracy in an attempt to bracket these beliefs.

Triangulation. I used internal consistency (Seidman, 2006) for triangulation. I used all interviews from each participant to compare the data shared by each participant 
over time to check that what is shared on the first and third interviews remains consistent. I also used the same interview protocols for all interviews for consistency.

Peer coding. I shared my initial coding for two interviews with a researcher experienced in phenomenology and a doctoral student. These colleagues acted as second coders who confirmed or questioned my interpretations and the categories or themes that I identified (Shenton, 2004).

Member checking. I took back to each participant the transcripts and interpretations from the previous interviews (Creswell, 2007) and solicited their feedback about the data, themes and conclusions that I interpreted from the previous interviews. I also sent chapter 4 to participants and requested their approval or corrections, as necessary. This provided repeated opportunities for participants to verify that the concepts, ideas and experiences they shared were accurately transcribed and interpreted or clarify and amend any misinterpretations on my part.

\section{Reactivity}

Maxwell (2005) explained reactivity as "the influence of the researcher on the setting or individuals studied" (p. 108). He added that one of the ways in which the interviewer can prevent this threat for inaccurate interpretations is by asking valueneutral or non-leading questions. In order to reduce reactivity, I made a list of possible questions and checked them with a colleague, experienced in interviewing, to ensure that I would not use non-leading questions during the interviews. 


\section{Timeline}

I collected the data and analyzed it over a period of six months. Seidman (2006) recommended keeping the interviews closer to each other so participants remain engaged in the phenomenon under study. Below is the timeline for data collection and analysis.

- Received approval from PSU Human Subjects Committee: August 2013

- Recruited participants: September-October 2013

- Selected participants: September-October 2013

- Conducted interviews: September-November 2013

- Transcribed and analyzed interviews: September-December 2013

- Conducted data analysis: October 2013-January 2014

- Completed final data analysis: February 2014

\section{Research Ethics}

I adhered to all policies and procedures of Portland State University when conducting this study in an ethical manner, including the Human Subjects Research Review Committee. Participants were asked to sign an informed consent form (see Appendix D) and I assured participants that I would protect their confidentiality by using pseudonyms. There was no coercion while recruiting participants and once they chose to participate they were free from withdrawing from the study at any time. In fact, I had one participant leave the study after completing the second interview.

\section{Summary}

The phenomenological study wanted to explore in depth the lived experiences of Oregon bilingual reading specialists in relation to biliteracy. The research question was 
"How does a bilingual reading specialist understand the phenomenon of teaching biliteracy to bilingual students?" The study was conducted in a highly diverse school district in Oregon that offers bilingual education from kindergarten to grade 12 to ELs and native-English speakers. Four English-Spanish bilingual reading specialists participated in this study; these teachers were part of a district-sponsored reading endorsement with reading courses in English and Spanish with emphasis on biliteracy.

As data collection, this study used an Epoche written by the researcher, and three sets of interviews with each participant over a 2-month period. The researcher recorded an audio of the interviews and transcribed the recordings. The researcher used several strategies to develop a credible interpretation during the data analysis, including: writing an Epoche, using internal consistency for triangulation, doing peer coding, and member checking. The study was conducted in an ethical manner and pseudonyms were used to protect the participants' confidentiality.

The critical pedagogy framework underlying this study aimed at using the knowledge gained from this study to better understand biliteracy and to inform teacher educators, school district personnel, and state policy makers about changes necessary in the state in teacher preparation to support biliteracy pedagogy. 


\section{CHAPTER FOUR}

\section{FINDINGS AND ANALYSIS}

This research study was framed in critical pedagogy. It emerged from my experience as a bilingual teacher and teacher educator in a state where bilingual education, and specifically dual language programs, are expanding due to the demographic changes and increasing number of Hispanic students in public schools. Bilingual reading specialists represent a small group of teachers in the state of Oregon, but they have a crucial role in developing biliteracy skills in students, both native-Spanish speakers and native-English speakers, who benefit from additive models of bilingual education. According to Freire (2000) and Wink (2005), educators have the ability to transform education and bring social change/justice to the school setting.

This phenomenological study explored the lived experiences of four (4) bilingual reading specialists-Diana, Gema, Marie and Sally-who teach in dual language EnglishSpanish programs in a school district in the Pacific Northwest. The research question was "How does a bilingual reading specialist understand the phenomenon of teaching biliteracy to bilingual students?" and examined individual experiences of biliteracy pedagogy through a series of three in-depth interviews with each participant. Using data analysis guidelines of Creswell (2007), this section unveils the experiences of bilingual reading specialists as agents of change through their work in biliteracy with bilingual students. 
I develop a textural and structural description of the findings through themes and present a composite description of the essence of biliteracy gathered from the experiences and perceptions of bilingual reading specialists in a district that has a large bilingual student population. In this section, the findings include excerpts from the interviews and are organized by themes as I attempt to answer the research question. The quotes also introduce the participants' voices and understandings of biliteracy. For interviews conducted in Spanish, I include the participants' words and my translation to English. The findings in this chapter are organized in the following manner:

- Findings: including textural and structural description of the participants' experiences, that unveils the essence of the phenomena through themes;

- Analysis: including the analysis of distinct experiences and composite descriptions;

- Summary: including the Epoche and its role, and the synthesis of the findings.

\section{Findings}

A phenomenological study aims at unveiling the essence of a phenomenon (Van Manen, 1990). For the bilingual reading specialists in this study, the essence was to use their knowledge of two languages and literacy strategies to develop biliteracy skills in children. Not surprisingly, language, literacy and teaching were at the heart of their experiences. Figure 4 captures what the essence of being a bilingual reading specialist is for each participant. 


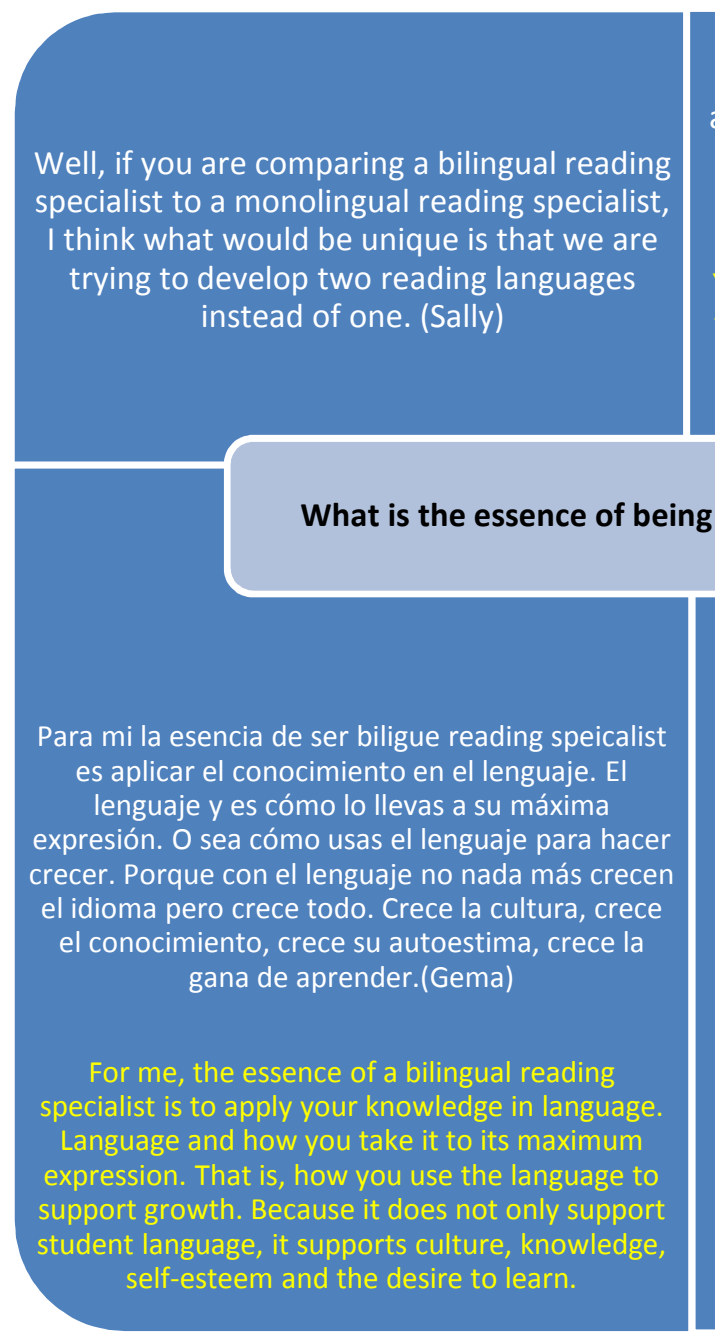

Tienes que estar constantemente con los ojos abiertos para ver la necesidad de cada niño. Porque depende de lo que tiene cada uno requiere algo distinto. Entonces hay que poderle llegar a cada uno y darle de lo que necesita. (Diana)

You have to keep your eyes open at all times to see the need of each child. Because each child requires something different. Then you have to be able to provide each child what he needs.

\section{What is the essence of being a bilingual reading specialist?}

Figure 4. Essence of being a bilingual reading specialist. What is the essence of being a bilingual reading specialist? This figure represents the participants' descriptions of what the essence is of a bilingual reading specialist.

\section{Essence of Being a Bilingual Reading Specialist}

For Marie, the essence was to help students become independent readers who develop a love for reading in two languages. She wanted to work with minority language students because she was aware of the socioeconomic disadvantages this group experienced. She felt that these students did not have strong literacy support at home; and 
that she could impact their lives by transforming students into readers. She wanted students to find a joy and purpose in reading.

For Diana, the essence of a bilingual reading specialist was captured by the ability to assess student reading behaviors and address their specific needs in the two target languages. This required keen observations and prompt responses given the short time she had to work with students during pull-out reading groups. She was committed to help students improve their reading skills and kept a detailed record of their reading progress. For her, it was crucial to individualize instruction within the reading group setting and provide opportunities for students to improve reading at home.

For Gema, the essence was captured by the use of language as a powerful tool for social transformation. She was motivated to use her native language in a dual language program and saw language and teaching as a mean to influence and support minority language students, as well as monolinguals.

For Sally, the essence was to develop reading skills in two languages. She saw biliteracy as an asset and when sharing a core value of biliteracy she discussed how her own children, who are in the dual-language program, read above grade level in English and in Spanish. She credited this accomplishment to the additive benefits of bilingualism; her children were surpassing monolingual peers in their reading skills and she felt proud of their success.

\section{Themes}

The participants were committed to developing student biliteracy skills. This motivated their work and permeated their professional and personal lives. They chose to 
work in this school district and wanted to use their bilingual skills to support student learning. The participants recognized the status of Spanish as a minority language in the United States and saw it as an asset. They acknowledged the needs of the language minority student population and were committed to their success in school. Participants wanted to develop in students a love for reading and equip them with the necessary skills to become independent and successful readers in two languages. They experienced joy and celebrated their students' successes, no matter how small they seemed. While each participant had a unique path to becoming a bilingual reading specialist, they shared similar understandings and experiences.

The essence of being a bilingual reading specialist was captured through themes as I connected threads and patterns from the interview transcripts regarding the phenomenon being studied (Van Manen, 1990). Three themes emerged as common for all participants: (a) collaboration, (b) language, and (c) caring. These themes were identified in the interview transcripts, as participants discussed their journeys to becoming bilingual reading specialists; talked about their role and how they used their knowledge to support students; and reflected on the importance of biliteracy in their professional lives.

Each of these themes is discussed in this section were the essences of the experiences that were similar among all participants. I presented the ways in which the participants articulated their understandings of the phenomenon differently. Part of these differences comes from the different roles they have as classroom teacher, reading specialist, or instructional coach. 
Collaboration. The theme of collaboration was mentioned by all participants. They viewed teaching biliteracy as a collaborative effort among teachers and also with the students' parents. The two types of collaboration in this theme are represented in Figure 5.

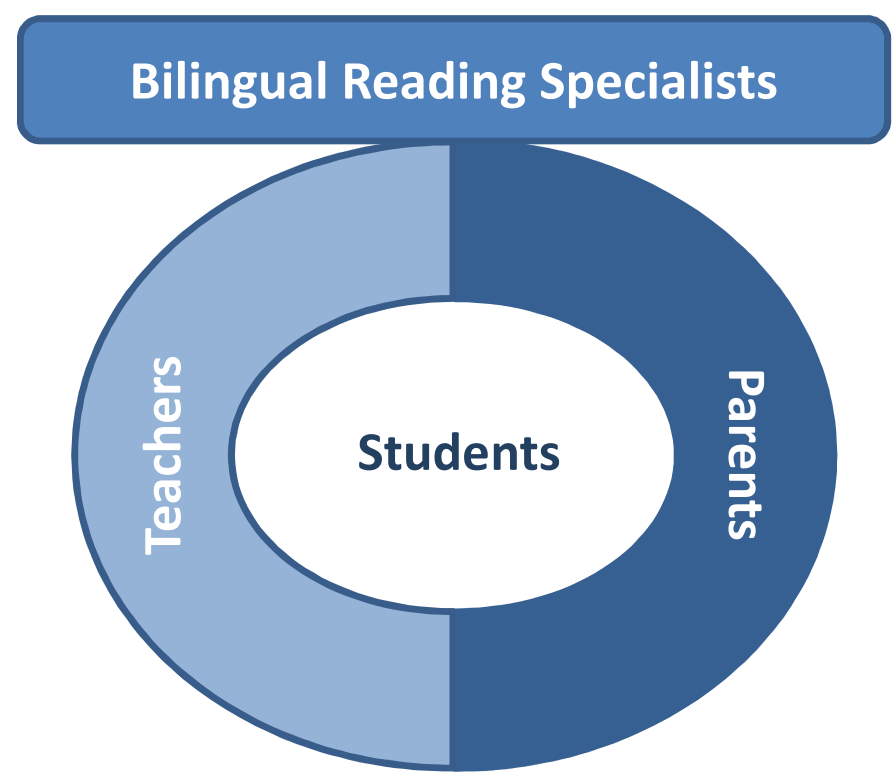

Figure 5. Collaboration theme. This figure represents the areas in which the essence of collaboration as it pertains to teaching biliteracy was discussed by participants.

Collaboration with teachers allowed bilingual reading specialists to better serve students. This started as the participants learned to teach biliteracy from other professionals, such as reading specialists or primary teachers. Then as the participants became more experienced in their role as reading specialists and through their preparation, they are now the ones supporting other teachers and refining their own practice through collaboration.

Collaboration with parents was also important. Parental support was seen as crucial in supporting student biliteracy skills development. Parents were viewed as 
partners in the learning process and their support was valued both inside and outside of school. A further elaboration on collaboration with parents is discussed later. A discussion on how collaboration with teachers happened for each participant follows.

Collaboration with teachers. Collaboration with teachers was mentioned in 27 out of 175 significant statements. It was through collaboration with teachers that the participants learned how to teach literacy in Spanish from and with their colleagues. Collaboration was also present in their daily practice when reading specialists and instructional coaches worked alongside classroom teachers and supported their work with readers who struggle. With the exception of Diana, none of the participants received courses in their initial teacher preparation programs that specifically addressed teaching literacy in Spanish. Thus, it was through collaboration with other teachers that the participants learned to teach biliteracy. Moreover, the collaborative process appeared to be at the core of how they enhanced their practice and supported others in their role as bilingual reading specialists.

Gema saw the value of collaboration as a way to learn from and with others. Despite her previous successful experience teaching at a Spanish immersion private school, Gema did not feel ready to teach in a Title I public school at first. She was aware that besides the academic demands for students, she was now facing a different school system and student population. She credited two teachers, who had been working in the district for many years, with helping her understand how to teach her bilingual students. Gema also mentioned that the reading endorsement was valuable because it provided her with an opportunity to learn alongside other teachers with whom she shared similar 
experiences. It was this collaboration that she valued most highly from the courses in Spanish:

[Referring to reading endorsement courses in Spanish] Y habían modelos y tú podías hablar en el idioma y podías intercambiar experiencias con niños que están en esta situación, que realmente son cosas que tú estás teniendo en tu salón de clases y que no sabes cómo. Podíamos hablarlas ahí y podía escuchar ejemplos. Y podía tener sugerencias de los maestros. (Interview \#2)
[Referring to reading endorsement courses in Spanish] There were models and you could talk in the language [Spanish] and exchange experiences with kids that were in this situation, which are really things you have in your classroom and don't know how to. We could talk about it there and I could listen to examples. I could get suggestions from teachers. (Interview \#2)

Furthermore, applying and sharing the knowledge and skills she gained as part of the reading endorsement were new responsibilities she embraced as a reading specialist.

For her, sharing her expertise to facilitate the literacy development of students in two languages was not only part of collaboration with other teachers in her grade level, but also reflected her professionalism:

He tenido contacto con ella [la instructora] de que qué puedo hacer en este caso. Incluso he transferido eso a Felipe [otro maestro], porque él tiene clase de estudiantes nativos y parte de la información no nomás se ha quedado conmigo, vas transfiriendo a otros lados. (Interview \#3)
I have had contact with her [the instructor] about what I can do in this case. I have even transferred this to Felipe [another teacher] because he has native students in his class and part of that information has not only stayed with me; you transfer it to others. (Interview \#3)

Gema felt responsible to impact all students in her grade level. She viewed all students in her grade level as hers since teachers in her team often switched students during the day for different projects or subjects.

In Marie's case, she felt she had a strong general literacy preparation in her initial teaching program and used that as a base to incorporate ideas from other teachers to teach 
in Spanish. Nonetheless, in her role as reading specialist she learned and borrowed ideas from other reading specialists, which in turn she applied to developing Spanish literacy for her students:

I think I had to borrow from a lot of things I saw around me . . I was learning some things from the people I worked with, because I worked with C.C., she is trained in Reading Recovery. She had some things that she was doing, which I incorporated them into Spanish. She was doing them in English but I tried to incorporate that into what I was doing with Spanish, because it was a little different because I was using syllables instead of using letters. (Interview \#1)

Marie was the only reading specialist at her school and she supported other teachers despite time constraints. Teachers were often busy in grade level meetings and professional communities. Time challenges prompted Marie to use informal opportunities, such as lunch, to talk to teachers about the students whom she served and about ideas for intervention for other students. She found that establishing relations with the classroom teachers facilitated collaboration. She bonded with teachers at the beginning of the school year and went to their classrooms to show them interventions they could use with their students. Here are two examples she shared about her work with teachers:

I've gone to work with teachers to show them how to work with kids. Some of the teachers will get kids that are pretty below grade level. They may have a child who is not reading at all, and that is where the teachers in second and third, fourth, fifth, really need a lot of help because they are not used to beginning readers. (Interview \#2)

For instance, a fourth grade teacher might have one student that is reading at a level of first grade or barely started to read yet and don't know what to do. Then I try to support them by getting them the right books to use with those kids and showing them different things that they could use, like letter charts. (Interview \#3) 
Also, she had the initiative to work with instructional assistants and showed them literacy interventions. She wanted to support the school staff so her work would have more impact, and through a collaborative effort, benefited a greater number of readers who struggle.

Diana also faced time constraints when working with teachers. She contacted teachers to work together and used her after school preparation time to attend professional learning communities and supported grade level efforts. She saw the value of forming partnerships with classroom teachers to support the students whom she served both in the classroom and during reading groups:

La idea es que me pueda hacer partner con ella [maestra] y podamos trabajar ... si logramos trabajar muy unidas y planenado con la maestra del grupo de estos niños salimos más fácilmente adelante. (interview \#2)
The idea is to become a partner with her [teacher] so we could work together ... if we get to work closely and plan with the teacher of the students in the group, we will get ahead easier. (Interview \#2)

For Diana it was easier to work with teachers with whom she had strong relationships, such as her former grade level team:

Hay unos grupos con [grado] tengo muy buen contacto porque yo fui maestra de [grado]. Nada más es decirles podemos hacer esto [un programa luego de la escuela] ... Y hay maestras de [grado] que han entendido que si ellas ponen un poco de tiempo ahorita al principio del año los niños se van. (Interview \#2)
There are some groups [grade level] with whom I have good contact because I taught that grade. All I have to do is tell them to do this [an after school program] ... And the teachers in [grade] have understood that if they put some time now at the beginning of the school year, the kids fly away. (Interview \#2)

She credited the efforts and collaboration of first grade teachers in extra literacy projects as effective and timely. For her, it was crucial that reading interventions happen in the earlier grades to avoid students falling behind in literacy in upper grades. 
Sally vividly remembered how she relied on her team as a beginner teacher and sought the advice of more experienced teachers to develop the literacy skills of a fourthgrade level Spanish-speaking newcomer with no previous schooling:

I really relied on my colleagues. I asked for a lot of help. I went down to primary people and asked them for help because I figured maybe they could help give me clues about how to help this little boy. (Interview \#1)

She learned to teach biliteracy by consulting with other teachers, trial and error, and documenting the interventions and strategies she was using. As an instructional coach, her expertise was sought out by other teachers. Sally coached teachers and worked side-by-side with them. They sat together and observed students read. They discussed how to support their students' reading behaviors and developing skills. At first she was the one that provided instructional suggestions. However, as time went by, the classroom teacher started to come up with her own ideas on how to support students and relied less on the coach's expertise. Sally saw this collaboration as a way to build capacity that benefited more students. For her, effective coaching resulted in large-scale systemic change. This year, in addition to working with individual teachers, Sally was working with a team of teachers to provide after school reading interventions to first graders who were reading below grade level. As a team, the group assessed the students' reading behaviors and identified their needs and appropriate interventions. The collaboration was ongoing and took place formally and informally. This is what she shared:

We have been targeting these specific needs that they [students] need and we talk pretty much every day, all four (4) of us, because in leaving the school we are like, Oh, my gosh, this is so exciting! These little students, they are moving! We give each other advice. I am not working with the kids who don't know how to recognize a pattern, but I talk to $M$. a lot and say, Have you tried this? She will be, Oh, no, I tried this but I'd like to tweak it a little, do you have any ideas? Yeah, 
maybe you could try this. Oh, great. We are just bouncing ideas off of each other and it is not just me giving them ideas. They give me ideas, too. (Interview \#1)

Sally saw collaboration as a powerful means to enhance instruction; teachers could think through something with thoroughness and build on each other's strengths.

All participants talked about how they brainstormed and shared ideas with other teachers. In most cases, they modified these ideas to fit their students' needs and the particulars of teaching in Spanish. For them it was advantageous to discuss with other teachers how to support readers. This not only improved their own teaching but also assisted other teachers and thus benefited more students. In their role as reading specialist or instructional coach, the participants were often consulted by other teachers regarding students and possible effective reading interventions. In some cases, they were part of a grade level professional learning community; in others they worked directly one-on-one with specific teachers or as part of the Student Intervention Team. Teachers would approach the bilingual reading specialist and ask for advice on what to do with students when they were not reading at grade level or were not making progress in reading or writing. Bilingual reading specialists provided ideas and gathered appropriate resources targeting specific reading levels or skills. Most often, these consultations were for readers who were below grade level in reading. In some cases, the reading specialist or instructional coach would plan alongside the teacher and demonstrated strategies or lessons for the teacher. As an instructional coach, Sally saw collaboration as a powerful means to enhance instruction; teachers could share ideas about interventions and build on each other's strengths. Furthermore, part of the bilingual reading specialists responsibilities were to suggest specific interventions for readers who struggled and share 
the progress made by students whom they served on the Student Intervention Team meetings.

Collaboration allowed participants to better serve the needs of their students, and to learn from and with other teachers. It also highlighted the importance of working as a community for the benefit of students. In this regard, the collaboration with parents was also often brought up during the interviews.

Collaboration with parents. Collaboration with parents was mentioned in 36 out of 177 units of meaning. All participants brought up several times the importance of working with parents to support student learning. They saw the support at home as crucial for the development of literacy skills. They sought out opportunities to communicate with parents and to directly involve them in the education process of students. Parent support and collaboration took place both at school and in the home. Collaboration with parents started with effective communication. Teachers conferred with parents during parent-teacher conferences, invited them to school-wide activities that targeted literacy, sent home books for students and parents to read together, contacted them by phone, and were available to discuss student progress and concerns.

The ways in which bilingual reading specialists interacted and collaborated with parents varied among participants. Some of the collaboration took place at established school-wide events-such as parent-teacher conferences-while others were initiated by the participants and happened one-on-one. As mentioned earlier, collaborative efforts to support literacy development also occurred at home. Below is a brief description of how each participant collaborated with parents. 
Sally valued the importance for children to have supportive families. She found that she had more time in her current role as instructional coach to talk to parents. She shared with parents how their children were making progress and discussed with them specific ways in which they could jointly support the student. This collaboration was seen as instrumental in advancing the literacy skills of the student. About working with parents, she shared:

I really try to make contact with parents when I am working with a child, just to let them know. The little girl I was telling you about, I talked to her mom the other night. It was just wonderful to sit with her and tell her how great her daughter is and how much I enjoy reading with her and giving her specific help. What my next step is [with mom], figure out what we can do together to help this kid. (Interview \#1)

Likewise, Marie sent letters home explaining to parents what they were doing in the reading groups; she also called them. She wished she had more time to talk to parents and found it difficult to meet with more parents during conferences due to the large number of students she served:

I wish that we had some better way [to talk to parents] because the conferences are so busy. I do go to the conferences for some of my kids, but it is impossible for me to go to very many. I go to some and some I talk to on the phone depending on the needs of that kid. (Interview \#1)

Marie sent books home for students to read and also for parents to read to students. This was important to her:

It is really important to have parents reading to the kids, so I've always emphasized that. I have found that has been one of the most successful things for me, to have parents that read to the kids ... I try to write the reasons why and that they [students] will be checking out books and they get to bring one home every night and you [parents] can read it to them. (Interview \#2) 
She enjoyed finding out from students that parents themselves appreciated the books and discovered authors they liked from the literature students brought home. She also worked with parents during parent nights in literacy-related activities.

Diana discussed at length several experiences regarding parent collaboration. She encouraged students to bring their parents to talk to her during conferences and made a point to discuss how students were making progress. She acknowledged that parents heard from the classroom teacher how their student was behind in reading and may be discouraged. Thus, she provided parents with activities and strategies they could use at home to support literacy skills. Diana showed me different artifacts that she sent home, for students to practice literacy skills. She also helped parents create a working station with literacy resources for students to use at home to support homework and writing. For Diana, it was important to work with the parents of readers who struggled. She viewed parents as the students' first teachers. She ensured that their work at home aligned with what she did at school, for instance helping students recognize the letter sounds and not just the letter names. Parents appreciated her advice and felt better equipped to support students at home:

Lo que trato de hacer, es algo que valoro mucho, es poder enseñarle al papá como puede ayudarnos en la casa. Y si él no puede, que una hermanita mayor, que una abuelita ... A los papás les doy herramientas para que puedan trabajar en la casa y les ayuden. De todas maneras acá con la maestra uno habla y todo. Pero a ellos les encanta tener esto. Y a los chiquitos los tengo con un bingo y una lotería. (Interview \#2)
What I try to do, is something I quite value, is to teach the parent how he can help us at home. And if he can't, an older sibling, a grandma ... I give parents tools so they can work at home and support [the student]. They talk to the teacher here. However, they like to have this. And I have the little ones with a bingo or lottery. (Interview \#2) 
When Diana was a classroom teacher in the dual-language program, she often invited parents to talk about their culture and experiences in Mexico, teach poems, lead activities,

etc.:

Hicimos mucho el contacto con la cultura de la que estaban aprendiendo ellos el idioma. Porque son niños anglos, son hijos de pronto gente que tiene raíces latinas pero ya aquí en los EEUU se olvidan de muchas cosas. Y los papás estaban muy motivados. Por ejemplo hicimos un mariachi. Los papás y las mamás nos ayudaron a pegar los botoncitos del vestido de mariachi ... otra mamá nos ayudó a coser las faldas de las niñas. O sea, la gente se metió mucho. (Interview \#2)
We made a lot of contact with the culture from which they were learning the language. Because they are Anglo kids, perhaps children from parents with Latin roots that have forgotten things in the USA. And the parents were motivated. For instance, we had a mariachi. The dads and moms helped sew the buttons on the mariachi dress ... another mom helped us sew the girls' skirts. In other words, people got involved a lot. (Interview \#2)

Gema was in constant communication with parents. She did home visits at the beginning of the school year to meet students' families and learn more about them.

Parents had her cell phone number and called her when they did not understand notes sent home, or when their children were sick or going through changes that impacted their well-being. Her classroom was always open to parents and found activities for them to do when they dropped in for a few minutes and offered their help. She talked at length about how to improve communication between school and parents. For instance, she saw the need to explicitly explain cultural differences to parents:

A veces hay conflictos en comunicar con los padres, por la cultura, verdad ... Los padres hispanos no entienden la cultura; a veces dicen-la maestra es muy fría ... Pero es parte de entender que la cultura americana es de una manera y nuestra cultura es de otra. Pero si no les decimos a ellos no
Sometimes there are problems communicating with parents, because of culture, right? . . Hispanic parents don't understand the culture; sometimes they say: "the teacher is too cold". . . But part of it is to understand that American culture has its ways and our culture has another way. But if we don't tell them they are not 
van a saber cómo trabajar con las maestras. (Interview \#1) going to know how to work with teachers. (Interview \#1)

She viewed herself as a bridge between parents and school. She educated

Mexican parents about the school system in the U. S. and created opportunities for teachers and parents to collaborate and get to know each other better. This was one of the reasons why she started and led a dance group with teachers and parents that presented traditional Mexican dances during a school assembly:

Y la otra razón que quiero envolver a los padres es porque quiero que los padres trabajen al nivel de los maestros porque muchos de nuestros padres tienen miedo, tienen vergüenza y no saben cómo integrarse. Entonces yo me siento como un puente entre los padres y la escuela. Yo siento que ese es mi trabajo aquí ... Yo siento que yo soy como un puente de comunicación y que también tengo que informar a los padres de sus responsabilidades pero también de sus derechos, porque no saben y no se atreven a preguntar. (Interview \#1)
The other reason why I want to involve parents is because I want them to work at the same level as the teachers because a lot of our parents are afraid, they are ashamed and they don't know how to get involved. So, I feel like a bridge between parents and school. I feel that is my work here... I feel I am a communication bridge and I also have to inform parents not only about their responsibilities but also about their rights, because they don't know and they don't dare to ask. (Interview \#1)

The collaboration among bilingual reading specialists and parents went beyond parents volunteering in the classroom. The activities for collaboration targeted and benefited three different audiences. In the first type of activities, parent collaboration benefited individual students. This was the most commonly used by all participants. Here are some of the activities that fit in this category: (a) informing parents about student progress or needs; (b) teaching parents literacy activities to do at home, either in schoolwide parent night literacy events or one-on-one conferences or individual meetings with parents; and (c) sending books or materials to practice literacy skills at home. In the second type of activities, parent collaboration benefited a class or group of students. This 
was done by participants who had their own classrooms and they invited or welcomed parents into their classrooms. This happened through mainly two avenues: (a) inviting parents to talk about their experiences and culture and (b) inviting or allowing parents to volunteer in the classroom. The last type of activities for parent collaboration benefited a larger group, namely the school. This happened when one of the participants invited parents and teachers to participate in a dance group for an assembly. She deliberately used dance as an experience to allow both groups to get to know each other and develop relationships. She also saw traditional Mexican dances as a way to value the Hispanic culture.

Collaboration with parents was often mentioned by participants. Parents were seen as partners in the education and literacy development of students. Parents and bilingual reading specialists needed each other to create the best possible learning conditions and support student biliteracy skills development and learning in general.

Participants collaborated and interacted with parents in their native languages, namely English and Spanish. These languages were used during instruction and had allotted times during the day. English and Spanish were both a means to communicate and also an end goal as students developed biliteracy skills. All participants talked about their experiences with language and reflected upon its importance in the schooling of students. In the next section I explore the second theme: language.

Language. The theme of language was mentioned by all participants during interviews. It appeared in 67 out of 177 units of meaning in the interview transcripts. The essence of language as it relates to the phenomenon of teaching biliteracy skills for these teachers related to how language was used in the district to support biliteracy, specifically 
Spanish in dual language programs. It is important to note that in this district Spanish is the native language for about $70 \%$ of its students. Participants saw bilingualism and biliteracy as an asset. Sally captured the essence of language and teaching biliteracy from the group and district goals in these terms: "It is about developing them [students] as a fully biliterate person who can read, write, speak, think and listen in 2 languages and do it really well" (Interview \#3).

It was mentioned several times that "biliteracy works" and Spanish was seen as more than an instructional language. Spanish was a vehicle to value the minority culture and to promote bilingualism among the Anglo community. Also, when teachers talked about language as part of their efforts to develop biliteracy skills, they noted that it was not sufficient to translate strategies or materials from English to Spanish. For instance, there are particularities to each language that do not necessarily translate into culturally relevant or appropriate literature when directly translated from English to Spanish. Likewise, there are certain aspects of language that need to be considered when looking at literacy programs developed in English that are available in Spanish. For example, rhymes do not carry the same importance in Spanish as they do in English and word families work differently in both languages.

The significant statements grouped under the theme of language represented different aspects of the district's organization and implementation of Spanish literacy instruction to support biliteracy. Namely, as shown in Figure 6, participants discussed: (a) how professional development for literacy was not focused on Spanish; (b) program issues, such as time allocation for Spanish in the dual language program, or lack of sufficient quality materials in Spanish; and, (c) additive view of Spanish in school. While 
these aspects of language were brought up by all participants, some of them emphasized one aspect more than others.

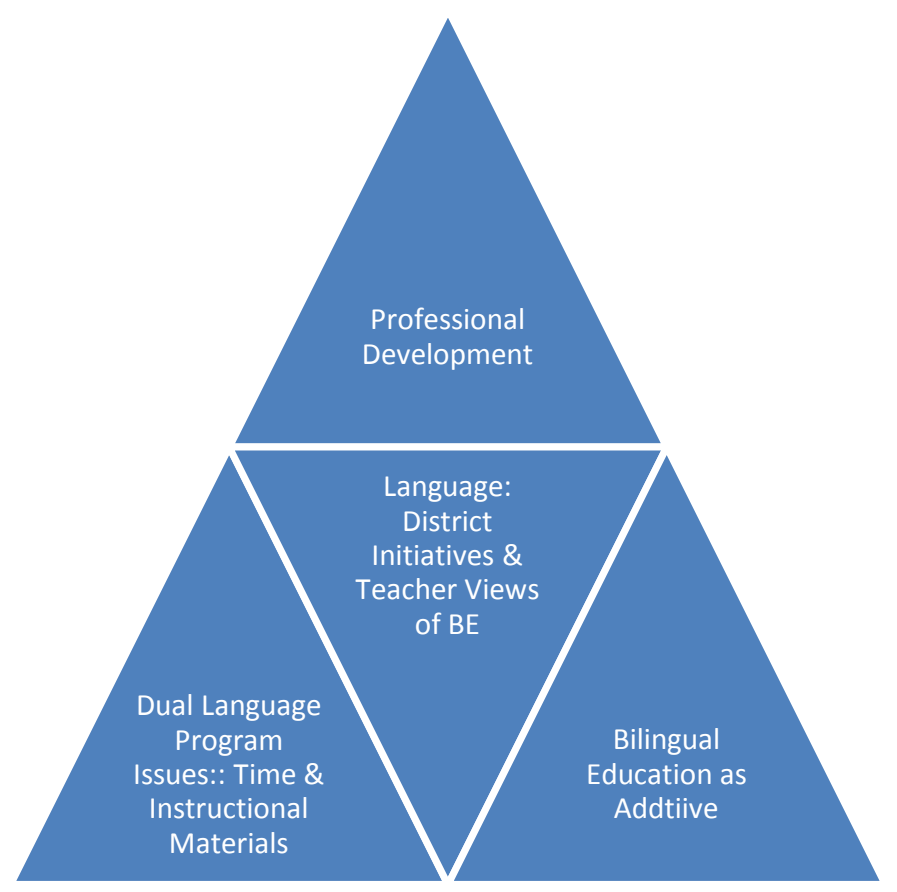

Figure 6. Language theme. This figure represents the areas in which the essence of language as it pertains to teaching biliteracy was discussed by participants.

Professional development is not focused in Spanish. Professional development not focused in Spanish was mentioned in 18 out of 177 significant statements. The current professional development the district had for literacy focused on the work of Pinnell and Fountas (2010) in the Continuum of Literacy and Learning. The program has components in Spanish that support literacy assessment up until second grade. Participants shared that while the consultant leading this professional development was an expert in literacy, she lacked the experience of teaching in bilingual settings with students acquiring literacy in their second language. In this district, there are native English-speakers in dual language classes who are learning to read in Spanish and native 
Spanish-speakers learning to read in English. Furthermore, having not taught in another language, the consultant was unable to address specific language questions pertaining to biliteracy or Spanish literacy. Participants felt frustrated by this fact and wished they would receive professional development in literacy specifically focused on Spanish and biliteracy.

Sally, Marie and Gema expressed a desire to receive professional development focused on Spanish literacy. While the district was focusing their professional development on literacy, the consultant who the district hired did not have experience teaching in bilingual settings or in another language besides English. All participants acknowledged how knowledgeable the literacy consultant was. However, when it came to discussing and teaching issues related to biliteracy she did not have enough experience. Marie shared:

She [consultant] has never taught in another language personally, so I think in some ways she is not always capable of providing that extra part ... We have people in the room, usually, that we come up with a Spanish counterpart, or what are we going to do with the Spanish. (Interview \#2)

This sentiment was echoed by Gema. She would have liked to have the literacy strategies modeled in a bilingual classroom where students are at a different proficiency levels in the target instructional language. She said:

Y hubo clases que ella [consultora] vino y modeló. Yo le dije, quiero que modeles en mi clase. Que me digas cómo. "Es que no puedo.” ¡Eso es lo que yo quiero saber! No que me digas así se hace, ¿cómo voy a hacer con los niños que no hablan español? ¿Cómo voy a hacer con los niños que están aprendiendo el idioma español que
And there were classes that she [literacy consultant] came and modeled. And I told her that I wanted her to come model in my class and tell me how to. "Well I can't" That is what I want to know! I don't just want to be told how to do it. How am I going to do it with the kids who speak Spanish? How am I going to do it with those 
hablan español? Porque no quiere decir porque mis niños hablan español ya tienen un buen nivel. Vienen bien fuertes en algunas cosas. Pero sobre todo con los niños que están aprendiendo el idioma, ¿cómo lo voy a hacer? Yo quiero que vengas y me digas, no que me digas cómo lo haga. Y nunca pudo venir a una clase [de español]. (Interview \#2) who are learning Spanish? It doesn't mean that my kids who speak Spanish have a good model. They come strong in some areas. Moreover those who are learning the language, how am I going to do it? I want you to come and tell me, not just to tell me how to do it. And she was never able to come to a [Spanish] class. (Interview \#2)

Participants shared how during the district's literacy professional development sessions,

bilingual teachers had to come up with the Spanish counterpart for literacy strategies or

skills discussed for English literacy instruction. Sally summarized it this way:

We work together to figure out what those things are. Like the coaches and the really strong teachers who are working with [consultant] will kind of talk through those questions [about Spanish] we have and think what our best educated guess would be. But, again, not everybody agrees and there is not somebody who really, truly is an expert. It is people who are in the practice, I guess, of doing it. (Interview \#3)

Participants would have liked to learn from an expert in the field of biliteracy instruction. They themselves had to translate literacy strategies in English into Spanish. They have worked together to learn how to teach literacy in Spanish but felt they needed more specific professional development in this area. Sally captured this need from other bilingual reading specialists in this district:

I've heard other bilingual reading specialists say this before, is that we could have more PD [professional development] around really how you teach literacy, reading in Spanish. Most of us have been primary teachers of Spanish. We just do what we think is the best thing to do. We read literature to try and get ideas about how to help them [students]. We use bits and pieces of some programs that we find that are helpful, like Estrellita, for example. But really, none of us learned how to teach exactly just Spanish, like how do you teach Spanish reading. We have never really learned that. (Interview \#2) 
In terms of further professional development opportunities, Marie and Gema expressed a desire to visit other schools, in the United States or abroad with dual language programs. Marie wanted to observe other schools with successful bilingual programs. She said: "I would like to see some other schools that are doing the same thing, and there are not very many, so just to go see some other schools that are teaching biliteracy" (Interview \#3). In addition to visiting other schools, Gema would have liked to work directly with well-known researchers in the field of biliteracy instruction:

A mí me gustaría estudiar con yo no sé, o ir a ver a primero programas afuera de aquí pues [distrito] es algo muy como un modelo, pero yo quiero ver qué hay afuera. O me gustaría trabajar un tiempo con la señora Escamilla o con la doctora Flores y ver qué están haciendo, cómo están creciendo en otros lugares, cómo transferir y compartir todo eso aquí. (Interview \#3)
I would like to study with I don't know who, or go to see programs outside ours. Here [district] is like a model, but I want to see what there is outside. Or I would like to spend some time working with Mrs. Escamilla or with Dr. Flores and see what they are doing, how they are improving in other places, hot to transfer and share all that to here. (Interview \#3)

Sally would have liked to attend bilingual education conferences to learn from those practicing and researching in this field:

I would love to have more professional development, to be able to go to La Cosecha, and CABE and NABE and all those professional development opportunities where you can learn from people who are in the field and who are researchers. (Interview \#3)

Furthermore, Diana felt frustrated that whenever she went to a literacy conference it took her a few days to translate materials or strategies before she could implement them in Spanish, unlike her English partner who was able to use strategies and resources right away. However, this had pushed her to be more creative and resourceful to serve the needs of her students. She shared: 
Porque siempre me toca cuando tomo clases aquí, [preguntar si] tienen para español? Nada. ¿Eso está en español? No. So, siempre estoy con esas. Se puede aplicar y siempre estoy haciéndole adaptaciones. Pero ves cantidad de cosas bonitas y vamos juntas, ella [especialista de lectura en inglés] para inglés y yo para español y ella puede aplicar al otro día y yo tengo que empezar a traducir. Pero eso me ha ayudado también a ser creativa porque si empezado a crear mis propias cosas y a usarlas con los niños. (Interview \#1)
Because every time I take classes here, [I ask] do you have this in Spanish? Nothing. Is this in Spanish? No. So, I am always asking. You can apply and I am always adapting. But you see so many nice things and we go together, she [English reading specialist] to English and I to Spanish and she can apply things the next day and I have to start translating. But this has helped me to be creative because I have started to create my own things and use them with the kids. (Interview \#1)

She was interested in learning more about how the brain works and supports language

and literacy acquisition:

Me interesa mucho ver en el cerebro qué procesos se pueden maximizar. Yo sé que hay muchas cosas, todo lo de los cognados y hay muchas cosas como proceso que se hacen en el cerebro. Esto que te decía de cómo los niños pueden aprender una lengua y si tienen alguna dificultad para spelling, porque inglés es mucho spelling ... quiero profundizar un poquito más en el desarrollo del cerebro y cómo puedo maximizar algunas cosas con ejercitaciones. (Interview \#3)
I am interested seeing in your brain what processes can be maximized. I know there are many things, with cognates and many other things such as processes in the brain. I was telling you about how kids can learn a language and if they have difficulty spelling, because there is a lot of Spelling in English ... I want to learn more about brain development and how to maximize things with exercises. (Interview \#3)

A desire for professional development for teaching literacy in Spanish and biliteracy was mentioned as important by all participants. Another aspect mentioned under the theme of language dealt with program issues. These program issues were the instruction time spent in Spanish and the materials available in Spanish. 
Program issues-about instruction time spent in Spanish and lack of appropriate materials in Spanish. Program issues were mentioned in 16 out of 177 units of meaning. Participants acknowledged that students live in an environment where English is dominant. They saw biliteracy as additive, yet they were aware that literacy instruction in Spanish had less time when compared to the overall instruction in English that students would receive during their K-12 education. For this reason, they felt compelled to help students learn to read in Spanish and transfer those skills into English in a natural and rapid manner. They wanted students to develop a solid academic foundation in Spanish to transfer it to their second language. They did not want to see Spanish skills decrease but rather increase over time. In terms of materials, books in Spanish were not as widely available as books in English. Participants also identified problems with direct translations that were not culturally relevant to Hispanic students or with terms in Spanish books from other countries for which students did not have enough familiarity and did not know their meaning.

Diana thought that the amount of instruction in Spanish diminished quickly and did not allow enough time for Spanish to become strong given that by third grade students spend 50\% of their instruction in English. She shared that Spanish teachers pushed their students hard in the primary grades to solidify literacy, grammar, and other aspects of Spanish:

Lo que yo sentía es que tenemos poco tiempo para instaurar el lenguaje [español] fuerte. O sea que había que subirle, tener siempre unas expectativas altas en ellos [estudiantes hispanos] porque pronto, pronto, su
I felt that we had short time to establish a strong [Spanish] language. In other words we had to elevate it, always having high expectations for them [Hispanic students] because soon, soon, their language was going to reduce in 
idioma va a mermar en porcentaje durante el día; en tercero es 50/50. Y en parte es por eso ... siempre al estudiante hispano se le pide un poquito más. (Interview \#3) percentage during the day; en third grade is 50/50. In part, that is why ... we always ask more from the Hispanic [student]. (Interview \#3)

She felt that part of the early transition to more English instruction time was due to external pressures such as the Oregon Assessment of Knowledge and Skills (OAKS) exams in English that started in third grade. To address the need for more appropriate books in Spanish, Diana did two things: (a) she brought books from Latin America and (b) she created materials in Spanish with students using the Language Experience Approach (LEA) to support literacy acquisition. The LEA is a whole language approach to literacy that uses students' orally produced text to support literacy development. Students create and dictate a story or narrate an experience that the teacher writes down. This text is then used as reading material by students (Collier, 2008). Diana shared the following:

El hecho de enseñar español en un idioma donde estamos inmersos en inglés a veces no es muy fácil porque no encontrábamos muy buenos materiales. Y los tuvimos que elaborar. Pero el hecho de tener que elaborarlos fue también más auténtico. Han sido más auténticos y podemos elaborar con los mismos niños. Por ejemplo el Language Experience es muy fácil. Tenemos allí todo y sale de ellos y no necesitamos mucho. (Interview \#3)
The fact that we teach Spanish in a language where we are immersed in English is not always easy because we were not finding good materials. And we had to create them. But the fact that we had to create them made them also more authentic. They have been more authentic and we can create them with the students. For instance, the Language Experience [Approach] is very easy. We have everything there and it comes from the kids and we don't need much. (Interview \#3)

Marie and Gema noticed that books translated from English to Spanish were not always culturally appropriate for Hispanic students. The humor did not necessarily translate and there were differences in the way people use language that their students did 
not understand. As a bilingual reading specialist, Marie's perspective for evaluating

books has changed. She shared the following about translated books:

You get a lot of the perspective of what it is like to read books that have been translated from English into Spanish, because we do that a lot, and the differences in literature, the differences in the way people use language. . . . Sometimes you just notice a lot of what is culturally appropriate to one language or another language ... When I first started reading Junie B. Jones with little kids in Spanish, they wouldn't get the humor because it was like, Why is she acting so disrespectful? It wasn't really funny. Then the things that they translate directly would not really come across. (Interview \#3)

These inadequate translations not only appeared in children's literature; they were also present in teachers' manuals. Participants shared that some of the literacy programs in Spanish did not take into account language differences. For instance, some of the word skills work in English appeared in the books for Spanish where they were not as relevant. Referring to books she used Marie shared:

In Spanish, many publishers use the ideas of English of what word work should be in Spanish. They have word work in here, but what they did for their word work, is they took the English ideas of what word work should be and they just translated it kind of into Spanish and then they tried to find words that would need-to me it looks like they have made the transfer into Spanish, thinking of the ways we teach English. Whereas teaching Spanish, you might want to change some more things, make some changes. (Interview \#3)

Gema felt frustrated about how publishers minimized language differences and presented materials developed for English into a Spanish translation. About the lack of specific bilingual literacy programs she shared:

[Acerca de los programas de lectura en inglés] Hay miles de programas que te dicen [cómo enseñar lectura] pero no bilingüe. Y el hecho de enseñar el otro idioma implica todo un mundo de diferencias ... Es como yo digo a veces, es que no puedes traducir...
[Referring to literacy programs in English] There are thousands of programs that tell you [how to teach reading] but not bilingual. And the fact to teach in the other language implies a world of differences ... Is like I say sometimes, you can't just translate ... 
Así no es el idioma. No es una traducción. (Interview \#2)
Language is not like that. It is not a translation. (Interview \#2)

In addition to lack of materials in Spanish, Sally faced instructional time

constraints when her students switched instruction time in the dual language program from Spanish to English literacy. She worked with the Spanish teacher in her role as instructional coach and saw students only for a few weeks before they went to work with the English teacher for literacy. She saw this lack of continuity as challenging:

I have to deal with a lot of the programmatic issues that teachers deal with, like the fact that they swap students every 2 to 4 weeks. They have a whole different group of kids, so it is kind of tricky, because I'll be working with a teacher and we will be getting to know a group of readers together and making all these moves, and then all of a sudden I won't get to see them for 4 more weeks because they are with the other teacher. There is definitely format kind of issues you deal with when you are a bilingual reading specialist. (Interview \#3)

Participants would have liked to have enough time and materials in Spanish to further develop students' literacy skills in two languages. They saw biliteracy as additive.

Additive view of Spanish in school in support of bilingual education. Additive view of Spanish appeared in 33 out of 177 units of meaning. Participants saw bilingual education as an additive model. They thought that biliteracy was beneficial for all students, native Spanish-speakers and native English-speakers. Bilingualism and biliteracy better prepared both groups of students for the future. They saw bilingualism as a right for both groups. For Hispanic students, it valued and used their native language in instruction; for Anglo students, it allowed them to access a second language similar to what students in other parts of the world do.

Sally changed her view of bilingual education from a transitional model to an additive model over the years. When she first started teaching in a bilingual classroom, 
she thought that she was going to help Hispanic students make the transition to English in a transitional program. However, she was later able to use Spanish as an asset as students developed both languages at the same time in dual language programs:

Now I know that what really needs to happen for students who want to come out of school biliterate, they need to have two languages developed. Primarily, I think the best way to do it is by developing learning to read in their first language first, and then their second language, you can add that on. But when I first started, I didn't really understand bilingual education. Basically I was thinking of it more as an early exit thing. I was thinking that, oh, when I am working with bilingual students, I'll give them their Spanish instruction so they can learn the English instruction and it was a very egocentric view of bilingual education. I'm not that kind of person, but that is just all I knew. I thought that was what we were doing, trying to teach them English, right. Then once I started doing it, I realized, oh, my gosh, this makes them so powerful. They are learning their first language and if we keep going with that and push it all the way through and do it together, do both languages together all the way through school, they are going to be so much more powerful because they think at such a deep level in their first language. (Interview \#3)

She thought that bilingualism and biliteracy made students' literacy skills stronger. She mentioned how her ability to speak Spanish allowed her to access high-level English words that had Latin roots. Sally saw the benefits of biliteracy in her own children; they surpassed their monolingual peers in English were also able to read in Spanish. She shared:

My daughter, [name] is in 5th grade. She is reading at the 9th grade level in Spanish. I'm really proud. I know, she is qualified for TAG because of that, partly. And my 2nd grader is reading at about a 3rd grade level right now ... She is one level above where she should be and in English she is a year ahead. Biliteracy works is my statement. (Interview \#2)

Diana advocated for bilingual education. She saw bilingualism and biliteracy as a way to be better prepared for the future. Biliteracy skills not only enriched students' 
personal lives but also prepared them for the future job market. This is what she would tell legislators and other stakeholders about bilingual education:

[El bilingüismo] es una oportunidad maravillosa, que le permitan acceder a los jóvenes a este tipo de educación. Que no es quitar, la gente cree que le quitan el tiempo de conocer el inglés.

No. Es agregar, no es quitar, es agregar

... Es enriquecedor para las vidas personales de ellos, para la vida profesional en un futuro y para la vida laboral también. Porque en el futuro ellos tienen la facilidad de poder acceder a trabajos que hoy en día el sistema, el medio, está demandando más jóvenes que sean bilingües.
[Bilingualism] is a wonderful opportunity, let the youth access this type of education. It is not to take away, people think that it takes time away from learning English. No. It is to add, it is not take away, it is to add on ... It enriches their personal lives, their professional live for the future and also their work life. Because in the future they will have the ability to access jobs that nowadays, the system, are requiring more youth to be bilingual. (Interview \#3)

She thought that bilingualism should be embraced in the U. S. as it is in other parts of the world. For her, not supporting bilingual education was a mistake:

El bilingüismo está dado para la sociedad del futuro. O sea, querer tapar aquí en EEUU y decir que los niños solamente pueden aprender inglés es un error garrafal. (Interview \#3)
Bilingualism is for the society of the future. That is, to try to block it here in the USA and to say that children can only learn English is a huge mistake. (Interview \#3)

Gema thought that all her students, native-English speakers and native-Spanish speakers, had the right to learn two languages. The world had changed and children needed more than one language today. Here is what she would share with legislators and other stakeholders:

Yo les diría que es una necesidad, biliteracy es una necesidad no solamente para los niños que hablan español, para todo mundo. Porque el
I would tell them that biliteracy is a need, not only for children who speak Spanish but for everyone. Because the world is changing but more than 
mundo está cambiado pero más que nada es por la riqueza porque los niños, es la riqueza de la educación. O sea los niños crecen no nada más en los idiomas, crecen en matemáticas ... Tienen todos los derechos de aprender, tienen todo el derecho de aprender en su idioma y los niños que no hablan el idioma tienen todo el derecho de aprenderlo. Todos los países del mundo hablan más de un idioma, excepto aquí casi. Entonces es una necesidad, es una realidad y es un derecho de los estudiantes. (Interview \#3) anything is a richness because of the children, is the richness of education. In other words, children don't only grow in two languages, they also grow in mathematics ... They all have the right to learn, they have the right to learn in their language and the children who don't speak the language have all the right to learn it. All countries in the world speak more than one language, except here almost. Then it is a need, it is a reality and a right for all the students. (Interview \#3)

Gema was also purposeful about elevating the status of Spanish in her dual

language class. She asked her Hispanic students to become language models and teach

Spanish to her native-English speakers. She saw how this brought pride to her minority

language students and promoted their self-esteem and confidence. This also created a

community of learners where students took a more active role in their learning. She

shared:

Ya no son los niños [hispanos] los que siempre están aprendiendo. Yo les digo a mis niños, a ver ahora tú le vas a enseñar a él cómo se dice, ahora tú le vas a mostrar y tú le vas a platicar. Entonces ya cambió, ya el inglés no está en poder sobre el español. Por lo menos en estas clases es igual o el español está dominando. Los niños son maestros y son los modelos; y entre ellos mismos enseñan. No solamente yo. (Interview \#3)
[About Hispanic students] It is not the kids who are always learning. I tell my children, now you go and teach him how to say it, now you will show him and you will talk with him. Then it has changed, English is not in power over Spanish. At least in these classes is equal or Spanish is dominating. The children are the teachers and the models; and they teach each other. Not only me. (Interview \#3) 
Marie shared how developing literacy in Spanish supported students' transfer of literacy skills to English. She saw this often with students who had strong literacy skills in Spanish:

I think I do see the kids really transferring those skills and people don't believe that sometimes. I do feel like I've seen a lot of kids come and they are reading pretty well in their native language. They pick up the English and if that motivation is there and have that confidence, that helps them a lot with the biliteracy. I think it is very important that we have it, really have biliteracy for kids. (Interview \#3)

In fact, she has seen Hispanic students who did not receive biliteracy instruction in other districts who were behind in literacy compared to her students. She was saddened by this fact and felt that Spanish-speaking students who did not receive literacy support in Spanish were left behind compared to kids that have been in bilingual programs. About biliteracy she said:

I think it is just better . . it just opens up a lot of doors for people to be biliterate. It is definitely better to have biliteracy, and the kids learn how to read so much more quickly. I've seen kids, when I do go to other schools, who are not having much help for kids who come in, native speakers of Spanish, and I've seen how much progress they have made in their reading. I'm really sad almost about it, because sometimes I feel that they have just been left behind. (Interview \#3)

The theme of language related to the district's organization and implementation of its dual language programs. Namely, professional development efforts that pertained to literacy, time students spent learning in Spanish, materials available in Spanish. The theme of language also revealed how participants viewed bilingual education and biliteracy. The organization and program decisions made at the district level influenced the experiences participants had with biliteracy in regards to language. The literacy efforts put forth by the district, although not always specifically designed to support 
literacy in Spanish, had students' literacy development as target. This is exactly what emerged as the essence of teaching biliteracy in the third theme: bilingual reading specialists carefully created a literate environment (IRA, 2010) to support their students' biliteracy development. In fact, they provided an invisible support intended to boost students' identity as readers.

Caring. This theme appeared in 47 out of 177 units of meaning from the interview transcripts. The essence of caring, as it related to the phenomenon of teaching biliteracy for participants was about engaging students during reading instruction, developing students' self-esteem, and motivating students to become readers. Participants cared about creating a supportive and engaging learning environment, which took into account the emotional needs of students and their well-being. Bilingual reading specialists were interested in improving students' reading skills and motivation as well as their self-esteem as they developed biliteracy. Participants celebrated student successes when they attained new reading skills-no matter how small they seemed-and made learning fun. They also facilitated change in students' attitudes toward literacy, helping them feel like successful readers, motivating them to read and see reading as useful-with real life applications-and not just a school mandated activity. The essences represented in this theme are below in Figure 7. 


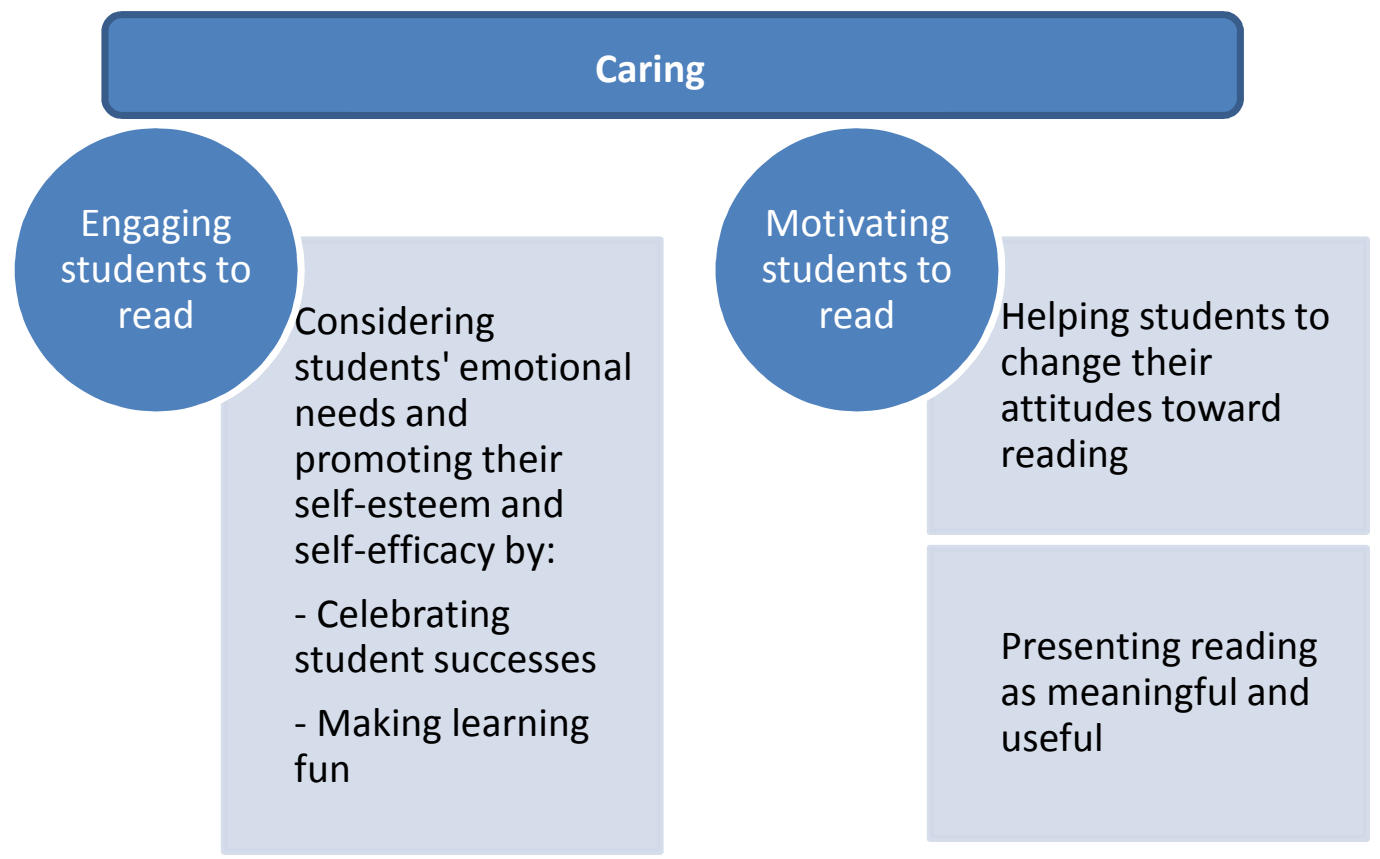

Figure 7. Caring theme. This figure represents the areas in which the essence of "caring" was discussed by participants.

Engaging students to read. Engaging students to read was mentioned in 18 out of 177 units of meaning. Participants recognized that readers who were struggling in reading were aware of their difficulties, felt frustration, and often had low self-esteem. They were aware of students' emotional state and feelings of frustration when they were not reading as well as their classmates. For this reason it was important for participants to celebrate student successes as they practiced and acquired reading skills, even if these gains seemed small, in order to boost their self-esteem. This created a positive and safe environment for learning. They also capitalized on students' strengths. Bilingual reading specialists wanted to engage students in reading and wanted students to have fun while in their reading groups or during literacy instruction. To this effect, they used plays, songs and interesting visual materials to support literacy development. Participants wanted 
students to enjoy reading and maximized the time they had with reading groups, creating positive learning experiences for students.

Marie incorporated repetition through reading plays and had students act out their readings. This supported fluency development in reading and allowed students to focus on the actual reading and its meaning rather than on decoding difficult words. Once students were able to read and act out the plays, they started to understand the humor from the readings and had a great learning time and experience during their reading groups. She recalled one of many instances when acting out helped students understand a play:

We are reading the play. We are all sitting down and we were starting to-I don't know how often I did this. I think I just said, we are going to act this out. We started to act it out and we did it and did it. It was so funny because it was a really funny play, but the kids were not really getting the humor. Then all of a sudden they are acting it out and acting it out, and then like, oh, they just started laughing. Then as we went along, they [the kids] just started laughing more and more because they were starting to get the humor . . . and it just took acting it out and doing it repetitively, and I could just see how their comprehension just went way up on this play and repetition. It was really good for them and really fun. We had a great time. We were just laughing. We had such a good time. (Interview \#2)

Diana thought that her attitude and approach set the tone for an engaging and enjoyable learning environment. She celebrated students' accomplishments during reading groups. She also brought interesting and engaging materials to get students' attention. She had puppets to support the use of different reading strategies, magnifying glasses and pens with magic ink during her reading intervention groups. These kept students engaged and excited while at the same time reduced their frustration. She said:

Tiene que ser muy recursiva porque a veces no tenemos todos los medios. Tiene que ser ameno, agradable para los niños. Tiene que ser una maestra
You have to be very resourceful because sometimes we don't have all the means. It has to be fun and enjoyable for the kids. It has to be a 
divertida porque de hecho estos niños tienen la frustración. Ellos ya saben que no son capaces como los otros, ya se han identificado, su imagen está muy pobre. Entonces aquí tenemos que subirla, mostrarle que ellos pueden y pues el refuerzo positivo siempre. Ser alegre, tener la capacidad de celebrar cada esfuerzo de que ellos hagan. Cualquier cosa hay que hacerles porque para ellos es lo máximo y es verdad para ellos en ese momento es lo máximo y hay que celebrarles esos momentos. (Interview \#3) fun teacher for these kids are frustrated. They know they are not as capable as the other kids, they have been identified, and their self-image is low. So we have to raise their selfimage, show them that they can and use positive reinforcement always. Be joyful, have the capacity to celebrate each effort they make. Anything to celebrate because for them it is great, and it is true that it is great in that moment and we have to celebrate those moments. (Interview \#3)

When Diana was teaching in the dual language class, she used visual support to make Spanish comprehensible to her native-English speakers who felt frustrated at first when they did not understand Spanish. She used sheltered strategies to reduce students' anxiety. She deliberately used these strategies as a way to address students' emotional needs and make the content accessible for students who were learning in a second language. She shared:

Pero hay mucha cuestión emocional en esos English-only y no lo quería dejar pasar ... Pero luego los niños van mermando la ansiedad en la medida que usas más visual. Yo aprendo mucho visualmente y trato siempre de poner visual para los niños, o sea el visual, el lenguaje del cuerpo, todo eso ayuda para hacernos entender y yo uso mucho que el niño pueda entender la idea y luego pueda analizar las partecitas de las oraciones y poder descomponerlas. (Interview \#1)
There are a lot of emotional issues among English-only and I did not want to ignore it ... But then the anxiety among children reduces as you use more visuals. I learn a lot visually and try always to use visuals for children, that is visual, body language, all of that helps to make ourselves understood and I use a lot so the child can have the idea and can then analyze the small parts of sentences and break them down. (Interview \#1)

Gema spent time getting to know her students and took into consideration their emotional state during the day. She was concerned about her students feeling frustrated if they could not read and focused on students' strengths. She recognized students' 
accomplishments and celebrated their successes. She also used materials with visual support to develop Spanish for her native-English speakers and literacy skills in all her students. She was careful and deliberate about helping students with their self-esteem:

Si no aprecias cada cosa que el niño hace, le va a afectar en su autoestima también. Va a sentir que yo no puedo. Y a esta edad eso es grande porque cuando empiezan a leer y hay chiquitos que no pueden, se cierran, se bloquean, [dicen] "yo no puedo hacerlo." Entonces tienes que encontrar las maneras para que todo mundo resalte en lo que ellos puedan hacer. (Interview \#2)
If you don't appreciate everything the child does, this will affect his self-esteem. He is going to feel that he can't. And at that age that is huge, because when children start to read there are kids who can't and close themselves up, they get blocked, [they say] "I can't do it." Then you have to find ways so that everyone shines in what they can do. (Interview \#2)

She individualized her instruction targeting specific student needs and valued students'

own progress. She shared:

... tienes que valorar el crecimiento del niño en sí mismo. Porque puede ser que no crece como los demás pero puede crecer en su mismo ser. O si puede ser crecimientos gigantes, más que ninguno en la clase. Aunque no llegó al nivel pero quiere decir que ese niño creció mucho más que todos de con el nivel de como venía. Entonces eso me ha enseñado a individualizar cada niño en su crecimiento y me ha ayudado a crear o a aplicar intervenciones para cada niño o cada necesidad. (Interview \#3)
... you have to value the growth in itself. Because it may be that the kid does not develop as the others but it develops in himself. Or it could be giant developments, more than any other kid in the class. Even if he did not reach the level but it developed a lot more than the rest with the level he first had. Then it has taught me to individualize each child in his growth and it has helped me to create or apply interventions for each child or need. (Interview \#3)

Sally celebrated student successes and felt overcome by joy when they were enjoying reading. She liked seeing students celebrate their own progress as their reading skills improved. Like Marie, she also saw how students were able to enjoy their reading 
material once they acquired more fluency. About the joy she experienced when students started making sense of what they read, she shared:

As they progress and get out of the baby reader stage, they start to be able to read books that don't have patterns and stuff. It is exciting to watch them get to funny parts and they start to understand that it is supposed to be funny and you are supposed to laugh. They are just so cute because they are trying so hard to read it. And then they, ha, ha, that was funny. I love, love, love to watch them get to that point. It is fun. I really enjoy watching that happen and being a part of it. (Interview \#3)

She also shared an example of a student who was proud of his reading progress and was developing self-efficacy:

He [a student] told me, I don't ever want to learn to read, just a few weeks ago. Really, he is just about probably a week ago, the light kind of came on. Now he is so cute, because he is really proud that he is able to do it. So we were kind of practicing some high frequency words today, just to see if they could read them in isolation but also could identify them in the text. He was just right on the ball . . He was so proud because he figured out the word dame [give me] today, he is like that is dame. I said, how did you know? He said because it has a $d a$ and it has a me, dame. He was so excited. (Interview \#3)

Motivating students to read. Motivating students to read was mentioned in 29 out of 177 units of meaning. Participants motivated their students to read. They motivated their students to read by providing focused and individualized interventions that support readers who were struggling. They helped students change their attitudes toward reading as they became more skilled at reading. They also provided students a reason for reading. Participants wanted their students to become lifelong readers who enjoyed reading and were successful at reading. For them it was important that students changed their perception of reading from a school requirement task to a meaningful way of gaining information or enjoyment. 
Diana set up reading goals with her students. She wanted them to have a focus for improving reading and to feel successful as they were reaching that goal. Often times this involved the student committing to read at home. She also asked students to think about what they wanted to be when they grew up and pointed out how reading was necessary to accomplish that goal. She shared:

Yo trato con ellos de hacer una meta. Ellos cuando llegan el primer día aquí hacemos la meta. Ok. ¿Qué quieres [lograr]? Entonces escriben su nombre, quién es su maestra, en qué grado y cuál es mi meta. Pues es leer bien, dice éste. Alonso es de primer grado y él quiere ser equequeco [lee la escritura del niño]. Bibliotecario. Es uno que tiene que ver con estos libritos. (Interview \#2)
I try to set up a goal with them. The first day they come here we set up the goal. OK. What do you want [to accomplish]? Then they write their name, who is their teacher, in which grade they are and what is their goal. So it is to read well, says this one. Alonso is in first grade and wants to be a equequeco [reads the student writing]. Librarian. Is one that has to do with this little books. (Interview \#2)

Marie wanted students to become readers and found that finding the right book often helped students to get hooked on reading. She introduced different types of books for students and then sent them home so they could practice reading. Some of these books were for students to read to themselves or to a younger sibling. Others were for parents to read to them. She gave an example of how she finds the right book for her students:

I like to try to get them [students] to want to read and to enjoy it, so I'm always trying to find books that they would like and get them to be interested . . . there are certain books that I know kids like, because I have been doing it [teaching reading] for a while. I kind of know from that that there are certain books that they might like. It doesn't always work, though, and that is kind of funny. Sometimes I have had certain groups that will just love this book about, it is about the zoo, and it is the most simple book, counting balloons and colors. Sometimes I read that and they are just crazy about it. They all want to read it. Then other times, there is no interest, but there are certain books that I will pull out like that. I have series books with the same characters and the kids love to read about the character. They will read on their own once they are interested. That is just a way 
to get them hooked into reading, and they can take them home most of the time. (Interview \#2)

Sally also focused her instruction based on student needs to ensure they were able to make progress. She motivated students to read and liked to change their attitudes toward reading by helping them feel successful at reading. She shared how she provided instruction in Spanish and English for a few weeks to change negative attitudes toward reading Spanish from a native-English first grader to support her biliteracy skills development. This is what she shared about the student:

There is this little girl that I worked with last year, she just really touched me. She is English dominant and she was in a Spanish classroom, first grade, and she for all of kindergarten and probably half of first grade, she refused to speak Spanish. She said she didn't want to learn it, she hated it, she was miserable in Spanish. She constantly spoke English to teachers . . But anyway, because of her bad behavior in kindergarten, she didn't learn much English reading either. So she got to first grade and still hated Spanish, couldn't read in English at all, not at all. I started working with her teacher ... Then when she would do something, read something in Spanish, we would call her up to the front, Could you read this to the class? She just started to brim with pride and I'm learning Spanish. Now she tells everybody, I like Spanish, Spanish is awesome and I can read in Spanish. Anyway, we also started working with her on her English reading. Once she got over that Spanish sucks attitude she had, she started to pay attention to the lessons. She started to want to learn to read in Spanish. Then once she started to want to learn to read in Spanish, she really wanted to learn to read in English, because that was her strongest language. All her friends were reading these big books to her, like big kid books, and she was just reading the baby books. We started working with her. We pulled her for English time, too. We made a decision that we would pull her for part of the time to work in English so she could catch up. The light started to come on and she turned and she said, I love to read. I was like, well, good. She was so excited. She ran out of the classroom and school was out, and she was telling every teacher, I can read now, I am a reader. It was so cute. That kind of thing just makes it all worth it, when you can take a kid who thinks they hate everything and make them believe in themselves. I just love it. It is awesome. I love my job. (Interview \#1)

She loved how students changed their behavior and became more independent and secure as their sense of self-efficacy improved. Here is what she shared: 
It is so exciting when they finally have that independence. When they are first learning, they are just constantly [pause] they will read a word and then look at me, and then read a word and look at me, and then read a word and look at me and read a word and look at me. It is like, you can do this. Just stay focused on the text. Then once they get it, it is a different degree of, Look at me, teacher, look at me, because they are like, oh, my gosh, I can read! Look at me! (Interview \#3)

Gema helped students make connections between their lives and literacy in her class in order to motivate them to read and develop self-efficacy. She talked to students about reading strategies as tools for literacy they could use as they developed literacy. She told students those strategies were like super powers they could use as needed. She had icons to represent each strategy and posted these strategies in a visible place. She helped her students view themselves as readers, even though they were in the early stages of acquiring literacy. She kept the reading strategies visible for students to refer to them: ... y lo que hago es que cada vez que yo hablo de una lección pongo la estrategia aquí [cartelera]. Y luego los niños pueden referirse y hay diferentes. Y lo manejamos como si nosotros tenemos súper poderes. Y nuestros poderes están en la lectura. Entonces estas son algunas de las estrategias: leemos más rápido cuando encontramos patrones o leemos de corrido como patinando, que no vamos a brincar. Podemos tener la expresión y cómo los personajes en la historia. Pero antes de llegar ahí pues, decimos que las estrategias son nuestras herramientas de trabajo o son nuestros super poderes para leer.

(Interview \#2) $\ldots$ and what I do is once I teach a lesson I place the strategy here [pocket chart]. And then the children can refer to it and there are several. And we deal as if we have super powers. And our super powers are in reading. So these are some of our strategies: we read faster when we find patterns or we read as we are skating rather than skipping. We can have expressions like the characters in the story. But before we get there we say that strategies are our work tools or they are our super powers to read. (Interview \#2)

She motivated, supported and challenged her students to read. When they didn't feel confident, she encouraged them to read by using the strategies they have learned: 


\begin{abstract}
Ahorita estamos muy fuertes con ¿cómo leo, qué hago cuando leo? Pues hago estos pasos: leo en voz baja, susurrando, me quedo en el mismo lugar, mis ojos tienen que estar al libro y elijo un libro que sí me interesa ... Entonces vienen y te dicen-ay yo no puedo leer, yo no sé leer. Entonces ahorita estamos mucho con que-sí puedes leer, hay tres maneras de leer libros. ¿Cómo leemos libros? Mirando las ilustraciones, puedo leer las palabras que ya conozco, o puedo contar la historia. (Interview \#2)
\end{abstract}

We are now very strong about how do I read, what do I do when I read? Well I do the following steps: I read quietly, whispering, I stay in the same spot, my eyes are looking at the book and I choose I book in which I am interested ... So they come and tell you, I can't read, I don't know how to read. Then we are working with yes you can read, there are three ways to read a book. How do we read? Looking at the pictures, I could read the words that I already know, or I can tell the story. (Interview \#2)

Participants cared deeply about students. They wanted students to feel successful and to develop biliteracy skills. Participants mentioned several times how important it was to figure out what was going on with readers who struggled in order to address specific needs and help them close that gap. This was a continuous assessment process as reading specialists identified new behaviors or skills to focus their instruction as they worked closely with students. Diana mentioned that it was possible to pay close attention to students reading behaviors when working in small groups but that reading sessions were very demanding, in part due to the short time reading specialists had to work with students. This sentiment was echoed by Marie. Bilingual reading specialists had student learning and well-being as a priority. All of them mentioned how students' success motivated them to work and how they enjoyed seeing students improving and developing biliteracy skills.

The three themes unveiled from the interview transcripts -collaboration, language, and caring-represent how participants understood and experienced teaching 
biliteracy. Their experiences took place within the same school district in three elementary schools. Participants' efforts aimed at developing in students a love for reading as well as equipping them with the necessary skills to become independent and successful readers in two languages. Below I analyze how these experiences were distinct for participants in terms of how often they brought up each theme during the interviews.

\section{Analysis}

According to Van Manen (1990), themes help researchers to make meaning of the particular phenomenon they are trying to understand. I gained insight from the participants' experiences by identifying the themes discussed above. Table 3 shows how each participant discussed the themes in similar and distinct ways, emphasizing some themes more than others, according to the number of times each theme was identified.

\section{Table 3}

Frequency of Themes Represented in Significant Statements

\begin{tabular}{|l|c|c|c|c|c|}
\hline Theme & Marie & Diana & Sally & Gema & Total \\
\hline Collaboration & 11 & 17 & 17 & 18 & 63 \\
\hline Language & 10 & 11 & 18 & 28 & 67 \\
\hline Caring & 10 & 14 & 17 & 6 & 47 \\
\hline Total Significant Statements & 31 & 42 & 52 & 52 & 177 \\
\hline
\end{tabular}

I present below an analysis of the distinct experiences based on the number of times these themes and subcategories were brought up during the interviews by each participant. 


\section{Analysis of Distinct Experiences}

Language and collaboration were the themes that participants brought up most often during the interviews. Language was captured 67 times and collaboration 63 times. The theme student learning was captured in 47 units of meaning. Table 4 represents how the units of meaning were clustered among each theme and subcategories. Collaboration had the highest number of units of meaning for Marie and Diana, who had 11 and 17 units of meaning, respectively. They both work as reading specialists in their schools. For Sally and Gema it was the theme of language that was identified more often, with 18 and 28 units of meaning respectively. Sally is an instructional coach and Gema a classroom teacher.

The amount of units of meaning in each theme was evenly distributed for Marie and Sally among the three themes identified in this study. Marie had one more significant statement for collaboration (11) than for the other two themes (10). Sally had one more significant statement for language (18) than for the other two themes (17). Diana had a variety of units of meaning for all themes, ranging from 17 for collaboration to 11 for language. Gema had the highest and lowest number of units of meaning from all the participants for a particular theme; language appeared 28 times while caring appeared only 6 times. 
Table 4

Frequency of Themes and Subcategories Represented in Significant Statements

\begin{tabular}{|c|c|c|c|c|c|}
\hline $\begin{array}{l}\text { Theme: } \\
\text { Subcategories }\end{array}$ & Marie & Diana & Sally & Gema & Total \\
\hline Collaboration & 11 & 17 & 17 & 18 & 63 \\
\hline Collaboration with teachers & 6 & 2 & 14 & 5 & 27 \\
\hline Collaboration with parents & 5 & 15 & 3 & 15 & 36 \\
\hline Language & 10 & 11 & 18 & 28 & 67 \\
\hline PD not in Spanish & 2 & 2 & 8 & 6 & 18 \\
\hline Materials \& time & 5 & 5 & 2 & 4 & 16 \\
\hline Additive view of $\mathrm{BE}$ & 3 & 4 & 8 & 18 & 33 \\
\hline Caring & 10 & 14 & 17 & 6 & 47 \\
\hline Engaging students & 3 & 6 & 5 & 4 & 18 \\
\hline Motivating & 7 & 8 & 12 & 2 & 29 \\
\hline Total Significant Statements & 31 & 42 & 52 & 52 & 177 \\
\hline
\end{tabular}

Below I present a short analysis of the themes for each participant, which takes into consideration each participant's context as reading specialists, classroom teachers or instructional coaches.

Marie. For collaboration, Marie had six units of meaning regarding collaboration with teachers and five units of meaning for collaboration with parents. The subcategory of motivating students to read under the theme of caring had seven units of meaning, the 
highest one for Marie. Both collaboration with teachers and motivating students to read complement each other when we consider that for Marie the essence of a bilingual reading specialist was to hook students on reading and instill in them an inner motivation to read. She is the only reading specialist at her school of around 500 students. Her efforts to support readers who struggle were complementary to what classroom teachers did to support biliteracy development. In this regard it was important for her to create opportunities to collaborate with teachers and instructional assistants to address student needs.

Marie's school had several reading specialists in the past but these positions were eliminated due to budget cuts. During the interviews, Marie shared that her job was stressful, in part because she was the only one serving the needs of so many students without sufficient time. However, she also mentioned that she liked her work and she worked with wonderful teachers who did everything they could to support students:

I have been here awhile and I feel good about [pause] I think the people here who are working are really trying to do our best with the kids. We have all these constraints but we are still trying to make it work. (Interview \#2)

The constraints she was referring to were shortage of time, being the only reading specialist for the school, and having three school initiatives that divert the school efforts in different directions. Nonetheless, she was committed to working with minority students and wanted to benefit the population at this school district.

Diana. The majority of Diana's statements concerned collaboration. More specifically, out of the 17 significant statements she had for this theme, 15 pertained to the collaboration with parents. For her, it was important to obtain parental support and to 
provide parents with the necessary tools and skills to help their students develop literacy. In her role as a reading specialist, she created opportunities to spend time with parents talking about their students' progress and sharing their reading goals. She mentioned how important it was to work with the parents of readers who struggle because they were the ones that needed support the most. She said that parents were aware of the student difficulties but did not know how to support them. Therefore, they valued the resources she shared with them. She shared:

Los papás saben que tiene problema. Parents know he has a problem. I tell Y le digo-bueno, usted qué puede hacer? Esto y esto. Entonces sí les them "Well, can you do? This and gustó que les diera la lotería y el bingo porque dan una mano para ellos. No saben, dicen-maestra yo no sé cómo hacer esto. La maestra me dijo que estaba bajito [en lectura] pero no sé cómo hacerle. (Interview \#2) this." So they liked that I gave me the lottery and bingo because it gives them a hand. They don't know, they say "Teacher, I don't know how to do this. The teacher told me he is low [in reading] but I don't know what to do" (Interview \#2)

The second area with the highest unit of meanings for Diana was motivating students to read with eight units of meaning. She wanted her students to see reading as an activity with real life applications. When setting reading goals, students identified professions for the future and they discussed how reading would be a part of the work they would do. She wanted them to see themselves as professionals using biliteracy skills.

Gema. For Gema, language was the theme that had the highest number of units of meaning, appearing 28 times, followed by collaboration which appeared 18 times. Within the theme for language, additive view of bilingual education appeared in 18 units of meaning. She was a strong advocate for the rights of language minority students and their 
parents. She saw the use of Spanish in the classroom as a tool to elevate the status of the language among students. She mentioned how the Anglo community was embracing bilingual education and families who in the past had their children in English only classrooms were now choosing the dual language program. Gema came from Latin America and identified herself with her students, wanting to use her native language to support language minority students in their journey to bilingualism and biliteracy. She no longer wanted to teach in a different program if it didn't involve biliteracy:

Mi vida ha cambiado y ha crecido por biliteracy. O sea, para eso es para lo que yo me he preparado y me sigo preparando, para eso. Así de grande es. Si a mí me ofrecieran hacer otra cosa en educación, no lo tomaría. Yo creo que da tantas oportunidades a los niños y lo veo desde el punto de vida personal. Primero porque el idioma es parte de mí. Soy yo. Y esa es la razón por la que yo me convertí en maestra y no estoy haciendo [otra profesión]. Para usar mi lenguaje para ayudar a otros. (Interview \#3)
My life has changed and grown because of biliteracy. In other words, that is why I have prepared and continue to do so. It is huge. If I were offered another job in education, I wouldn't take it. I think you give so many opportunities to children and I see it from a personal point of view. First because language is part of me. It's who I am. And that is the reason why I became a teacher and I am not practicing [other profession]. So I could use my language and help others. (Interview \#3)

Sally. Sally had a similar number of units of meaning for all three themes.

Language had one more significant statement, appearing 18 times in the interviews.

However, the subcategories of collaboration with teachers and motivating students to read had the most units of meaning with 14 and 12, respectively. This is not surprising given that in her role as instructional coach Sally worked closely with teachers to improve student learning. She is skilled at assessing students and identifying areas for reading instruction; teachers recognized these skills. She used her reading endorsement applying her knowledge and skills coaching and working with teachers in their 
classrooms. In fact, according to Sally "most of the time in coaching they [teachers] want to focus on reading and specifically on diagnosing reading behaviors and prescribing what to do to move students forward" (Interview \#1). For her, coaching was a way to improve instruction and create systemic changes in the way teachers worked. Sally helped teachers develop their own assessment skills and identify strategies to work with students. According to her, there was not a magical book with recipes to fit readers who struggle into solution boxes. Consequently, teachers needed to consult research and resources and try strategies to address specific reading behaviors that needed attention. This was essential to being a reading specialist:

I try to help guide them [teachers] into how they can find that answer on their own, because really that is what the essence of being a reading specialist is, figuring out what is going on with this student and then what can I do to help close that gap and help fill that for him, so he can move on to a new focus. (Interview \#3)

\section{Synthesis of Findings}

Regardless of the area of emphasis shown by the frequencies in which each theme appeared for each participant, the end goal of all participants was to promote student learning. Development of biliteracy skills was key, whether this was achieved through collaborating with teachers or parents, or by creating engaging, enjoyable and effective learning conditions for readers who struggle. I discuss this below as part of a composite description that captures the essence of the understanding of the phenomenon of teaching biliteracy for all participants. 


\section{Composite Description}

The experiences shared by the participants in this study were captured in 201 pages of interview transcripts. The findings show that for bilingual reading specialists in this study, the themes of collaboration, language and caring were connected and crucial to support student biliteracy development.

The essence of being a bilingual reading specialist was to develop students' biliteracy skills in two languages, specifically English and Spanish in this study. This required participants to address two fronts, namely reading and language. In terms of reading, participants worked with a variety of students and ages at the elementary level, from beginning readers in primary classes to readers who struggle in all grades. Teaching took place in small reading intervention groups for reading specialists providing Title I services. In addition to working with small reading groups, participants also worked with the whole class in their roles as classroom teacher or instructional coach. In both cases, bilingual reading specialists had to pay close attention to students' reading behaviors and address their specific needs. It was important to not only pay attention to student reading skills but also to address their emotional needs and to cultivate a healthy self-image. For this, participants celebrated all student successes and created engaging and motivating learning activities. They wanted to instill in readers who struggle a sense of accomplishment and a love for reading. Bilingual reading specialists needed to have a keen eye to identify individual needs and to address them on the spot. This required them to have a flexible and organized structure in their teaching that would maximize the time they had with students. 
In terms of language, bilingual reading specialists were supportive of bilingual education. They saw biliteracy as an asset and were aware that Spanish needed to be developed strongly in school given the short time that students were receiving instruction in that language. Also, participants were aware of the power of English and wanted to elevate the status of Spanish in the classroom and in school. Bilingualism was seen as a right for native-Spanish and native-English speakers alike. It would prepare them well for the future in their local community and the global economy.

Developing strong biliteracy skills among students was a collaborative effort among teachers and parents. The school district influenced the implementation of bilingual programs through decisions about models and materials that were adopted. Participants would have liked to have more specific professional development in Spanish literacy. However, they worked together to answer questions particular to Spanish not addressed by monolingual consultants hired by the district. Participants were also resourceful and creative to use what they had with their students who were learning and developing two languages.

\section{Epoche and Its Role}

I wrote an Epoche before starting the interviews. According to Van Manen (1990) this would help make my beliefs, assumptions, understandings and preconceived ideas of the phenomenon explicit. It was important to be conscious about my assumptions so I could listen carefully to what participants were saying during the interviews and continue our conversation based on how they experienced the phenomenon of biliteracy. The Epoche (Appendix B) allowed me to compare my experiences to that of participants in 
some areas. Table 5 shows a comparison, in percentages, of how often the themes identified in this study were brought up by participants and appeared in my Epoche.

Because I do not have a reading endorsement and have not worked as reading specialist, I thought I could best relate my experiences teaching biliteracy to Gema's. However, I found some commonalities and differences with the experiences collected from the other participants as well.

Table 5

Participants and Researcher Thematic Comparison

\begin{tabular}{|c|c|c|}
\hline $\begin{array}{l}\text { Theme: } \\
\text { Subcategories }\end{array}$ & Participants & Researcher \\
\hline Collaboration & $35 \%$ & $25 \%$ \\
\hline Collaboration with teachers & $15 \%$ & $17 \%$ \\
\hline Collaboration with parents & $20 \%$ & $8 \%$ \\
\hline Language & $38 \%$ & $54 \%$ \\
\hline PD not in Spanish & $10 \%$ & $13 \%$ \\
\hline Materials \& time & $9 \%$ & $13 \%$ \\
\hline Additive view of BE & $19 \%$ & $29 \%$ \\
\hline Caring & $27 \%$ & $21 \%$ \\
\hline Engaging students to read & $10 \%$ & $17 \%$ \\
\hline Motivating students to read & $16 \%$ & $4 \%$ \\
\hline
\end{tabular}

This table compares the findings from the participants and the researcher's Epoche. 
The commonalities I found were in the area of language. My Epoche discussed how I did not receive specific courses at the university or professional development focused on Spanish literacy. I have felt frustrated about this fact and in part this was one of the motivations for this study. However, whereas participants discussed this issue, it was only one aspect of their experiences which was brought up in $10 \%$ of their significant statements. In terms of materials, I agreed with Marie about the need for better translations and more culturally relevant literature. The area of language in which my Epoche had the most commonalities with participants was in viewing bilingual education as additive. The participants and I saw how dual language programs benefited all students and how important it was to gain greater support from stakeholders statewide.

The major differences between my Epoche and what participants shared came in the area of collaboration and caring. I only mentioned collaboration with parents twice in my Epoche, representing $8 \%$ of my significant statements while participants brought up this theme in $20 \%$ of their significant statements. Participants discussed the theme of motivating students to read in $16 \%$ of their significant statements while I only included it 4\%. The importance participants gave to collaboration and caring aligned with their efforts to support students in their daily experiences with biliteracy in elementary school. I, on the other hand, have been working with pre-service teachers for the past eight years and I am more involved with professional development rather than in direct contact with parents or students.

For participants in the study, professional development is one of many tools they use in their work with students. Bilingual reading specialists spend all day working with 
students. Their main concern is student learning and to this effect they collaborate with other teachers and parents, create engaging environments for learning, and motivate students to read. Student learning is their primary focus. Their practice requires both the application of theoretical knowledge as well as the experience they gain working with individual students. They are constantly adapting the strategies they learn in English to use them in teaching literacy in Spanish and helping students acquire biliteracy skills. Professional development is only a part of what they do. Their practice is directly informed by their experiences working with elementary students.

In contrast, professional development for me is a main avenue for preparing teacher candidates. I spend all my time working with teacher candidates. My emphasis is on preparing them effectively to teach students. I spend a significant part of my time reading theory and research about teaching. I convey this theory, model strategies, and observe and supervise teacher candidates in the field. I view professional development as crucial since that is how I teach my students. While in my teaching I stress the need for culturally responsive pedagogy, I am not in direct contact with students and families in public schools. My work makes me focus on teacher candidates, who in turn work directly with parents and students.

Writing, reviewing and analyzing the Epoche helped me to have a fresh perspective and open mind toward the phenomenon under study. I tried to listen to participants carefully without trying to impose an agenda on them and analyzed the transcripts to capture the essence of their experiences. 


\section{Summary}

The findings in this chapter present the themes that emerged from the interviews conducted in this phenomenological study of bilingual reading specialists and their understanding of the phenomenon of teaching biliteracy to bilingual students. All participants worked at the same school district, either as a classroom teacher in a dual language class or as reading specialists or instructional coach, supporting students in bilingual programs.

The essence of teaching biliteracy was to develop successful readers in two languages. Participants wanted students to become lifelong readers who enjoy reading; to this effect they created supportive environments that targeted specific reading needs. Participants worked in collaboration with other teachers and parents to equip students with the necessary skills to become independent and successful readers in two languages.

Bilingual reading specialists supported bilingual education and saw bilingualism and biliteracy as an asset. They acknowledged the needs of the language minority student population in this district and were committed to their success in school. They also discussed how native-English students benefited from bilingual education. The theme of language identified in the findings was related to the school district's efforts for professional development, and decisions that affected the dual language program.

In the next section, I discuss the findings from this study through a critical pedagogy framework. I apply the knowledge gained from the participants' experiences about biliteracy to inform teacher educators, school district personnel, and state policy makers on how to support biliteracy pedagogy and teacher preparation in the state. 


\section{CHAPTER FIVE \\ DISCUSSION, RECOMMENDATIONS, AND \\ FUTURE RESEARCH}

This phenomenological study was situated within a critical pedagogy framework and aimed at exploring the lived experiences of Spanish-English bilingual reading specialists and how they understand the phenomenon of teaching biliteracy to bilingual students. The study analyzed the experiences of four bilingual reading specialists working at the elementary level in the same school district. Two of the participants worked as reading specialists, providing additional reading instruction to small reading groups. One participant was a classroom teacher in a two-way bilingual program and the last participant was an instructional coach at a two-way bilingual school. This study gave bilingual reading specialists an opportunity to share their experiences and thus voice their understanding of the phenomenon of teaching biliteracy.

The following sections guide the discussion as I present insights gained from the participants' experiences in an effort to help stakeholders in the state of Oregon consider the essence of biliteracy pedagogy and how to support the work of bilingual reading specialists:

- Findings and their connection to the literature

- Recommendations for stakeholders

- Recommendations for future research

- Limitations 
- Personal reflections

- Final thoughts.

\section{Findings and Their Connection to the Literature}

The previous chapter presented the findings from the interviews with participants. For the bilingual reading specialists in this study, the essence of teaching biliteracy was to develop successful readers in two languages. Participants wanted students to become lifelong readers who enjoy reading; to this effect they created supportive environments that targeted specific reading needs. Participants constantly assessed their students and worked in collaboration with other teachers and parents to equip students with the necessary skills to become independent and successful readers in two languages.

The literature discussed in chapter 2 focused on critical pedagogy and on teacher preparation. I identified connections for both of these areas through the experiences and understandings of biliteracy shared by the participants.

\section{Critical Pedagogy}

The experiences shared by participants in this study echoed beliefs and actions that critical educators take to promote social transformation in schools. The majority of connections between what participants shared and the literature came from critical pedagogy and the education of minority populations.

As a site for liberation for minority students, Wink (2005) posited that schools should frame the education of ELs to create the conditions for social justice, equality and empowerment. This transformative or liberatory education of language minorities includes the recognition and value of the students' native languages as assets (Flores 
et al., 2011; Macedo, 2000). It also provides the conditions necessary to empower minority students by respecting and dignifying their own histories and cultural traditions (Macedo et al., 2003). Figure 8 presents an overview of the role of schools, discussed in chapter 2, as either a place for liberation or domination (Freire, 2000; Macedo et al., 2003; Wink, 2005). From all the categories listed in the literature, data from this study is linked to the following categories in Figure 8: (a) dignify minority history and culture; (b) value native language; and (c) additive bilingualism.

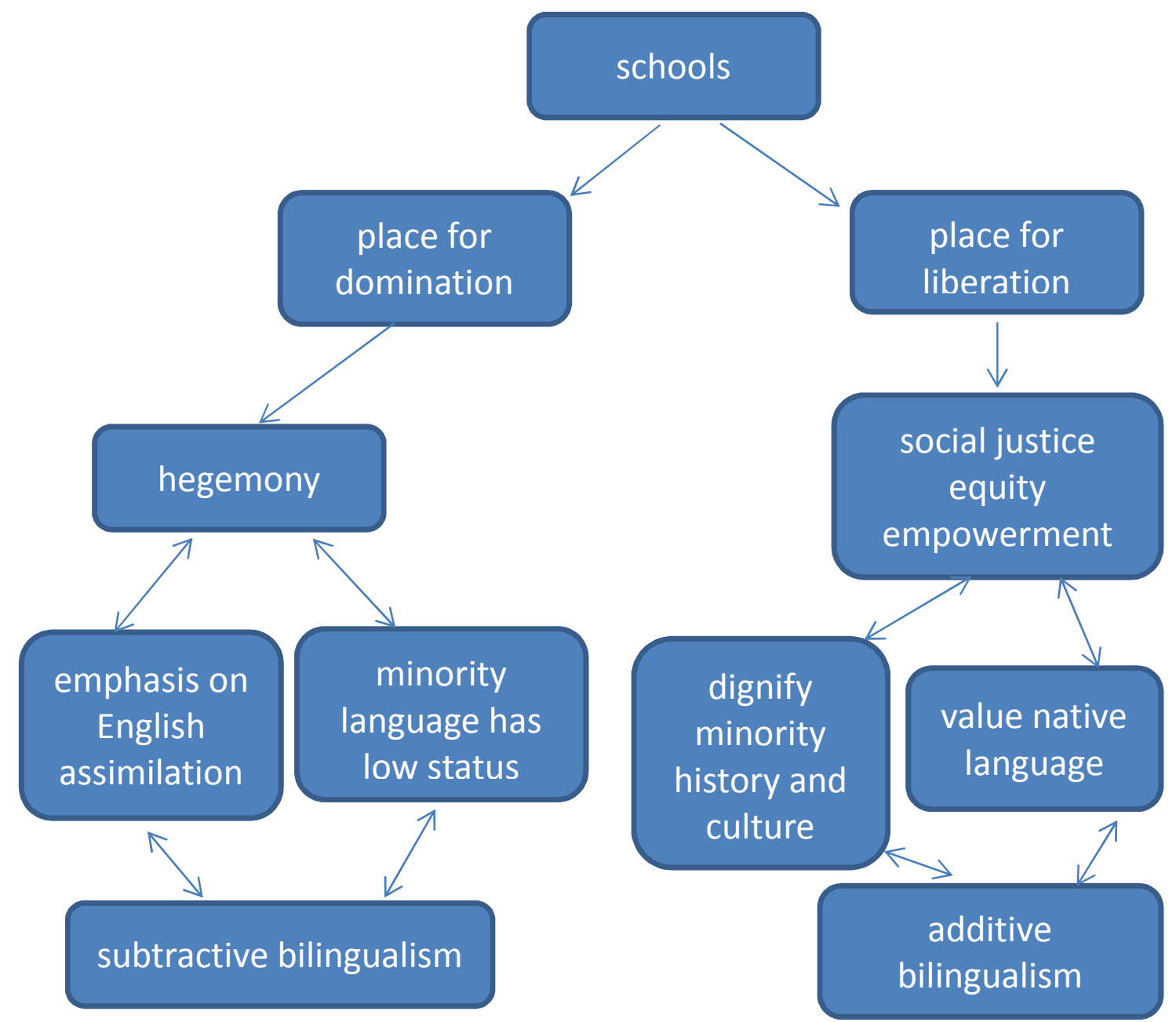

Figure 8. Critical pedagogy view of schools as either a place for liberation or domination. 
Dignifying minority history and culture. There were several instances in which Diana and Gema celebrated student culture in their teaching. They invited parents to participate in school events that valued and promoted the Hispanic culture (Wink, 2005). Diana invited parents to her dual language classroom; they shared their lives and experiences in Mexico with students. She enjoyed this collaboration: "Me gustaba mucho hacer trabajo con los papás, danzas, juegos o cosas que también los mismos papás se sintieran como valorados. Invitar a los papás para que vinieran y les enseñaran cosas” (I liked to work a lot with parents, dances, games or things that made parents feel valued. Invite parents so they would come and teach things [to the class]. Interview \#1). She recognized that some of her Hispanic students were second or third generation immigrants and wanted to increase their understanding of Mexican traditions. She also wanted her native-English speakers to encounter and learn more about culture in the language they were studying. Diana's students, now in high school, still remember their mariachi presentation and how their pictures were displayed on the district's website. Parents also became involved in the preparation of suits for the mariachi and enjoyed the celebration of Mother's Day, which Diana scheduled on May 10, following the Mexican calendar for that holiday.

Gema included stories, curriculum materials, and visuals in her classroom that represented Hispanic culture (Wink, 2005). However, a unique way in which she celebrated student culture was the creation of a dance group. Teachers and parents formed this group and performed traditional Mexican dances for students during a school 
assembly. Gema wanted teachers to learn and value their students' culture and she

wanted the students to see this:

Entonces mi propósito con el baile no solo es cultural sino didáctico de los dos lados. Que las maestras aprendan de la cultura de sus estudiantes, que respeten la cultura de sus estudiantes y que muestren a los niños que ELLAS [énfasis en ellas] están orgullosas de su cultura. Porque a veces nuestros niños lo pierden también. A veces nosotros no les mostramos, no tiene importancia para ellos porque con los papás lo escuchan todos los días, pero si ven a su maestra bailando su cultura y respetando su tradición, ellos quieren aprender, ellos quieren hacerlo. Y las maestras están mostrando respeto a los padres. Esa es la idea del baile, no solamente bailar. Y por eso es que nuestro grupo está formado por maestros y padres. (Entrevista \#1)
My purpose with the dance was not only cultural but also didactic for both sides. I wanted teachers to learn from students' culture, that they respect their students' culture and show children that THEY [emphasis in they] are proud of their culture. Because sometimes our kids lose it also. Sometimes we don't show it to them, it is not important for them because they hear it every day from their parents, but if they see their teacher dancing their culture and respecting their tradition, they want to learn, they want to do it. And teachers are showing respect to parents. That is the idea for the dance, not only dancing. And that is why our group is formed by teachers and parents. (Interview \#1)

While Marie and Sally were careful to include books and resources that reflected their Hispanic students' culture, they also had a personal connection to the Hispanic culture. They both studied Spanish in college and had traveled to Latin America. They embraced their students' culture and it was now part of their own lives. Sally married into a Hispanic family and was raising her daughters to become bilingual and bicultural. While she found instruction in Spanish challenging at first, she was always interested in her students' culture:

I loved the challenge, obviously, but more than that, I really love the kids. I loved the culture. My experience with bilingual education has been almost purely Spanish, or Spanish-speaking, a lot of people from Mexico and El Salvador ... I love people and learning about different things, different lifestyles. I don't know, it is hard to explain, but I just felt like I really related with them. I don't have that 
same background, but it spoke to me. I ultimately married into the Hispanic culture. My family is Salvadorian and I feel like I fit in really well with them. I just understand them and I wanted to be around more people that came from that culture. (Interview \#1)

Marie liked the daily cultural immersion she had in Spanish without having to travel

overseas. She was excited to teach in this culturally diverse district.

The job was very exciting to me because I was going to get to come to [city] and it was kind of like going to Mexico every day. That's what it felt like and that is why I was really excited. It made me feel good because I just knew that when I came here, it was going to be a cultural experience for me to come here every day. (Interview \#2)

All participants made an effort to include culturally responsive practices in their teaching, incorporating student culture into the curriculum. They viewed bilingualism as an asset and valued the students' first language.

Valuing native language. Participants valued Spanish and viewed it as an asset. They talked about different ways in which they valued their minority students' language in the classroom and promoted it outside the classroom as well. In the case of two-way bilingual programs, ELs' native languages are seen as valuable, as they serve as linguistic models for native-English speakers who learn the non-English language (Cloud et al., 2000; Diaz-Rico \& Weed, 2010; Freeman et al., 2005).

This is exactly what Gema was able to accomplish. As a classroom teacher, she worked with native-Spanish speakers and native-English speakers who learned side-byside. When she first started teaching in this district she noticed that her native-Spanish speakers did not feel as confident talking because they did not speak English. However, Gema was able to change this deficit perspective (Bruner, 1996) and had the nativeSpanish speakers teach Spanish to the native-English speakers. This boosted the students' 
self-esteem and the value they placed on their native language: "Mis chiquitos que antes estaban así, que no querían ni hablar porque no hablaban inglés, ahora se pueden explayar y decir y enseñar a los otros." (Entrevista \#3). (My little ones who were like this before, who did not want to talk because they did not speak English, now can say and expand and teach to the others [native-English speaking children] Interview \#3). Gema's decision to purposefully elevate Spanish language in her classroom demonstrated her convictions and commitment to use the instructional context and change the power of languages. She recognized that school programs are mainly designed to support English acquisition and made a concerted effort to change this in her classroom by placing an additive value to Spanish. Minority language students had a purpose for using their native language and the status of Spanish (Macedo et al., 2003) was elevated in this classroom:

Yo les digo a mis niños [hispanos], a I tell my [Hispanic] kids, "now you go ver "ahora tú le vas a enseñar a él cómo se dice [eso], ahora tú le vas a mostrar y tú le vas a platicar." Entonces ya cambió, ya el inglés no está en poder sobre el español. Por lo menos en estas clases es igual o el español está dominando. (\#3) and teach him how to say [this], now you will show him and talk to him." Thus this is changing, English is not in power over Spanish. At least in these classes is equal [to Spanish] or Spanish is dominating. (Interview \#3)

Gema also tried to promote the use of Spanish outside the classroom. She wanted to see Spanish used as a professional language in the school. Her school has agreed to promote the use of Spanish as a professional language outside the classroom. Her principal had already asked her to correspond with him in Spanish so he could practice Spanish and improve it. There was a conscious effort to elevate the status of Spanish and a delicate balance to not outcast those who were not bilingual. 
Hemos hablado de la igualdad y que si realmente estás enseñando el idioma [español] tienes que promoverlo, dentro y fuera de la clase y profesionalmente. ¿Cómo vas a enseñar dentro de la clase y sales y se olvidó el español y puro inglés? Ya el inglés es el idioma dominante. Ha sido aceptado aquí [en la escuela] de que sí, vamos a usar el idioma dentro y fuera. Y pues, por supuesto que eres profesional $\mathrm{y}$, cuando hay personas que no lo hablan, no. (Interview \#2)
He have talked about equality and that we are really teaching the [Spanish] language you have to promote it, inside and outside the classroom and professionally. How can you teach inside the class and then forget Spanish and [use] only English? English is already the dominant language. It has been accepted here [the school] that we are going to use the language inside and outside. And, of course you are professional and, when there are people who don't speak it, no. (Interview \#2)

Diana has also implemented school-wide activities to value and promote students' native languages at school. Along with the other reading specialists in her school, they created "El Día del Idioma" (Language Day) and had a writing contest. They chose April 23 to celebrate a language day and have linked famous authors from each of the languages represented at school to this month.

Another thing that is important to note here is that this school district offered bilingual education through high school. The Anglo community has embraced bilingual education and was enrolling their students in dual language programs. Gema talked about a family who formerly enrolled her children in English-only classes but now had the youngest child in her classroom learning Spanish. According to her, the family had seen the advantages of bilingual education in other students and now wanted her child to benefit from biliteracy. Diana also mentioned the interest of Anglo families in dual language programs and talked about how the transparency of Spanish as a phonetic language (Arteagoitia, Howard, Loguit, Melabonaga, \& Keyton, 2005; Genesee, Geva, Dressler, \& Kamil (2008) made it easier for Spanish-Speaking students to learn to read. 
The value of minority languages was also clear in Marie's perception and treatment of student spelling errors in English. Marie had developed a good understanding for literacy development and was able to identify mistakes commonly made by native-Spanish speakers as normal and transitory. She was able to focus on the meaning of the stories written by ELs and was not bothered or distracted by their inventive spelling. Having worked with Spanish-speaking students for a long time, she was used to seeing developmental errors in Spanish. One summer, Marie worked at a migrant school program alongside other reading specialists. She was surprised by how the monolingual English reading specialists with whom she was working treated the student spelling errors.

There are definitely mistakes you see with kids learning-if they are Spanish readers and they are writing in English, they will make very particular mistakes. When I was in the summer program, the teachers saw that this kid had written "the" with a " $d$." They were like, "I can't believe he did that." But that is one of the mistakes that Spanish speakers will make when they are writing in English. The $d$ they think is a th. That sound sounds like a $d$. (Interview \#3)

There were several other examples in which the minority students' language was valued. Furthermore, in multiple occasions, participants referred to biliteracy and bilingual education as additive.

Additive bilingualism. Participants in this study saw Spanish as a resource and asset, and wanted their students to develop biliteracy skills in Spanish and English. Participants were aware that minority-language students needed to develop strong English skills to succeed in school and in their future careers in the United States. They were also aware of the influence and status of English in the country (Macedo et al., 
2003). Furthermore, participants were careful not to develop English skills at the expense of students' first language.

Gema shared how when she first started teaching in this district, she was concerned about developing native-Spanish speaker students' English skills at the expense of Spanish because the bilingual program placed a lot of emphasis in English.

She remembered:

Había mucho énfasis hacia el inglés aunque le llamaban programa bilinguie. Siempre pues era el idioma que tenía más poder y que estos niños tenían que transferir al otro idioma. Entonces tenía que aprender cómo hacerlo correctamente sin que perdieran el suyo. Yo creo que eso era más mi temor de que crecieran sin quitar [pausa] y creciendo lo que ellos ya tenían. (Entrevista \#1)
There was a lot of emphasis toward English, even though it was called a bilingual program. This was, after all, the language that had more power and these kids had to transfer to the other language. I had to learn how to do it correctly so they would not lose their language. I was apprehensive about developing [English] without taking away [Spanish]; and to continue developing what they already had. (Interview \#1)

For participants it was important to develop strong academic Spanish skills that would enhance the acquisition of strong academic English skills among their nativeSpanish language students. Participants also discussed how important it was that nativeEnglish speakers learn two languages and benefit from biliteracy skills. They had seen how the Anglo community at the school district was embracing bilingual education and saw this as an opportunity to value diversity and embrace the minority language and culture (Freeman et al., 2005; Lindholm-Leary, 2004). In fact, bilingual reading specialists mentioned how they would like to see bilingual education supported by stakeholders and how all students benefited from it. Gema put it this way: 
Biliteracy es una necesidad no solamente para los niños que hablan español, para todo mundo. Porque el mundo está cambiado pero más que nada es por la riqueza porque los niños, es la riqueza de la educación ... Tienen todos los derechos de aprender, tienen todo el derecho de aprender en su idioma y los niños que no hablan el idioma tienen todo el derecho de aprenderlo. Todos los países del mundo hablan más de un idioma, excepto aquí casi. Entonces es una necesidad, es una realidad y es un derecho de los estudiantes. (Interview \#3)
Biliteracy is a need, not only for children who speak Spanish but for everyone. Because the world is changing but more than anything is a richness because of the children, is the richness of education ... They all have the right to learn, they have the right to learn in their language and the children who don't speak the language have all the right to learn it. All countries in the world speak more than one language, except here almost. Then it is a need, it is a reality and a right for all the students.

(Interview \#3)

While participants embraced additive bilingualism and discussed their efforts to

develop literacy skills in two languages among students, they faced program challenges (discussed under the theme of language in chapter 4). One of those challenges was the lack of professional development in Spanish (Escamilla, 2006). In the next section, I discuss this issue and other issues relevant to the literature review regarding teacher preparation.

\section{Teacher Preparation}

The experiences shared by participants in this study echoed those shared by teachers in Escamilla's (2006) study regarding the lack of specific professional development in Spanish. Escamilla pointed out that, in the United States, professional development relied on using literacy, assessment strategies and methods researched in monolingual English-speaking populations with bilingual students.

Subtractive bilingualism frames teacher preparation. In the majority of states in the United States teacher preparation programs only address instruction for English 
literacy development (Fitzgerald, 2000; Rios \& Van Olphen, 2011). With the exception of Diana, who studied education in her home country, bilingual reading specialists in this study had received limited professional development or courses on how to teach biliteracy. None of the participants had received specific courses for teaching Spanish literacy in their teaching preparation programs. However, they learned strategies to support English development as part of their ESOL reading endorsement programs. The courses and pedagogy covered at the university level emphasized instruction in English. This reflected national trends in teaching preparation programs where the emphasis was on transitioning ELs to English-only instruction (Fitzgerald, 2000, Rios \& Van Olphen, 2011). Blum Martinez and Baker (2010) discussed the gap that bilingual teachers experienced during their teacher preparation programs in regards to biliteracy pedagogy. Despite having one student teaching practicum in a bilingual classroom, Sally recalls that in college she covered general information about bilingual education:

We talked about more generic [strategies], like some of the basics, like differentiating instruction, how you can use reality to help English language learners. They are kind of cliché in bilingual education, but all the things that you can do to help English language learners. The goal was to learn English. It wasn't so much around biliteracy. Really, I don't remember there being any focus around biliteracy in college. (Intervew \#1)

However, participants in this study received courses in Spanish during their reading endorsement program. They recalled the information covered in these courses differently. While two participants mentioned that the strategies they learned were general, another participant valued the opportunities these courses provided to collaborate with other bilingual teachers. Yet another participant did not remember specifics about the courses taught in Spanish but that she had read Paulo Freire's work on literacy. 
Professional development is not focused on Spanish literacy. While all

bilingual reading specialists valued the professional development they received in literacy, they also acknowledged how it was not specific to teaching literacy in Spanish.

One of the participants shared her frustration and used an analogy about the need to transfer what she learned to Spanish literacy instruction:

Well, I am frustrated, because I really want to learn more about how to really develop Spanish reading abilities. I feel like I've learned on my own through trial and error. I've learned ways to teach kids to read in Spanish and obviously I am able to do it because I do it. But I don't know, I would be frustrated if I was a math teacher and all I ever did was go to science seminars and never, ever, actually looked at math. I kind of feel like how that it is a little bit, because I am supposed to be teaching Spanish reading, but yet I'm never actually given any PD [professional development] actually on that. It is always just reading instruction. I can transfer a lot of what we do, I can, but I think it would be more powerful if it were presented to us in Spanish, if we had an opportunity to discuss out students' reading and the kind of things they are doing during Spanish time with each other. (Interview \#3)

Escamilla (2006) pointed out that pedagogical strategies and methods used with monolingual populations were perceived as "good teaching" and applied to teaching Spanish literacy to Spanish-English bilingual students in bilingual programs in the United States. This seemed to be the case for what participants in this study experienced when they received professional development in literacy within their school district.

\section{Critical pedagogy approach to bilingual teacher preparation. Díaz-Soto}

(2011) emphasized how critical pedagogy makes educators aware of issues of power and the constant decisions they make concerning social justice issues. Participants in this study, specifically Gema and Diana, were aware of the status English had and how minority students and families viewed school (Macedo et al., 2003). I discussed earlier the efforts that Gema and other bilingual reading specialist did to elevate the status of 
Spanish and how they valued minority language and culture as an asset. In this section, I discuss how the collaboration bilingual reading specialists had with teachers and parents reflected the praxis component of the critical pedagogy model that Flores et al. (2011) presented in their framework for preparing bilingual teachers.

Sociocultural learning theory. Learning is influenced by social, cultural and political factors that influence how individuals interpret reality and interact with one another (Bruner, 1996). Learning both as a mental activity and a process needs to take into account the cultural setting and resources where learning takes place. Flores et al. (2011) emphasized the importance of "critical connections among the social, language, and cultural dimensions of learning" (p. 17) pre-service teachers make in order to coconstruct new knowledge, contextualize instruction and enhance their practice.

Participants in this study were teaching in the same school district and collaborated with other teachers to learn strategies to teach biliteracy as well as to support student learning. It was through collaboration that participants learned how to teach literacy in Spanish from and with their colleagues. Vygotsky (1978) suggested that learning is socially mediated. He said that social interactions support cognitive development. Vygotsky's emphasis on learning as a social process gives relevance to the collaboration participants experienced and valued as a means to support and enhance their teaching practices. Furthermore, it also supports the leadership role the IRA (2010; Kern, 2011) encourages reading specialists to have as experts in their field. Bilingual reading specialists mentored and guided other teachers who worked with emergent readers and readers who struggle. 
For instance, Marie collaborated with classroom teachers and helped them identify appropriate reading materials for students:

... a fourth grade teacher might have one student that is reading at a level of first grade or barely started to read yet and don't know what to do. Then I try to support them by getting them the right books to use with those kids and showing them different things that they could use, like letter charts. (Interview \#3)

For Flores et al. (2011), sociocultural learning theory would help prepare teachers to develop competencies such as acknowledging connections between their practice and their environment. It would also help teacher candidates to co-construct new knowledge and to contextualize instruction in their particular settings and conditions. This seemed to be what participants were doing as they were translating strategies and research for English literacy into their own teaching when working with bilingual students in Spanish. Marie's adaptation of Reading Recovery techniques, learned through collaboration, into Spanish reading instruction demonstrated these competencies:

I was learning some things from the people I worked with, because I worked with C.C, she is trained in reading recovery. She had some things that she was doing, which I incorporated them into Spanish. She was doing them in English but I tried to incorporate that into what I was doing with Spanish, because it was a little different because I was using syllables instead of using letters. She would use the Elkonin boxes and sounding out words. (Interview \#1)

Sociocultural learning theory views learning as a social process. It is important then to highlight the significance of collaboration between school and families. The collaboration with parents that participants discussed during the interviews could be examined through the lenses of cultural competence and culturally responsive teaching.

Cultural competency. Flores et al.'s (2011) model for preparing bilingual teachers views cultural competency as having both a personal and professional level. At the 
personal level teacher candidates recognize and respect their own culture and language; at the professional level they conceptualize the role of culture and language and incorporate it into teaching. They use and include "linguistic traditions, cultural practices, ethnic rituals and community resources to enrich the learning experience of students" (p. 17). Participants in this study viewed parents and families as an important resource in the development of biliteracy skills. They collaborated with parents in several ways inside and outside the school setting.

Participants valued parents' contribution in the learning process and sought different avenues for collaboration. Marie, for instance, would send books home for parents to read to students. This supported a reading environment at home and motivated students to read. Sally talked to parents about ways in which they could support readers who struggle at home. Diana met with parents individually and provided them with specific tools to support literacy development at home. Participants also hosted literacy nights at school for parents and students. In these interactions, bilingual reading specialists took the role as experts as they shared with parents different ways to support biliteracy development at home. In other cases, participants recognized parents as the experts and invited them into their classrooms to share their experiences and teach students about their culture. This provided an opportunity to validate the parents' cultures as a resource for the classroom; students learned about linguistic traditions and cultural practices. Furthermore, Gema collaborated with parents and teachers and used the dance group not only as a tool for cultural transmission but also as a tool for social transformation. 
Gema's use of the dance group as a tool for social transformation requires closer analysis. She was aware of the status of English as the language of power (Macedo et al., 2003) and how Hispanic families viewed school (Valdés, 1996). She talked about how in small villages in Mexico the priest and the school teacher are seen as authority figures. By bringing parents and teachers together in the dance group, she provided an opportunity for both groups to get to know each other and to develop a relationship where both parties were equals. Teachers and parents were learning to dance and neither one was seen as expert. This helped parents become more comfortable coming to school and approaching teachers. Teachers were able to learn more about the parents' culture and about their students. Gema did this intentionally:

Lo del baile inició por ahí para traer a los papás y a los maestros al mismo nivel. Y el año pasado tuvimos once mamás bailando con catorce maestros. Es algo bien poderoso porque los niños lo ven, que tu mamá está bailando con las maestras, y también los padres podemos hacer cosas juntos. Nadie está más arriba de nadie, todos tenemos que aprender. Yo tengo tanto que aprender de ellos como ellos tienen que aprender de nosotros. No que tienen pero tenemos mucho para dar. Pero al mismo tiempo ellos [padres] son mi fuente de información para yo poder trabajar aquí. (Interview \#1)
The dance [group] started to bring parents and teachers at the same level. Last year we had 11 mothers dancing with 14 teachers. It is something powerful because the children see it, your mom is dancing with the teachers, and parents can do things together. No one is higher than anybody, we all have to learn. I have as much to learn from them as they can learn from us. It is not about them having but all of us having a lot to share. At the same time they [parents] are my source of information so I can work here. (Interview \#1)

Gema had a strong understanding of how parents viewed school and what she could do to make them feel welcomed (Valdés, 1996). For her, it was equally important that parents felt comfortable in the school setting and that teachers had an opportunity to learn about the students' cultures. She thought that teachers would value and show 
respect toward their minority culture. Moreover, minority students would feel pride seeing their traditions and cultural heritage honored at school. As discussed earlier, this was one way in which she dignified students' culture.

According to Wink (2005) school-family relationships and activities are normally framed within transmission models. Teachers and schools own the knowledge; parents attend meetings and learn from teachers. Wink posits that a transformational approach to parent involvement would view families, students and teachers as owners of knowledge and families and teachers would learn together. The collaboration between teachers and parents in this study falls along a continuum of transmission to transformational interactions. I am placing the activities where parents were invited to learn about literacy activities in the traditional end of the continuum. The activities where parents came to share about their culture in the classroom fall in the middle of the continuum, between traditional and transformative approaches. Gema's dance group falls in the transformational end of the continuum. She taught parents and teachers traditional Mexican dances which they presented at a school assembly. This dance group aimed not only at sharing traditional dances but at changing the interaction among teachers and parents. She used the group dance as an equalizer in the relationships between these two groups. She allowed parents to feel more comfortable with teachers and teachers to value and learn from students' culture. Figure 9 shows how the different collaborative activities between teachers and parents fall along the continuum of parental involvement I adapted from Wink's (2005) work. 


\section{Traditional}

Communication
with parents
follows traditional
norms
Requesting parent
presence during
school activities
with students
Inviting parents to
support own
student at home

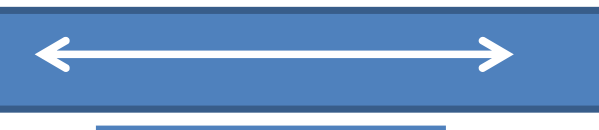

Transformative

Communication
with parents
follows culturally
relevant norms
Valuing parents'
culture and
language
Inviting parents to
support student
learning in the
classroom

Communication with parents follows culturally relevant norms

Valuing parents' culture and language

Inviting parents to change the perception and value of minority culture at school

Figure 9. Collaborative activities with parents. This figure represents participants' collaboration views with parents along a parental involvement continuum adapted from Wink's work (2005).

The cultural competency teachers demonstrated in their collaboration with parents, represented in Figure 9, evidences the complex nature of collaboration with parents that goes much deeper than parents volunteering in the classroom. Participants in this study saw their role in teaching as interconnected with parents. They saw school as an extension of the home in the education and upbringing of children. Furthermore, the better participants understood the culture of students and parents (Valdés, 1996), more activities fell under the transformative end of the critical pedagogy continuum for schoolparental relationships (Wink, 2005).

Along the continuum of parent collaboration, Gema was the only participant on the transformative end of the continuum. She saw parents as equal partners in the education of children and deliberately used a dance group to bring parents and teachers 
together as equals. She wanted her Hispanic students to see their culture valued at school and to see their parents working alongside teachers. For teachers, she thought that learning traditional Mexican dances with parents provided an opportunity to get to know parents better and moved them away from the expert role. For parents, this opportunity allowed them to not view teachers as an authority figure and to feel more comfortable coming to school.

Gema saw herself as a bridge for communication between the school and parents: "Yo me siento como un puente entre los padres y la escuela. Yo siento que ese es mi trabajo aqui" (I feel like a bridge between parents and school. I feel that is my work here. Interview \#1). She acknowledged that schools and families made assumptions about each other and about their role in students' education (Valdés, 1996). Understanding where parents came from and how they viewed school allowed her to purposefully address cultural differences between parents and teacher expectations regarding school-parents relationships through the dance group she created.

In this sense, Gema was taking a leadership role in the school by bridging communication between parents and teachers. She also took up the role of cultural ambassador, showcasing traditional Mexican dances. She wanted minority students to feel proud of their identity. She also wanted the Anglo students to understand, embrace and learn traditions from the minority students along whom they were learning Spanish in the dual language classes.

Preparation of bilingual reading specialists. Participants experienced and embraced the teacher leader or expert teacher role for reading specialists highlighted by 
the Standards for Reading Professionals (IRA, 2010). They were aware of their expertise and put it to the service of their colleagues and students. Participants guided or coached teachers who needed support working with readers who struggle, both formally and informally (Kern, 2011). They were often approached by teachers who recognized their expertise and sought their help. Other times, the principals assigned them to work with a grade level team or individual teachers. In addition, bilingual reading specialists were part of student intervention teams and prepared reports on the progress of their students. They also suggested strategies and interventions for students who were referred to the student intervention team.

As an expert teacher, Gema often shared her ideas and literacy strategies with her grade level team in an effort to benefit all students in her grade level. She felt a professional responsibility to utilize her expertise as a bilingual reading specialist in her daily work with students and teachers. Gema felt confident about the knowledge and skills she acquired with the reading endorsement. The endorsement not only broadened what she knew about teaching but also empowered her to feel confident about her own practices and instructional decisions. She viewed herself as more than a bilingual teacher:

Ahora sé que soy más que maestra bilingüe, puedo enseñar otras cosas, otras estrategias, tengo el conocimiento que estoy respaldada por algo que sí existe porque a veces piensas, ¿está bien lo que estoy haciendo? ... el reading endorsement me dio una valoración, me dio recursos, me dio investigación de que sí, estoy haciendo lo que debo hacer ... Y eso viene del conocimiento que he tenido, no se me hubiese ocurrido antes. Pero ahora sé
I now know that I am more than a bilingual teacher, I can teach other things, other strategies, I have the knowledge that I am backed by something that indeed exists. Sometimes you wonder if what your are doing is good ... the reading endorsement validated me, it gave me resources, it gave me research that confirmed that I am doing what I am supposed to do ... And that comes from the knowledge that I have had, I 
que lo podemos hacer, porque tengo el conocimiento o porque lo he escuchado o porque lo aprendí o porque es una extensión de lo aprendido. (Entrevista \#3) would have not thought about it before. But now I know that we can do it because I have the knowledge or have heard it, or because I learned it or it is an extension of what I have learned. (Interview \#3)

The other participants also felt empowered and comfortable in their role as teacher leader or expert teacher. However, participants recognized that they were still learning how to teach biliteracy and were not experts in biliteracy. They longed for specific professional development in Spanish literacy and biliteracy. Sally captured the sentiment shared by participants; she wished there were more research and experts in the field to inform her biliteracy teaching:

I just wish we had more training about how to really do it [teach literacy in Spanish]. We are just kind of doing it. We are building the ship as we sail, and some of us are better at that than others, but it is kind a bummer that there is not more out there that we could draw from. (Interview \#1)

Researchers and advocates in the field of bilingual education have voiced the need for specific professional development and research in biliteracy in the United States (Blum Martinez \& Baker, 2010; Escamilla, Ruiz-Figueroa et al., 2010; Flores et al., 2011; Goldenberg et al., in press; Hedgcock, 2005). Instruction in Spanish in the U.S. continues to be influenced by trends in English literacy research and instruction (Escamilla, Hopewell et al., 2014; Goldenberg et al., in press). This influence reflects the English hegemony prevalent in U. S. education (Macedo et al., 2003). Unfortunately, Anglocentric literacy views and practices (Johnson, 2013) applied to Spanish-English biliteracy instruction leave bilingual reading specialists without strategies, skills, or knowledge specific to Spanish literacy instruction. For instance, Sally mentioned how 
when analyzing a running record in Spanish (Andrade, Basurto, Ruiz, Clay \& Escamilla, 1996), bilingual teachers did not know how to mark the errors:

For years and years, there are still simple things that have never, ever been answered. Like in English reading, when we are doing running records, for example, we pretty much always know what is an error and what is not an error when they [students] are reading. It gets brought up all the time about, for example, when they say, N., is that going to be counted as an error or not? We go back and forth and different people have very strong opinions. There is no person who is the expert who is coming in to tell us whether or not those things count. We do a lot of research. We look into it as much as we can. We find the English equivalent of what that kind of question is and try and get that answer from that perspective, but... (Interview \#3)

Participants' experiences confirmed the need for professional development in the area of biliteracy instruction discussed in chapter 2. It seems that teacher preparation programs do not recognize the importance of biliteracy and continue to frame literacy instruction without acknowledging the role of language in literacy development. That is, Spanish skills and language characteristics get insufficient attention in the preparation of bilingual teachers and bilingual reading specialists. This is not surprising, given that while the Standards for Reading Professionals (IRA, 2010) recognize the need for literacy curriculum and instruction to be appropriately adapted to meet the needs of ELs they do not explicitly address support in the student's native language or for biliteracy development. Furthermore, even though teacher preparation researchers (DarlingHammond, 2006; Darling-Hammond \& Bransford, 2005; Gay, 2000; Gay \& Howard, 2000) stress the need for $21^{\text {st }}$ century teachers to be prepared to work with culturally and linguistically diverse students entering P-12 school, only researchers in the field of bilingual education advocate for language considerations in the preparation of bilingual 
teachers (Blum Martinez \& Baker, 2010; Escamilla, Hopewell et al., 2014; Flores et al., 2011; Goldenberg et al., in press; Guerrero \& Valadez, 2011).

Bilingual reading specialists would benefit from further understanding and research on the specific needs and differences in literacy development among bilingual learners in the United States (Goldenberg et al., in press). Goldenberg et al. cautioned researchers and practitioners about "applying psycholinguistic instructional principles across languages without taking into account potentially relevant differences in linguistic and orthographic characteristics" (p. 32). Their research found that phonemic awareness in Spanish was not necessary for early literacy instruction in Spanish and that teaching students to recognize and form syllables with letters and sounds was sufficient. Moreover, Escamilla, Hopewell et al. (2014) "reject the notion that 'good teaching is good teaching' and instead suggest that school leaders work closely with teachers to help them design and deliver comprehensive biliteracy instruction that is coherent and coordinated across languages" (p. 12). In order to better prepare bilingual reading specialists, teacher preparation programs need to address how differences between languages must be reflected in literacy instruction (Blum Martinez \& Baker, 2010).

The focus of this study was Spanish-English biliteracy. Phenomenology was chosen to offer insights from bilingual reading specialists that could bring teacher educators in more direct contact with their experiences and world (Van Manen, 1990). By gaining insightful descriptions from bilingual reading specialists, teacher preparation programs could address their needs and better prepare them to effectively do their job. Although the participants taught in English-Spanish bilingual programs, I believe that the 
findings from this study could reflect the experiences and understandings of bilingual teachers and reading specialists who work in other languages besides Spanish and English.

As discussed in chapter 2, the preparation of reading specialists is currently influenced by subtractive views of bilingualism and influenced by English hegemonic policies and instructional practices. These policies influence the macro and micro aspects of biliteracy instruction in the United States. Nonetheless, there are several actions that stakeholders (policy makers, school administrators, and teacher preparation programs) in Oregon could take to counteract the effects of subtractive practices and support the work of bilingual reading specialists. In the next section, I offer recommendations for stakeholders based on the experiences of the bilingual reading specialists who participated in this study. These recommendations aim at improving the way teacher educators prepare bilingual teachers and bilingual reading specialists in Oregon.

\section{Recommendations for Stakeholders}

The ODE (2013a) has recognized the increase in racial and cultural diversity as well as the increase of ELs in P-20 settings in the state and wants to address the needs of these populations who experience an educational gap compared to Caucasian students. The Oregon Education Investment Board (OEIB) stated in the Equity Lens vision statement (2013a) that speaking a language other than English constitutes an asset and that schools "must celebrate and enhance this ability alongside appropriate culturally responsive support for English as a second language" (p. 2). Moreover, as part of Oregon's Strategic Initiatives, ODE launched a Dual-Language/Two-Way Bilingual 
Grant intended for school districts to design, implement or improve dual language/twoway bilingual programs that will assist students in becoming academically proficient in two languages. This initiative to support additive bilingual programs and OEIB's recognition that teachers are one of the most powerful influences in student learning create momentum for advancing the preparation of bilingual teachers and reading specialists in the state.

Stakeholders in the preparation of bilingual teachers and reading specialists must first embrace language as an asset. In addition, besides focusing on culturally responsive instruction that supports English acquisition, stakeholders need to prepare teachers for biliteracy instruction that recognizes language characteristics and is not solely based on English research and pedagogy (Escamilla, Hopewell et al., 2014; Goldenberg et al., 2014). Below are my recommendations for policy makers, teacher preparation programs and school district administrators to work collaboratively and effectively in this effort. The recommendations specifically address the preparation of Spanish-English bilingual teachers and reading specialist. However, they could be applied for other bilingual teachers in other languages as well, if the references to Spanish were changed to the other target languages.

\section{Policy Makers}

Oregon English Learners Statewide Strategic Plan for 2013-2016 (ODE, 2013b) identifies eight goals to serve EL students in the state using research informed practices and models. Goal seven, in particular, focuses on providing "all educators the knowledge and skills they need in their positions to better serve English learners" (p. 20). 
Furthermore, objective three under this goal aims at increasing the number of licensed bilingual teachers in the state. The strategic plan calls for collaboration among policy makers, school administrators and Educator Preparation Programs (EPP) to serve the needs of ELs in the state. My recommendations for policy makers focuses on narrowing the objectives presented in this plan to address the preparation of bilingual teachers and reading specialists as well as the professional development efforts in the area of biliteracy for the state.

Department of Education. The following recommendations, even though they are numbered, are not listed in order of importance or priority:

1. Increase the number of presentations related to bilingual education and biliteracy at the annual English Learner Conference organized by ODE and the Confederation of Oregon School Administrators (COSA).

2. Fund research at the state level that either extends current research in biliteracy or develops new studies with a focus on biliteracy development for native-Spanish and native-English speakers in dual language programs.

3. Identify experts in the field of biliteracy in the state and invited them to be part of the EL work group.

4. Make sure the Network of Quality Teaching and Learning has a representation of educators knowledgeable in biliteracy.

5. Include in the "resource repository" a section on biliteracy and literacy instruction in Spanish.

6. Assign the person in charge of the repository to create periodic newsletters with research updates and relevant links to biliteracy pedagogy to distribute to administrators and bilingual educators.

7. Develop a plan for bilingual staff that addresses professional development needs in biliteracy.

8. Support collaboration between school districts and EPP that involves teachers, administrators and EPP faculty learning together about biliteracy.

9. Advertise and promote the teacher exchange program with Spanish speaking countries to increase the participation of Oregon teachers visiting Spanish 
speaking schools. This exchange would help native-English bilingual teachers increase their linguistic competence in Spanish and gain more insight about Hispanic culture and the school system in that country.

TSPC. On March 6, 2014, the Oregon's TSPC approved the proposal for Dual Language Immersion Competencies to create a specialty for Dual Language Immersion (K. Menk, personal communication, March 7, 2014).

The timing of this specialty is critical for the state given that the Oregon English Learners Statewide Strategic Plan for 2013-2016 (ODE, 2013b) aims, among other things, to (a) build bilingual capacity among staff across the state and (b) retain bilingual staff by "building proper skills through two-way evaluation" (p. 27). Furthermore, school districts in Oregon are creating dual language programs in response to the increasing number of native-Spanish speakers (or students speaking other languages besides English, such as Russian) entering elementary schools, and the Anglo community is slowly embracing dual language programs as additive models. As of January 2014, 70 elementary schools-out of 727 elementary schools-in Oregon were providing native language support up to certain grade levels (ODE Assistant Superintendent, Equity Unit, personal communication, January 17,2014$)$. The majority of those programs targeted native-Spanish speakers.

Hence, a dual language endorsement is relevant and could improve the competencies required for bilingual teachers and reading specialists who teach nativeEnglish and native-Spanish speakers in the state. The following recommendations, even though they are numbered, are not listed in order of importance or priority:

1. Support and assess the implementation of the recently adopted dual language competencies, in a thoughtful and effective manner. 
2. Survey in-service bilingual teachers in one-way and two-way bilingual programs to conduct a needs assessments regarding biliteracy instructional and assessment practices.

3. Identify biliteracy competencies for the dual language specialty.

4. Require current ESOL/Bilingual teachers to take courses or professional development specific to biliteracy in order to renew their license.

5. Include linguistics and comparative linguistic courses as part of the reading endorsement programs offered at the state.

6. Encourage collaboration among teacher education programs as they design and implement dual language endorsement programs.

7. Encourage teacher preparation programs to have required courses for the dual language endorsement taught in Spanish in order to support Spanish academic language development and improve Spanish language proficiency in Spanish for teachers who will teach in Spanish-English bilingual programs.

8. Besides language competency, biliteracy skills development for teachers is also an important step in preparing qualified teachers (Blum Martinez \& Baker, 2010; Flores et al., 2011).

The creation of a dual language endorsement in Oregon would address the current gap in professional standards in the state by addressing not only academic language proficiency in Spanish, but also including specific knowledge in biliteracy pedagogy and transference from Spanish to English literacy that are lacking in the ESOL/Bilingual endorsement.

School district administrators. According to Fowler (2004), education policies are implemented by district administrators, principals and classroom teachers. Thus, if the gap in bilingual teacher preparation is felt at the practitioners -or grassroots - level, it becomes the school district administrators' responsibility to voice the need for more specific courses as part of the pedagogical preparation for bilingual teachers. Principals and district office administrators in their capacity as public leaders are "in a position to 
exercise influence on the policy process at the state and federal levels" (Fowler, 2004, p. 22).

Moreover, as an immediate response to the gap in bilingual teacher preparation in biliteracy and policy requirements for bilingual endorsed teachers, school districts could create partnerships with teacher preparation programs to provide professional development in biliteracy. I present recommendations for school district administrators that can take effect immediately. These do not necessarily require changes in policy in order to be implemented but rather partnerships between teacher preparation programs and schools. Some of these recommendations align with the Oregon English Learners Strategic Plan and provide concrete ideas to materialize its vision and goals. The following recommendations, even though they are numbered, are not listed in order of importance or priority:

1. Recognize that there are linguistic differences in literacy development between English and Spanish, explore and learn about these differences, and support bilingual reading teachers and reading specialists to learn how to best address biliteracy.

2. Provide professional development that specifically addresses biliteracy, inviting experts that recognize and incorporate research that addresses not just English literacy research and instructional practices.

3. Identify, select and prepare a bilingual reading specialist to keep up with current research on biliteracy and build in time for this person to read relevant literature and disseminate the information and resources gathered among bilingual teachers in the district.

4. Build time in the schedule of bilingual reading specialists to read professional literature in biliteracy and collaborate to evaluate reading resources available at school. They, in turn, can collaborate with bilingual teachers and explore curriculum materials and how to best use them in Spanish literacy classes.

5. Create time and space for Spanish-English bilingual teachers to collaborate with bilingual reading specialists and university faculty to learn about biliteracy. 
6. Collaborate with teacher preparation programs to conduct research in biliteracy in the dual language programs.

7. Increase the number of books in Spanish at the library and the Spanish books available for reading bilingual reading specialists to use during reading intervention groups.

8. Contact the Mexican Consulate to obtain Spanish books available to students in Mexico and arrange for professional development meeting in which Mexican educators explain how those books are used to maximize student learning.

9. Send bilingual teachers and reading specialists to local conferences that focus on bilingual education and biliteracy such as the English Learner Conference or the Oregon Association for Multicultural Education in Oregon.

10. Send bilingual reading specialists or bilingual instructional coaches to national conferences such as the California Association for Bilingual Education Conference in California, or the La Cosecha Dual Language Conference in New Mexico. Organize a session where the teachers that attended these conferences can disseminate the information or strategies they learned with bilingual staff at the district.

11. Invite professional associations to schools to promote their work and support professional memberships for bilingual teachers.

12. Arrange visits to schools with dual language programs in the state that have been identified by ODE as exemplary and/or invite teachers from those programs to come to the district and share their experience and expertise regarding biliteracy.

13. Identify exemplary bilingual teachers and bilingual reading specialists and assign them as cooperating teachers to mentor pre-service bilingual teachers.

14. Create workshops or meetings for Spanish-speaking parents, in Spanish, to learn how the school system works in the United States and to encourage parent participation.

15. Create workshops or meetings for teachers to explore cultural differences and expectations from Spanish-speaking parents. Address teachers' cultural assumptions and promote culturally competent ways to approach and engage Spanish-speaking parents.

16. Support the adoption of a dual language endorsement in the state. 
A school district committed to maintaining and improving effective bilingual programs should assign district funds to support professional development focused on biliteracy. They also have the ability to request this specific type of professional development from teacher preparation programs. School administrators with a vision and commitment to diversity and equity, as organizational leaders, can move bilteracy practices forward before policy changes take place.

Teacher preparation programs. The lack of specific requirements from TSPC regarding biliteracy pedagogy courses in bilingual teacher preparation programs leaves a gap in the knowledge and skills of bilingual teachers who do not receive these courses as part of their professional preparation program (Blum Martinez \& Baker, 2010). Universities that are committed to bilingual education and want to prepare bilingual teachers effectively must analyze their current programs to determine whether they are adequately meeting the needs of bilingual teachers.

The approval of a dual language specialty by TSPC constitutes a step in the right direction to improve the preparation of bilingual teachers. Nonetheless, besides pursuing a dual language specialty, teacher preparation programs could form partnerships with school districts and provide professional development in biliteracy. The following recommendations, even though are numbered, are not listed in order of importance or priority:

1. Form partnerships with school districts and provide professional development that addresses biliteracy pedagogy and academic Spanish for teachers who have not yet received this preparation.

2. Incorporate biliteracy pedagogy courses in their curriculum to assure that bilingual teacher candidates receive these courses during their program prior to their initial license. 
3. Include comparative linguistic courses for Spanish and English to address differences and similarities in these languages to inform instructional practices.

4. Offer courses taught in Spanish as part of the current ESOL/Bilingual endorsement or the proposed dual language endorsement.

5. Prepare bilingual teachers and reading specialists with skills necessary to work collaboratively. Develop these skills during course work assignments and during their clinical practice experiences.

6. Partner with other universities and offer a bilingual reading endorsement with courses that specifically focus on biliteracy and include current research on biliteracy.

7. Work alongside other universities and districts to conduct research in biliteracy in one-way and two-way bilingual programs aimed at improving student learning.

8. Collaborate among different universities to design licensure programs for the proposed dual language endorsement.

9. Offer a multi-university dual language endorsement program to maximize the expertise of faculty in terms of biliteracy as each program continues to build capacity internally.

10. Collaborate with community colleges and early childhood development programs to address the specific needs of biliteracy preparation for early childhood educators. This would support the biliteracy development of language minority students entering public schools and dual language programs.

11. Demonstrate a positive disposition toward minority students and acknowledge language as an asset through their curriculum. Cultivate these dispositions among their initial teacher candidates, bilingual or not.

12. Include an action research or self-study for teacher candidates to analyze their beliefs and assumptions working with linguistically and culturally diverse students during the initial teacher preparation program.

13. Identify exemplary bilingual teachers and reading specialists and request clinical field experiences with those teachers.

14. Include a project during the clinical practice where bilingual teachers and reading specialists collaborate with families to explore and incorporate funds of knowledge (McIntyre et al., 2001) and parents' literacy practices to support students' biliteracy development. 
15. Collaborate with ODE in the creation and dissemination of research and resources pertinent to biliteracy pedagogy.

The recommendations listed above would advance the preparation of bilingual teachers and reading specialists, demonstrating proactive steps to equality and social justice in the education of ELs in P-12 settings. Universities need to recognize the political nature of education and take a stand. Changes in the preparation of bilingual teachers and reading specialists start from ideological conceptualizations of bilingual education (Bartolomé, 2000; Flores et al., 2011; Nieto, 2000a). If we want bilingual education to support the learning of bilingual students and we see their linguistic diversity as an asset, then teacher preparation programs must equip bilingual teachers and reading specialists to teach in bilingual developmental models and not perpetuate an assimilationist curriculum.

\section{Limitations of the Study}

I have identified three limitations to this study. The first one is the narrow focus on Spanish-English biliteracy. While $76 \%$ of ELs in Oregon speak Spanish, my study did not address the understanding of the phenomenon of biliteracy for bilingual reading specialists who teach other languages,-such as Russian, Mandarin and Japanese- to Oregon students in dual language programs around the state.

The second limitation for the study is that it captured the lived experiences of female bilingual reading specialists in one school district in Oregon. In this sense, the study only represented participants who experienced the same educational context and bilingual education programs besides being from the same gender. The lack of 
representation from other voices could be addressed through further research, expanding the pool of participants to other districts and including men in future studies.

A third limitation is that even though I was careful to write an Epoche and tried to abstain from judgment and personal bias, I conducted my study under a critical pedagogy framework with the understanding that native-Spanish speaking students and nativeSpanish speaking bilingual reading specialists were part of a linguistic and culturally minority group in the United States. I viewed the participants' responses under this framework, connecting their beliefs and experiences to the historic marginalization that minority groups have experienced in the U. S. Furthermore, as a native-Spanish speaking bilingual educator, I identified myself with two of the participants who shared similar ethnic and cultural backgrounds. Additionally, as a former teacher at this school district, I was familiar with the context and had experience teaching biliteracy to the student population with whom participants worked. Therefore, my preconceptions and prior beliefs or experiences were limitations to this study as personal bias may have affected the interpretation and analysis of the data.

\section{Future Research}

This study opens the doors to other potential studies that could further explore the experiences of bilingual reading specialists in other school settings. The following prospective studies could be derived from the findings in this study:

1. A study of bilingual reading specialists and the leadership roles they take as teacher experts when collaborating with colleagues. This could focus on collaboration with in-service teachers or with new teachers who seek their mentorship.

2. A study of bilingual reading specialists and the leadership roles they take as teacher experts when collaborating with pre-service teachers. This could 
explore the impact of mentorship in the preparation of bilingual teachers and reading specialists.

3. A study of bilingual reading specialists and the leadership roles they take as teacher experts when collaborating with parents. An analysis of parental views and literacy practices at home as result of this collaboration would be important to explore. Also, it would be important to analyze teacher perceptions and beliefs of home literacy practices and how these views impact collaboration.

4. A study that examines how Teacher Preparation Programs in Oregon prepare bilingual reading specialists. This study could make a comparison of the current practices and those that would be implemented with the adoption of a dual language specialty.

5. A study that explores the same research question-How does a bilingual reading specialist understand the phemomenon of teaching biliteracy to bilingual students? - but expands the participant pool to Spanish-English bilingual reading specialists from other school districts who teach in the dual language programs at the elementary and/or middle school levels. A subsequent study could also explore this question with other languages besides Spanish.

6. A study of how bilingual children understand the phenomenon of biliteracy. It is important to explore the lived experiences of students -in and outside school- to better situate instructional methods in students' cultural contexts (Bartolomé, 1994).

7. A study of the environments bilingual reading specialists create to engage and motivate students to read. This study could include an analysis of how bilingual reading specialists adopt, adapt and navigate the English literacy strategies they learn into their Spanish literacy instruction in light of their commitments to biliteracy (Spencer, Falchi, \& Ghiso, 2011).

\section{Personal Reflections}

I started this research motivated by a desire to learn from practitioners in the field who were teaching biliteracy in bilingual and dual language programs. I was looking for their insights to inform the preparation of future bilingual teachers and reading specialists. As I shared in the Epoche (see Appendix B), I was a bilingual teacher who, after receiving an initial teaching license and an ESOL/Bilingual endorsement, had 
questions about teaching biliteracy. These questions had to do with effective literacy teaching methodology at first. However, as I learned about critical pedagogy and explored teaching and learning through political lenses during my doctoral studies, I understood that there was a lot more to teaching than methodology (Bartolomé, 1994). Teaching and policies that drive education originate in ideology (Bartolomé, 1994; Macedo \& Bartolomé, 2014). There is a prevalent Anglocentric ideology that drives literacy instruction in the United States (Escamilla, 2014; Goldenberg et al., in press; Jimenez et al., 1999; Johnson, 2013) and supports subtractive bilingualism. This ideology has influenced the value given to literacy practice in schools. For instance, when I started teaching at a bilingual school, the syllabic method that Mexican teachers were using to teach literacy in Spanish was not regarded as valid as the English literacy methods, such as whole language. Regardless of the number of years that Mexican teachers had taught in Mexico, their instruction was not viewed as legitimate since it did not follow English literacy research.

Likewise, this ideology of English hegemony (Macedo et al., 2003) has permeated scholarly research in literacy and thus influenced literacy instruction (Escamilla, 2006, 2014). Recent studies on biliteracy stress the need for more research on biliteracy with emergent bilinguals in the United States (Escamilla, 2006; Escamilla, Hopewell et al., 2014; Goldenberg et al., in press; Lindholm-Leary, 2012). However, my concern is that as much as we need these studies, their results may be overlooked by a still prevalent Anglocentric view of literacy research and practices in this country. I cannot help but wonder if new studies that focus on native-Spanish speaker students and biliteracy will be 
accepted by the literacy community. Would those studies challenge major assumptions (Macedo \& Bartolomé, 2014) about literacy acquisition and provide insights into the biliteracy development of emergent bilinguals in the United States?

As a bilingual teacher educator, my professional responsibility is to use this research to improve my teaching and to restructure the courses and the programs in which I take part. I want to provide pre-service teachers with a comprehensive education that also helps them to identify, analyze and evaluate the ideology behind teaching practices. Participants in this study showed me that their desire to effectively teach students and their commitment to additive views of bilingualism and biliteracy were a driving force for what they do. Participants collaborated with colleagues and parents and created caring environments that addressed individual student needs, valued Spanish language and culture, and cultivated students into lifelong readers who enjoy reading.

The insights gained through the interviews and my new understandings of how ideology influences educational policies and practices point to the need of a teacher preparation program that is rooted in critical pedagogy. The model that Flores et al. (2011) proposed to prepare bilingual teachers presents an alternative to subtractive approaches that may emphasize cultural competency but leave behind linguistic considerations for teaching ELs in two languages. Their recommendations are worth exploring not only by faculty who teach in ESOL/Bilingual programs but also by faculty responsible for Reading endorsement programs. 


\section{Final Thoughts}

When it comes to preparing bilingual teachers and reading specialists, educational ideology is reflected at the level of bilingual programs, the research conducted in biliteracy, the curricula set forth by teacher preparation programs, the instructional practices of bilingual faculty, and policies regarding teacher preparation. It is important that all these components align to prepare bilingual teachers and reading specialists who can enhance and transform bilingual education. These teachers have to be adequately and effectively prepared to teach in two languages. They also need to commit to social justice by means of advocating for maintenance and additive bilingual programs that develop biliteracy among bilingual students and prepare them to succeed academically.

The preparation of bilingual teachers in Oregon has been influenced by national education trends that aim to assimilate bilingual students into mainstream instruction. The emphasis has been on preparing teachers to teach in English rather than in the students' home language. Policies at the federal level, such as NCLB requirements of measuring bilingual student progress through English exams, influence more than just school district practices. These trends toward English assimilation are also captured by organizations that regulate the preparation and licensure of teachers. However, these national trends can be challenged at the state level by effective initiatives and policies that support additive models of bilingual education.

Oregon has seen drastic improvements in the policies that guide the instruction of ELs in the state this past year. The adoption of an English Learner Statewide Strategic Plan by ODE set the agenda to move away from deficit views and subtractive models of 
bilingual education for ELs in the state. TSPC requirements for initial licensure are changing due in part to ODE's equity initiatives as well as the work of stakeholders who put forth the Dual Language competencies initiative. Goal \#7 of the English Learners Statewide Strategic Plan moved forward TSPC's adoption of Knowledge Skills and Abilities for English Language Learner Proficiencies for all General Educator Preparation Programs and Faculty that will prepare all initial teachers with the skills they need to better serve ELs (Rosselli \& Menk, 2014). While these proficiencies target English instruction for ELs, the newly adopted Dual Language competencies by TSPC open the door for improving the preparation of bilingual teachers and reading specialists to address students' two languages and contribute to their biliteracy development.

Nieto (2000b) stated that "teacher education programs have a critical role to play in pushing the agenda for social justice and equity in our nation's schools" (p. 186). At this time in Oregon it is crucial that teacher preparation programs collaborate to create effective programs that will prepare bilingual teachers and reading specialists to develop biliteracy skills and provide quality learning experiences to bilingual students. The creation of dual language specialty programs has to be carefully planned and implemented. Special attention needs to be given to biliteracy. It is not only the right thing to do, but it needs to be done for the right reasons: the advancement of teacher preparation programs that equip bilingual teachers and reading specialists to teach biliteracy and promote social change that will result in equity for ELs .

If teacher preparation programs in Oregon are going to improve the ability of bilingual teachers and reading specialists to effectively develop biliteracy skills and 
support bilingual students to meet state standards, they must act now. It is critical that bilingual teachers and reading specialists working with ELs , particularly in early childhood programs and primary grades, value language and be capable of developing strong biliteracy skills in students. Bilingual teachers and reading specialists support ELs to be proficient in two languages and become bicultural. They play a critical role in supporting biliteracy development and students' academic success. Thus, it is the responsibility of teacher preparation programs in Oregon to ensure that we equip bilingual teachers and reading specialists with courses and professional development that address not only cultural competency but also address the linguistic diversity, complexity, and particular needs of children who learn to read and write in two languages. Furthermore, it is the responsibility of administrators and policymakers to create the necessary conditions to support additive models of bilingual education that allow students to become fully bilingual, biliterate and bicultural to be world citizens in the $21^{\text {st }}$ century. 


\section{REFERENCES}

Abedi, J. (2004). Assessment accommodations of English language: Implications for policy-based empirical research. Review of Educational Research, 74(1), 1-28.

Alfaro, C., \& Quezada, R. L. (2010). International teacher professional development: Teacher reflections of authentic teaching and learning experiences. Teaching Education, 21(1), 47-59.

Alvarez, J. (2010). Rapunzel's Ladder (foreword). In K. Skubikowski, C. Wright, \& R. Graf (Eds.), Social justice education: Inviting faculty to transform their institutions (pp. xiii-xxiv). Sterling, VA: Stylus Publishing.

Andrade, A.M., Basurto, A., Ruiz, O. A., Clay, M., \& Escamilla, K. (1996). Instrumento de observación de los logros de la lecto-escritura inicia: A bilingual text [Spanish reconstruction of an observation survey: A bilingual text]. Porstmouth, NH: Heineman.

Arteagoitia, E., Howard, E., Loguit M., Melabonaga, V., \& Keyton, M. (2005). The Spanish developmental contrastive spelling test: An instrument for investigating intra-linguistic and crosslinguistic influences on Spanish-spelling development. Bilingual Research Journal, 29(3), 541-560.

August, D., \& Shanahan, T. (2008). Developing reading and writing in second-language learners: Lessons from the report of the national literacy panel on languageminority children and youth. New York, NY: Routledge.

August, D., Snow, C., Carlo, M., Proctor, P. C., de San Francisco, A. R., Duursma, E., \& Szuba, A. (2006, October). Literacy development in elementary school secondlanguage learners. Topics in Language Disorders, 26(4), 351-364.

Ballantyne, K. G., Sanderman, A. R., \& Levy, J. (2008). Educating English language learners: Building teacher capacity. Washington, DC: National Clearinghouse for English Language Acquisition. Retrieved March 2013, from http://www.ncela.us/ files/uploads/3/EducatingELLsBuildingTeacherCapacityVol1.pdf

Bartolomé, L. I. (1994). Beyond the methods fetish: Toward a humanizing pedagogy. Harvard Educational Review, 64(2), 173-193.

Bartolomé, L. I. (2000). Democratizing bilingualism: The role of critical teacher education. In Z. F. Beykont (Ed.), Lifting every voice: Pedagogy and politics of 
bilingualism (pp. 167-186). Cambridge, MA: Harvard Education Publishing Group.

Beeman, K., \& Urow, C. (2013). Teaching for biliteracy: Strengthening bridges between languages. Philadelphia, PA: Caslon Publishing.

Bialystok, E. (2007). Acquisition of literacy in bilingual children: A framework for research. Language Learning, 57(1), 45-77.

Blum Martinez, R., \& Baker, S. (2010). Preparing teachers of bilingual students. Yearbook of the National Society for the Study of Education, 109(2), 319-350.

Bruner, J. (1996). The culture of education. Cambridge, MA: Harvard University Press.

Caaps, R., Fix, M., Murray, J., Ost, J., Passel, J., \& Herwantoro, S. (2005). The new demography of America's schools: Immigration and the No Child Left Behind Act. Washington, DC: The Urban Institute.

Cárdenas-Hagan, E., Carlson, C., \& Pollard-Durodola, S. (2007). The cross-linguistic transfer of early literacy skills: The role of initial L1 and L2 skills and language of instruction. Language, Speech, and Hearing Services in Schools, 38, 249-259.

Clark, E., Jackson, L., \& Prieto, L. (2011). Identity: A central facet of culturally efficacious bilingual education teachers. In B. B. Flores, R. H. Sheets, \& E. R. Clark (Eds.), Teacher preparation for bilingual student populations: Educar para transformar (pp. 27-39). New York, NY: Routledge.

Clay, M. (2005). An observation survey of early literacy achievement $\left(2^{\text {nd }}\right.$ ed.) Portsmouth, NH: Heineman.

Cloud, N., Genesee, F., \& Hamayan, E. (2000). Dual language instruction: A handbook for enriched education. Boston, MA: Heinle.

Collier, C. (2008). Dr. Collier's glossary for crosscultural, ESL, ELL, bilingual, and special education. Retrieved from http://www.wce.wwu.edu/Resources/ CIRCLE/Glossary/Glossary\%2008.pdf

Council of Chief State School Officers. (2011). Interstate Teacher Assessment and Support Consortium (InTASC) model core teaching standards: A resource for state dialogue. Washington, DC: Author. Retrieved on August 15, 2012, from http://skc.edu/sites/default/files/InTASC_Model_Core_Teaching_Standards_2011 .pdf

Crawford, J. (1996). Summing up the Lau decision: Justice is never simple. Retrieved December 30, 2010, from http://www.languagepolicy.net/articles/summing.htm 
Crawford, J. (2001, November). La educación bilingüe en Estados Unidos: Política versus pedagogía [Bilingual education in the United States: Policy versus pedagogy]. Paper presented at I Jornadas Internacionales de Educación Plurilingüe, Ayuntamiento de Vitoria-Gasteiz, País Vasco, España [International Conference of Multilingual Education, Victoria-Gasteiz, Basque Country, Spain].

Crawford, J. (2004a). Educating English learners: Language diversity in the classroom $\left(5^{\text {th }}\right.$ ed.). Los Angeles, CA: Bilingual Educational Services.

Crawford, J. (2004b, September 14). No child left behind: Misguided approach to school accountability for English language learners. Presentation at a forum sponsored by the Center on Education Policy, San Diego, CA. Retrieved December 28, 2010 from http://users.rcn.com/crawj/langpol/Crawford_NCLB_Misguided_Approach_for_ ELLs.pdf

Creswell, J. W. (2007). Qualitative inquiry and research design: Choosing among five approaches (2nd ed.). Thousand Oaks, CA: Sage Publications

Cummins, J. (1991). Interdependence of first- and second-language proficiency in bilingual children. In E. Bialystok (Ed.), Language processing in bilingual children (pp. 70-89). Cambridge, UK: Cambridge University Press.

Darling-Hammond, L. (2006). Constructing 21st-century teacher education. Journal of Teacher Education, 57(10), 1-15. Retrieved from http://ewa.convio.net/docs/linda_darlinghammond_article1.pdf

Darling-Hammond, L., \& Bransford, J. (2005). Preparing teachers for a changing world: What teachers should learn and be able to do. San Francisco, CA: Jossey-Bass.

Diaz-Rico, L., \& Weed, K. (2010). The crosscultural, language, and academic development handbook: A complete $K-12$ reference guide ( $4^{\text {th }}$ ed.). Boston, MA: Allyn \& Bacon.

Díaz-Soto, L. (2011). Implementing a critical bilingual/bicultural pedagogy (afterword). In B. B. Flores, R. H. Sheets, \& E. R. Clark (Eds.), Teacher preparation for bilingual student populations: Educar para transformar (pp. 239-242). New York, NY: Routledge.

Echevarria, J., Vogt, M., Short, D. (2010). Making content comprehensible for secondary English learners: The SIOP model. Boston, MA: Allyn \& Bacon.

Escamilla, K. (2006). Semilingualism applied to the literacy behaviors of Spanishspeaking emerging bilinguals: Bi-illiteracy of emerging biliteracy? Teachers College Record, 108(11), 2329-2353. 
Escamilla, K. (2014, March). Bilingualism and biliteracy: Preparing all students for the 21st century. Presentation at the State English Learners Alliance conference, Eugene, OR.

Escamilla, K., Hopewell, S., Butvilofsky, S., Sparrow, W., Soltero-González, L., RuizFigueroa, O., Escamilla, M. (2014). Biliteracy from the start: Literacy squared in action. Philadelphia, PA: Caslon.

Escamilla, K., Ruiz-Figueroa, O. A., Hopewell, S., Butvilofsky, S., \& Sparrow, W. (2010). Transitions to biliteracy: Literacy Square 2004-2009 final technical report. Boulder, CO: University of Colorado. Retrieved from http://literacysquared.org/www/www/source/Lit2\%20Technical\%20Manual\%20P hase\%20I.pdf

Fitzgerald, J. (2000). How will bilingual/ESL programs in literacy change in the next millennium? Reading Research Quarterly, 35(4), 520-521.

Flores, B. B., Sheets, R. H., \& Clark, E. R. (2011). Teacher preparation for bilingual student populations: Educar para transformar. New York, NY: Routledge.

Fowler, F. C. (2004). Policiy studies for educational leaders: An introduction ( $2^{\text {nd }}$ ed.). Upper Saddle River, NJ: Pearson.

Freeman, Y., Freeman, D., \& Mercuri, S. (2005). Dual language essentials for teachers and administrators. Portsmouth, NH: Heinemann.

Freire, P. (2000). Pedagogía del oprimido [Pedagogy of the oppressed]. México, DF: Siglo Veintiuno Editores (traducido por Jorge Mellado) [Century Twenty-One Editors (translated by Jorge Mellado)].

Freire, P., \& Macedo, D. (2002). Rethinking literacy: A dialogue. In A. Dader, M. Baltodano, \& R. Torres (Eds.), The critical pedagogy reader (pp. 354-364). New York, NY: Routledge.

García, O., Kleifgen, J. A., \& Falchi, L. (2008). From English language learners to emergent bilinguals (Equity Matters: Research Review No. 1). New York, NY: Teachers College Columbia University

Genesee, F., Geva, E., Dressler, C., \& Kamil, M. (2008). Cross-linguistic relationships in second language learners. In D. August \& T. Shanahan (Eds.), Developing reading and writing in second-language learners: Lessons from the report of the national literacy panel on language-minority children and youth (pp. 61-94). New York, NY: Routledge. 
Geneva G., \& Tyrone C. H. (2000) Multicultural teacher education for the 21 st century, The Teacher Educator, 36(1), 1-16.

Gay, G. (2000). Culturally responsive teaching: Theory, research, and practice. New York, NY: Teachers College Press.

Gay, G. (2002). Preparing for culturally responsive teaching. Journal of Teacher Education, 53(2), 106-116.

Gay, G., \& Howard, T. C. (2000). Multicultural teacher education for the $21^{\text {st }}$ century. The Teacher Educator, 36(1), 1-16. doi:10.1080/08878730009555246

Gersten, R., \& Brengelman, S. (1994). Effective instruction for culturally and linguistically diverse students: A reconceptualization. Focus on Exceptional Children, 27(1), 1-16.

Giroux, H. (2002). Critical theory and educational practice. In A. Dader, M. Baltodano, \& R. Torres (Eds.), The critical pedagogy reader (pp. 27-56). New York, NY: Routledge.

Goldenberg, C. (2008, Summer). Teaching English language learners: What the research does-and does not-say. American Educator. Retrieved May 29, 2012, from http://www.edweek.org/media/ell_final.pdf

Goldenberg, C., Tolar, T. D., Reese, L., Frances, D. J., Ray, A., \& Mejía-Arauz, R. (in press). How important is teaching phonemic awareness to children learning to read in Spanish? American Educational Research Journal-Teaching, Learning and Human Development. Retrieved from: https://openarchive.stanford.edu/sites/default/files/PASpanReadingFINALACCE PTED_1.pdf

Gonzaléz, N., Moll, L., \& Amanti, C. (2005). Funds of knowledge: Theorizing practices in households, communities, and classrooms. Mahwah, NJ: Lawrence Erlbaum Associates.

Guerrero, M. D. (1997). Spanish academic language proficiency: Spanish academic language proficiency: The case of bilingual education teachers in the U.S. Bilingual Research Journal, 21(1), 65-84.

Guerrero, M. D., \& Guerrero, M. C. (2009). El (sub)desarrollo del español académico entre los maestros bilingües: ¿Una cuestión de poder? [The (under)development of academic Spanish among bilingual teachers: An issue of power?]. Journal of Latinos and Education, 8(1), 55-66. 
Guerrero, M. D., \& Valadez, C. M. (2011). Fostering candidate Spanish language development. In B. B. Flores, R. H. Sheets, \& E. R. Clark (Eds.), Teacher preparation for bilingual student populations: Educar para transformar (pp. 59-72). New York, NY: Routledge.

Hedgcock, J. (2005). Taking stock of research and pedagogy in L2 writing. In E. Hinkel (Ed.), Handbook of research in second language teaching and learning (pp. 597613). Mahwah, NJ: Erlbaum.

Hudson, R. F., \& Smith, S. W. (2001). Effective reading instruction for struggling Spanish-speaking readers: A combination of two literatures. Intervention in School and Clinic, 37(1), 36-39.

International Reading Association. (n.d.). An executive summary of the national commission on excellence in elementary teacher preparation for reading instruction. Newark, DE: Author.

International Reading Association. (2010). Standards for reading professionals-Revised 2010. Newark, DE: Author. Retrieved from http://www.reading.org/general/CurrentResearch/Standards/ProfessionalStandards2010.a $\operatorname{spx}$

Jimenez, R. T., Moll, L. C., Rodríguez-Brown, F. V., Barrera, R. B. (1999). Latina and Latino researchers interact on issues related to literacy learning. Reading Research Quarterly, 34(2), 271-230.

Johnson, S. I. (2013). Dual language teachers' changing views of Spanish literacy teaching and learning as influenced by critical dialogue (Unpublished doctoral dissertation). The University of New Mexico, Alburqueque, NM.

Kern, D. (2011). 62 years of the pendulum's swing: The role of the reading specialists. The NERA Journal, 42(2), 67-72.

LaForce, B., Cevallos, T., \& Torres, M. (2009, February). An examination of a reading endorsement program with courses in English and Spanish. Paper presented at the annual Oregon Association of Teachers Educators Conference, Portland, OR.

Lincoln, Y., \& Guba, E. (2000). Paradigmatic controversies, contradictions, and emerging confluences. In Y. Lincoln \& E. Guba (Eds.), Handbook of qualitative research (pp. 163-188). Thousand Oaks, CA: Sage Publications.

Lindholm-Leary, K. (2004). The rich promise of two-way immersion. Educational Leadership, 62(4), 56-59. 
Lindholm-Leary, K. (2012). Success and challenges in dual language education. Theory into Practice 51(4), 256-262.

Macedo, D. (2000). The colonialism of the English only movement. Educational Researcher, 29(15), 15-24.

Macedo, D., \& Bartolomé, L. (2014). Multiculturalism permitted in English only. International Multilingual Research Journal, 8(1), 24-37.

Macedo, D., Dendrinos, B., \& Gounari, P. (2003). The hegemony of English. Boulder, CO: Paradigm.

Maloch, B., Flint, A., Eldridge, D., Harmon, J., Loven, R., Fine, J., Bryant-Shaklin, M., \& Martinez, M. (2013). Understandings, beliefs, and reported decision making of first-year teachers from different reading teacher preparation programs.

Elementary School Journal, 103(5), 431-457.

Manner, J. C., Rodriguez, D., \& Davis, K. (2010). NCATE standard four: Rural teachers leading the way. The Journal of Multiculturalism in Education, 6(2). Retrieved January 4, 2012, from http://www.multiculturaljournal.com/volumes/ 6/pdf/manner.pdf

Maxwell, J. (2005). Qualitative research design: An interactive approach ( ${ }^{\text {nd }}$ ed.). Thousand Oaks, CA: Sage.

Maxwell, J. (2009). Designing a qualitative study. In L. Bickman \& D. J. Rog (Eds.), The handbook of applied social research methods (2nd ed.; pp. 214-253). Thousand Oaks, CA: Sage.

McIntyre, E., Rosebery, A., \& González, N. (2001). Classroom diversity: Connecting curriculumto students' lives. Portsmouth, NH: Heinemann

McLaren, P. (2002). Critical pedagogy: A look at the major concepts. In A. Dader, M. Baltodano, \& R. Torres (Eds.), The critical pedagogy reader (pp. 69-96). New York, NY: Routledge.

Mercuri, S., \& Rodriguez, A. (2013, March). Preparing every teacher: The next generation of teacher education. Presentation at the TESOL International Convention conference, Dallas, TX.

Mora, J. K. (2009). From the ballot box to the classroom. Educational Leadership, 66(7), 14-19.

Moustakas, C. (1994). Phenomenological research methods. Thousand Oaks, CA: Sage. 
National Clearinghouse for English Language Acquisition. (n.d.a). How many schoolaged limited English proficient (LEP) students are in the U.S.? Washington, DC: Author. Retrieved February 2010 from http://www.ncela.gwu.edu/faqs/view/4

National Clearinghouse for English Language Acquisition. (n.d.b). Types of language instructional educational programs (LIEPS). Washington, DC: Author. Retrieved June 2012 from http://www.ncela.gwu.edu/files/uploads/5/Language_ Instruction_Educational_Programs.pdf

National Clearinghouse for English Language Acquisition. (2009). Glossary of terms related to the education of linguistically and culturally diverse students. Washington, DC: Author. Retrieved March 2013 from http://www.ncela.gwu.edu/files/rcd/BE021775/Glossary_of_Terms.pdf

National Council for Accreditation of Teacher Education. (2010). Transforming teacher education through clinical practice: A national strategy to prepare effective teachers. Retrieved from http://www.ncate.org/LinkClick.aspx?fileticket= zzeiB1OoqPk\%3D\&tabid=715

Nieto, S. (2000a). Bringing bilingual education out of the basement, and other imperatives for teacher education. In Z. F. Beykont (Ed.), Lifting every voice: Pedagogy and politics of bilingualism (pp. 187-207). Cambridge, MA: Harvard Education Publishing Group.

Nieto, S. (2000b). Placing equity front and center: Some thoughts on transforming teacher education for a new century. Journal of Teacher Education, 51(3), 180-187.

No Child Left Behind Act of 2001 (2002.

Oldenski, T. (1997). Liberation theology and critical pedagogy in today's Catholic schools: Social justice in action. New York, NY: Garland Publishing.

Olivos, E., \& Sarmiento, L. (2006). Is there room for biliteracy? Issues in Teacher Education, 15(1), 69-84.

Oregon Administrative Rules (OAR) 584-065-0100, TSPC, Division 65, Endorsements for Initial and Continuing Teaching Licenses. Knowledge Skills and Abilities for English to Speakers of Other Languages. Retrieved May 17, 2013, from http://arcweb.sos.state.or.us/pages/rules/oars_500/oar_584/584_065.html 
Oregon Department of Education. (2005). Guidance for implementation of content support programs for ELLs (SET, SI, SDAI, SIOP, GLAD). Salem, OR: Author. Retrieved May 31, 2012, from http://www.ode.state.or.us/opportunities/grants/ nclb/title_iii/guidforimplemen-ell.pdf

Oregon Department of Education. (2011). Statewide report card: An annual report to the legislature on Oregon public schools 2010-2011. Salem, OR: Author. Retrieved on May 31, 2012, from http://www.ode.state.or.us/data/annreportcard/ rptcard2011.pdf

Oregon Department of Education. (2012). Statewide report card: An annual report to the legislature on Oregon public schools 2010-2011. Salem, OR: Author. Retrieved on March 17, 2013, from http://www.ode.state.or.us/data/annreportcard/ rptcard2012.pdf

Oregon Department of Education (2013a). Education investment board: Equity lens. Salem, OR: Author. Retrieved from http://www.ode.state.or.us/superintendent/ priorities/final-equity-lens-draft-adopted.pdf

Oregon Department of Education (2013b). Oregon English learners statewide strategic plan 2013-2016. Salem, OR: Author. Retrieved from http://www.ode.state.or.us/ opportunities/grants/nclb/title

Pérez, B., \& Huerta, M. E. (2011). Dynamic biliteracy: Teacher knowledge and practice. In B. B. Flores, R. H. Sheets, \& E. R. Clark (Eds.), Teacher preparation for bilingual student populations: Educara para transformar (pp. 115-130). New York, NY: Routledge.

Pinnell, G., \& Fountas, I. (2010). Benchmark assessment system: Grades K-2 (2 ${ }^{\text {nd }}$ ed.). Portsmouth, NH: Heinemann

Quezada, R., \& Alfaro, C. (2012). Moving pedagogic mountains. The Journal of Communication Language Magazine, 11(12), 19-22. Retrieved August 23, 2012, from languagemagazine.com/?page_id=4699

Ríos, F., \& Van Olphen, M. (2011). Preparando maestros: ESL candidate/teacher preparation. In B. B. Flores, R. H. Sheets, \& E. R. Clark (Eds.), Teacher preparation for bilingual student populations: Educar para transformar (pp. 164173). New York, NY: Routledge.

Risko, V. J., Roller, C. M., Cummins, C., Bean, R. M., Block, C., Anders, P. L., \& Flood, J. (2008). A critical analysis of research on reading teacher education. Reading Research Quarterly, 43(3), 252-288. 
Rodríguez, A. (2008). The role of Spanish in bilingual and ESL teacher education programs: Experiences and perceptions of prospective teachers. Southeastern Teacher Education Journal, 1(1), 85-93

Rosselli, H., \& Menk, K. (2014, March). Goal 7 of the EL strategic plan: Where we are and where we want to be. Presentation at the State English Learners Alliance conference, Eugene, OR.

Seidman, I. (2006). Interviewing as qualitative research: A guide for researchers in education and social sciences ( $3^{\text {rd }}$ ed.). New York, NY: Teachers College Press.

Shannon, S. (1995). The hegemony of English: A case study of one bilingual classroom as a site of resistance. Linguistic and Education, 7, 175-200.

Shenton, A. (2004). Strategies for ensuring trustworthiness in qualitative research projects. Education for Information, 22, 63-75.

Shin, S. J. (2013). Bilingualism in schools and society: Language, identity, and policy. New York, NY: Routledge.

Shor, I., \& Freire, P. (1987). A pedagogy for liberation: Dialogues on transforming education. New York, NY: Bergin \& Garvey Publishers.

Spencer, T. G., Falchi, L., Ghiso, M. P. (2011). Linguistically diverse children and educators (re)forming early literacy policy. Early Childhood Education Journal, 39, 115-123.

Teacher Standards and Practices Commission (n.d). English for speakers of other languages/bilingual endorsement (OAR 584-038-0085). Salem, OR: Oregon Secretary of State. Retrieved from http://arcweb.sos.state.or.us/pages/ rules/oars_500/oar_584/584_038.html

Teacher Standards and Practices Commission (2009). News release: New changes to ESOL endorsement. Salem, OR: Author. Retrieved from http://tspc.oregon.gov/ support/news_item.asp?id=364

Thomas, W., \& Collier, V. (2002). A national study of school effectiveness for language minority students' long-term academic achievement: Final report executive summary. Retrieved November 1, 2007, from http://crede.berkeley.edu/ research/llaa/1.1_es.html

Thomas, W., \& Collier, V. (2007). A five-year longitudinal program evaluation/audit of Woodburn (OR) school district English learner programs: Final report. Woodburn School District. Woodburn, OR: Woodburn School District. 
Valdés, G. (1996). Con respeto: Bridging the distances between culturally diverse families and schools: An ethnographic portrait. New York, NY: Teachers College Press.

Valenzuela, A. (1999). Subtractive schooling: U.S.-Mexican youth and the politics of caring. Albany, NY: State University of New York Press.

Van Manen, M. (1990). Researching lived experiences: Human science for an action sensitive pedagogy. Albany, NY: State University of New York Press.

Vaughn, S., Cirino, P., Linan-Thompson, S., Mathes, P., Carlson, C. D., Hagan, E. Pollard-Durodola, S. D., Fletcher, J., \& Francis, D. (2006). Effectiveness of a Spanish intervention and an English intervention for English-language learners at risk for reading problems. American Educational Research Journal, 43(3). 449479.

Vygotsky, L. (1978). Mind in society: The development of psychological processes (M. Cole, V. John-Steiner, S. Scribner, \& E. Souberman, Eds.). Cambridge, MA: Harvard University Press.

Wink, J. (2005). Critical pedagogy: Notes from the real world ( $3^{\text {rd }}$ ed.). Boston, MA: Pearson.

Wright, W. E. (2006). A catch-22 for language learners. Educational Leadership, 64(3), 22-27. 


\section{APPENDIX A}

INTERNATIONAL READING ASSOCIATIONSTANDARD 4: DIVERSITY 


\section{Standards 2010: Standard 4}

\section{Diversity}

Candidates create and engage their students in literacy practices that develop awareness, understanding, respect, and a valuing of differences in our society.

The Diversity Standard focuses on the need to prepare teachers to build and engage their students in a curriculum that places value on the diversity that exists in our society, as featured in elements such as race, ethnicity, class, gender, religion, and language. This standard is grounded in a set of principles and understandings that reflect a vision for a democratic and just society and inform the effective preparation of reading professionals.

The following are the major assumptions of the Standards 2010 Committee for developing this standard and its elements:

- Diversity will be as much a reality in the future as it is in our lives today and has been in the lives of our predecessors.

- There is a tradition of "deficit" thinking and discourse in the context of diversity and schooling. As a society, we are not far removed from a time when cultural deprivation was an accepted term.

- Diversity is a potential source of strength of a society to be encouraged not discouraged. Diversity is the basis for adaptability to change, and change is the only certainty in the future.

- Creating a curriculum that values diversity requires that teacher educators and teachers step outside their personal experiences within a particular linguistic, ethnic, or cultural group to experience the offerings of other groups.

- The elements of diversity in a society cannot be isolated within that society and certainly not within an individual. The elements of diversity interact in the form of multiple identities that may move from the background into the foreground as a function of the context and the moment.

- There is a danger in overgeneralizing (i.e., stereotyping) characteristics to all members of a group.

- Language-minority students need appropriate and different language and literacy instruction if they are to be successful academically while they learn English.

- It is the responsibility of teachers and schools not only to prepare learners in ways that value their diversity but also to prepare those learners to engage in active citizenship to redress areas of inequity and privilege.

Matrix of Standard Elements by Professional Roles

Research and Supporting Literature

\section{Retrieved from:}

http://www.reading.org/General/CurrentResearch/Standards/ProfessionalStandards2010/Professio nalStandards2010_Standard4.aspx 


\section{APPENDIX B}

EPOCHE 
Epoche

\section{Tell me about your teaching path. How did you get here, as a teacher?}

I started teaching adults. I was invited to teach French at the Alliance Française and received one year of professional development as part of a cadre of Ecuadorean teachers. The institute was trying to recruit and grow Ecuadorean teachers. I did that for about $3 \frac{1 / 2}{2}$ years. I felt in love with teaching languages and wanted to learn more about learning and bilingual education. So, I came to the USA to study bilingual education. I was fascinated by the opportunities that students had in school to become bilingual but had not thought that bilingual ed was seen as compensatory. Some of the inequalities about education that I learned in school applied directly to my home country context and I realized that I was raised as mainstream and as what Freire refers to as "oppressor."

I taught at an immersion school in Portland and had a hard time managing a classroom of eight students. All the classes I took talked about curriculum planning and lesson planning but I had not experience working with kids prior to my first job teaching. My knowledge was theoretical and I did not know how to keep the classroom engaged with little kids. They had some fun learning but they also took advantage of my inexperience. The one thing that I did was bond with them and develop their academic Spanish. I had a MS in education and all the theory in the world but that year was probably my practicum year without a cooperating teacher.

Then, my second year of teaching was a total different story. I worked with a class of 24 Hispanic students and classroom management and procedures worked marvelously. I learned that year how to structure readers' and writers' workshop and, without knowing it, I provided differentiated instruction in math, following some hands on curriculum and presenting developmentally appropriate lessons. I had a mentor teacher who was an expert at teaching math and had daily long chats about how to teach literacy with a reading resource teacher. I also started a teaching program at the university and my courses were relevant based on my daily experience teaching kids.

After a few years in the classroom I became a bilingual coordinator. That was the job I wanted when I was pursuing bilingual education. I recognized what my boss said about the importance of teaching first so I could understand what teachers go through and have first-hand experience working with teachers. I loved that job but time was consumed with papework. I learned a lot about teaching by reading and having to go to other classroom to support teachers.

That experienced led me to go back and work with adults, this time preparing pre-service teachers. I have read the literature about good practices and recognized that I did quite a 
few of those things in the classroom. I also like to get energized with my students enthusiasm and optimism about teaching and changing the world.

One of the things I miss about teaching elementary kids is working with Hispanic families and children. I also miss seeing their faces when they "got" something and seeing how their minds think about math problems or other issues. I think that I have now all, or most of all, the tools I would need to be an excellent elementary teacher.

\section{How did you first start teaching biliteracy? Can you describe your experience when you first started teaching biliteracy? What happened?}

I started teaching biliteracy with my second grade class. Prior to that, I was only responsible for teaching Spanish and the English teacher worked on the students L1 literacy at the immersion school. However, when I moved to the public school setting, I was responsible for developing students' L1 literacy in Spanish and an emergent literacy in English. At that time, students were transitioning to reading in English in fourth grade, so my main emphasis or formal instruction was in Spanish. I did not have a curriculum for teaching English literacy and the approach was more holistic but I can't say that I was intentional. I found kindergarten books for free in the staff lounge and brought those to the classroom. They were all in a box and I partnered up with a fifth grade class for buddy readings. The fifth graders would come to my class and use the emergent reading books to read to or to teach my kids how to read in English. There was some transition happening but it was not explicit.

I did see, though, how my niece was able to transfer her reading skills in Spanish to reading in English on a few occasions. The literature said that with oral proficiency in the other language, kids should be able to do this and she did to some extend. My most advanced readers in Spanish would have no problem reading in English; they also had good English and were considered TAG. I wondered how I could have helped all my readers to make these connections and developed literacy.

\section{What have you experienced in terms of your preparation to teaching biliteracy?}

It was not fully developed. I left the public school system with more questions that I had answers to. The majority of my preparation to teach literacy comes from English literacy research. The approach at the school district where I used to work was to show us what were best teaching practices in English and ask us to translate or apply them to Spanish. Even the book titles for students to read were available in Spanish as translation from English titles. 
I then conducted some independent research to learn about the topic and found some information about the importance to teach about transfer explicitly. For a long time I thought that we needed to adopt literacy practices from Spanish-speaking countries. However, the work that Escamilla has done points out the need to develop ad hoc research for bilingual populations given their unique setting in the US as a minority language that gets bilingual education partially during their elementary school years. I have followed her work and I am interested in the importance of teaching biliteracy simultaneously rather than introducing English after a few years of instruction only in L1.

In sum, I have not received formal preparation during my university courses and I missed the opportunity to take a reading endorsement with courses in English and Spanish. I look forward to learning from the teachers I will interview and to learn more about the topic so I could teach it to the pre-service teachers with whom I work now.

\section{Tell me more about the context of your experiences with biliteracy in the classroom and/or as a reading specialist?}

I have only worked as a classroom teacher or instructional coach. I was responsible for developing biliteracy in a one-way bilingual program that served Spanish-speaking children. I focused more on teaching students to read in Spanish because that was the emphasis for the grades I was working with and because a strong literacy in L1 will support the acquisition of literacy in L2.

I structured my literacy period following Fountas \& Pinnell model both for guided reading and writer's workshop.

I modeled reading in English during content classes like social studies or science but was not deliberate about helping students make connections between the two languages. I would point out some similarities, difference or cognates between the languages but I feel that I lacked phonemic knowledge to support students make the transition easily.

Also, I did not work much with English-speaking students who were learning to read in Spanish in TWI programs besides supporting their oral development in Spanish.

\section{Reconstruct a typical literacy period. What do you do in your classroom?}

I followed the gradual release of responsibility model. I would start with a read aloud, then have a mini-lesson. I then worked with centers while teaching two guided reading groups. My IA worked with the other two reading groups and then students would work independently. One of the centers included independent reading. This took about an hour. 
Then we worked on writing and had a writer's workshop. I presented a mini-lesson and then students wrote while I conferenced with individual students. We had time for writer's chair on some days and that's how we would end the literacy block that lasted either 90 minutes or two hours.

\section{Describe a memorable event in teaching biliteracy.}

I focused on teaching literacy in Spanish with my second and third graders. However, I partnered up with a fifth grade teacher to come to my class so his students could be reading partners with my class. I found little books from an English kinder or first grade literacy program at the teachers' lounge and brought them to my class for my students to use with their buddy readers from $5^{\text {th }}$ grade. I wanted to create and informal reading opportunity for my students to explore reading in English under the guidance of an older student.

The students were excited to read in English but it was somewhat challenging for fifth graders to read or teach reading to my students. So after the first visit I went to fifth grade and talked about what they experienced and how they could support my students. The books had few sentences and a lot of pictures. They may not have been interesting in terms of plot but I thought they would provide enough visual and simplicity for my students to transfer their reading skills into English.

The rationale at the time was that if students had enough fluency in English, they would use that knowledge and transfer their reading skills in L1 to English. Some students were better than others at doing that. They were the ones that spoke more English.

Nonetheless, these times were fun for students and brought up the importance in reading in two languages.

\section{Share an anecdote that exemplifies a key value or core belief about teaching biliteracy.}

One that comes to mind is talking about how different languages use different punctuation. For instance, I would teach a mini-lesson on using hyphens to signal conversation in Spanish and was excited how students would start using that in their own writing. At another point we will see how English uses quotation marks instead of hyphens.

One thing that bothered me, though was to see books translated into Spanish that used quotation marks or other English structures into Spanish. It bothered me because those books did not respect the Spanish structures and were a direct translation from English. It was important to me that we did not impose English structures into Spanish. 
I think that if you truly want to teach biliteracy you have to explore each language in authentic ways to capture its richness. It worries me that our bilingual students do not get exposed to circular ways of narrative because they don't have enough literature models to fully access that language. When we teach them to write in Spanish we follow English structures and I wonder to what extent we reduce their potential to develop a full bilingual command of Spanish when we impose English structures into Spanish.

\section{Tell me about what you do as a bilingual reading specialist?}

I have not been a bilingual reading specialist so I am unable to answer this question.

\section{Could you talk about your relationship with your students? With other teachers? With parents? With administrators?}

I had a good relationship with my students. They were for the most part Hispanic and young. I had a classroom that worked well and I created a room where routines were in place and students developed independence in their learning. I let students lead activities and allowed for choice during literacy centers. I also brought books on tape from Ecuador and wanted students to access more authentic literature. I was a somewhat strict teacher that tried to maximize learning time and I don't know to what extent I allowed time for students to play or chat during class. I did receive hugs and drawings from time to time and kept an interactive journal where I got to answer students questions about my personal live and learn more about theirs. This was one of the things that they enjoyed and waited eagerly every week when they would get their responses in the journal and would keep adding to our correspondence. I also kept a point system to reward table groups and each Friday, the winning table would get to bring their lunch to the classroom and we would have an opportunity to talk. I enjoyed learning about my students' lives at home and listening to their stories. This was an informal and casual way for us to get to know each other better.

With parents I had a good relationship but limited contact. I met parents during parent conferences or when they came to school. I communicated with them via students, sending notes on small papers home that students wrote. These notes included both praise for something students did well in class and a student reflection on behaviors that were not appropriate. Parents signed these papers and this allowed them to know on regular basis how students were doing. I also had sporadic letters sent to the whole class about activities we were doing at school.

I had a strong relationship with administrators. I would often approach them with suggestions and ideas of things I wanted to explore in the classroom. I was going to school to get my teaching license during the first years I was teaching at the public school 
so I was reading books and articles that were relevant to my teaching and to school initiatives. I was also invited to take part on a series of professional development regarding literacy and coaching and eventually started working at the district office as bilingual coordinator. I supported the work administrators did and advocated for the rights of bilingual students and additive models of bilingual education.

\section{If time and money were not an issue, what and how would you like to further learn about biliteracy?}

I would like to study for a semester or a year with Escamilla and the work they are doing with Literacy Square. I would like to see how teachers implement the lessons and make the connections between English and Spanish. I am interested in how they develop two languages at the same time and how they allocate instruction time and literacy goals for each language.

I would like to see how teachers work through their planning, conduct assessment to guide their instruction, and are being supported by their administrators. Dual language programs bring another piece to biliteracy which is native-English speakers learning Spanish. I do not have as much experience working with that population in developing Spanish, and I would like to learn about how to support teachers work with those students.

You are in front of a panel that includes principals, district administrators, people from TSPC, legislatures and professors. You are talking on behalf of bilingual reading specialists. What would you like them to know?

I would like them to know that Oregon is on the right track supporting dual language efforts as part of their equity work. That additive models of bilingual education benefit native-English speakers as much as they benefit language minority students. That the efforts have to be continuous and it is an investment on the long run.

I would also tell them that we need to better prepare teachers to work with English learners and that we have to value Spanish and prepare strong bilingual teachers. It would be important to create a coalition at the university level to better serve the needs of students and think of ways to collaborate and prepare teachers for biliteracy. I think that university programs would be stronger if we share the expertise at different universities and create a researched-based program to prepare bilingual candidates. Also, I think that the clinical experience for bilingual teachers is crucial and that school districts have to choose only the best and more knowledgeable models to serve as cooperating teachers. 
I also think that the efforts that bilingual teachers do at their own schools and district need to be shared across districts. A lot of time and effort is spent translating materials and creating lessons for dual language classes. When these lessons or materials have been effective, they should be available for other teachers to use. At this point there are only a few districts that have dual language programs. It is important for the teachers in those programs to be in contact with each other within the district and across the state. They may share similar issues and would benefit from addressing them together. 
APPENDIX C

INTERVIEW PROTOCOLS 
Interview Protocols

INTERVIEW PROTOCOL \#1
Participant Code:

\section{Understanding Biliteracy: Exploring the Lived Experiences of Bilingual Reading Specialists}

Time of Interview:

Date:

Place:

Interviewer: Tatiana Cevallos

This phenomenological study will explore, through interviews, the lived experiences of bilingual reading specialists in regards to teaching biliteracy.

Please answer the following questions, giving me as many details as possible. Think about your experience teaching biliteracy. Your answers will remain confidential and will be used for research purposes. Participation in this study is voluntary and you may stop at any time.

Q1-Tell me about your teaching path. How did you get here, as a teacher?

Q2-- How did you first start teaching biliteracy? Can you describe your experience when you first started teaching biliteracy? What happened?

Q3-What have you experienced in terms of your preparation to teaching biliteracy? 
INTERVIEW PROTOCOL \#2

Participant Code:

\section{Understanding Biliteracy: Exploring the Lived Experiences of Bilingual Reading Specialists}

Time of Interview:

Date:

Place:

Interviewer: Tatiana Cevallos

This phenomenological study will explore, through interviews, the lived experiences of bilingual reading specialists in regards to teaching biliteracy.

Please answer the following questions, giving me as many details as possible. Think about your experience teaching biliteracy. Your answers will remain confidential and will be used for research purposes. Participation in this study is voluntary and you may stop at any time.

I want to thank you for your time and honesty during this experience. I would like to read the notes from our previous interview and what you shared with me. Please let me know if I captured what you are trying to share about your experiences teaching biliteracy. Feel free to stop me at any time to change or add anything I may have missed during the transcript and interpretation process.

Follow up questions from data interpreted for first interview here.

Questions for second interview:

- Tell me more about the context of your experiences with biliteracy in the classroom and/or as a reading specialist.

- Reconstruct a typical literacy period. What do you do in your classroom?

- Describe a memorable event in teaching biliteracy.

- Share an anecdote that exemplifies a key value or core belief about teaching bilitearcy.

- Tell me what you do as a bilingual reading specialists.

- Could you talk about your relationship with your students? With other teachers? With parents? With administrators? 
INTERVIEW PROTOCOL \#3

Participant Code:

\section{Understanding Biliteracy: Exploring the Lived Experiences of Bilingual Reading Specialists}

Time of Interview:

Date:

Place:

Interviewer: Tatiana Cevallos

This phenomenological study will explore, through interviews, the lived experiences of bilingual reading specialists in regards to teaching biliteracy.

Please answer the following questions, giving me as many details as possible. Think about your experience teaching biliteracy. Your answers will remain confidential and will be used for research purposes. Participation in this study is voluntary and you may stop at any time.

I want to thank you for your time and honesty during this experience. I would like to read the notes from our previous interview and what you shared with me. Please let me know if I captured what you are trying to share about your experiences teaching biliteracy. Feel free to stop me at any time to change or add anything I may have missed during the transcript and interpretation process.

Follow up questions from data interpreted for third interview here.

Questions for third interview:

- Given what you have shared in our previous conversations, how do you view teaching biliteracy in your life?

- If time and money were not an issue, what and how would you like to further learn about biliteracy?

- You are in front of a panel that includes principals, district administrators, people from TSPC, legislatures and professors. You are talking on behalf of bilingual reading specialists. What would you like them to know?

- What else would you like to add regarding teaching biliteracy? 
APPENDIX D

INFORMED CONSENT FORM 
Informed Consent

You are invited to participate in a research study conducted by Tatiana M. Cevallos from Portland State University, Graduate School of Education. The researcher hopes to explore in depth the lived experiences among Oregon bilingual reading specialists in relation to biliteracy. The research question is "How do bilingual reading specialists understand the phenomena of teaching biliteracy to bilingual students?" This study is conducted in partial fulfillment of the requirements for doctoral degree, and it is under the supervision of Dr. Emily de la Cruz at Portland State University. You were selected as a possible participant in this study because you completed a reading endorsement with courses in English and Spanish and are currently teaching at the elementary level.

If you decide to participate, you will be asked to meet three times with the researcher, for approximately an hour each time, to talk about your experiences teaching biliteracy to bilingual students. The interviews will take place in a span of two months and will be scheduled at times and locations that are convenient for you. The interviews will be audio recorded and the researcher will transcribe the interviews. You may benefit from taking part in this study, as you reflect on your own practice teaching biliteracy. Furthermore, the study will help teacher educators, school districts and state policy makers to better understand the phenomenon of biliteracy and change the way we prepare bilingual teachers in Oregon regarding biliteracy pedagogy.

Any information that is obtained in connection with this study and that can be linked to you or identify you will be kept confidential. This information will be kept confidential by assigning you a pseudonym and keeping the transcripts and other data in a locked cabinet. The transcripts will be destroyed after three years.

Your participation is voluntary. You do not have to take part in this study, and it will not affect your relationship with Portland State University. You may also withdraw from this study at any time without affecting your relationship with Portland State University.

If you have questions or concerns about your participation in this study, contact Tatiana Cevallos at $12753 \mathrm{SW} 68^{\text {th }}$ Ave. Portland, OR 97223. If you have concerns about your rights as a research subject, please contact Research and Strategic Partnerships, Market Center Building $6^{\text {th }}$ floor, Portland State University, (503) 725-4288.

Your signature indicates that you have read and understand the above information and agree to take part in this study. The researcher should provide you with a copy of this form for your own records.

Signature

Date

Print name 